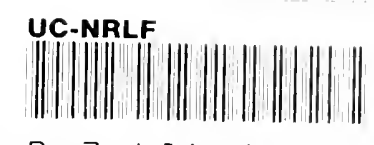

\begin{tabular}{|l}
$\mathrm{P} R$ \\
1119 \\
$\mathrm{~A} 2$
\end{tabular}

ser. 2

no. 118

MAIN

B 3426025 
E 


(I) Ke oullięst Alfithmetics in outrnlish

edited by

Robert Steele

, EARLY ENGLISH TEXT SOCIETY

Extra Series, 118

1922 


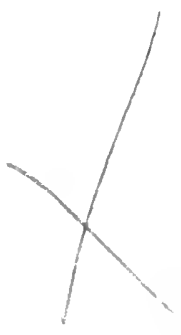

Unaltered Reprint produced with the permission of the Early English Text Society

KRAUS REPRINT CO.

A U.S. Division of Kraus-Thomson Organization Limited

Printed in Germany 


\section{Clye Earticst Aritbumetics in Euglish}

Early Erglish Text Society.

Extra Series, Ho. cxvin.

$19 \propto 2$ (for 1916). 



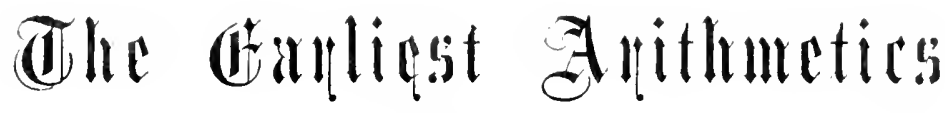 int (otrnlish}

EDITED WITH INTRODUCTION

BY

ROBER'T S'TEELE

LONDON :

PUBLISHED FOR THE EARLY ENGLISH TEXT SOCIETY BY HUMPHREY MILFORD, OXFORD UNIVERSITY PRESS, AMEN CORNER, E.C. 4. 
Extra Series, cxvitr.

Printed in Great Britain by Richaikd Clay \& Suns, Limited, BUNGAY, SUFTOLK. 


\section{IN'TRODUCTION}

Tue number of Euglish arithmeties hefore the sixteenth century is very small. This is hardly to be wonlered at, as no one requiring to use even the simplest operations of the art up to the midcle of the fifteenth century was likely to be ignorant of Latin, in which language there were several treatises in a considerable number of manuseripts, as shown by the quantity of them still in existence. Until modem commerce was fairly well established, few persons required more arithmetic than addition and sultraction, end even in the thirteenth century, scientifie treatises adchessed to advanced students contemplated the likelilioor of their not being able to do simple division. On the other hand, the study of astronomy necessitated, from its earliest days as a science, considerable skill and aceuracy in computation, not only in the calculation of astronomieal tables but in their use, a knowledge of which latter was fairly common from the thirteenth to the sixteenth centuries.

The arithmeties in English known to me are:-

(1) Boll. 790 G. VII. (2653) f. 146-154 (15th c.) ine. "Of alyrym ther be IX figures in numbray ..." A mere unfinished fragment, only getting as far as Duplation.

(2) Camb. Univ. LI. IV. 14 (III.) f. 121-142 (15th e.) ine. "AI maner of thyngis that prosecleth ffro the frist becymnyng . . ."

(3) Fragmentary passages or diagrams in Sloane $213 \mathrm{f} .120-3$ (a fourteenth-century counting board), Egerton 2852 f. 5-13, Harl. 218 f. 147 and

(4) The two MSS. here printed; Eg. 2622 f. 136 and Ashmole 396 f. 48 . All of these, as the language shows, are of the fifteenth century.

The Crafte of Notibnynge is one of a large number of seientific treatises, mostly in Latin, bound $\mathbf{u}_{\mathbf{l}}$ ' together as Egerton MS. 2622 in the British Museum Library. It measures $7^{\prime \prime} \times 5^{\prime \prime}, 29-30$ lines to the page, in a rough hand. The English is N.E. Midlind in dialect. It is a translation and amplification of one of the numerous glosses on the de alyorismo of Alexander de Villa Dei (c. 1220), such as that of 
Thomas of Newmarket contained in the British Musum MS. Reg. 12, L. 1. $\Lambda$ fragment of another translation of the same gloss was printed hy Halliwell in his Rare Mathmatica (1835) p. 29.* It corresponds, as far as p.71,1.2, roughly to p. 3 of our version, and from thence to the end p. 2, 11. 16-40.

The Art of Nombryag is one of the treatises hound up in the Bodleian MS. Ashmole 396. It measures $11 \frac{1}{2} " \times 17_{4}^{3 \prime \prime}$, and is written with thirty-three lines to the page in a fifteenth century hand. It is a translation, rather literal, with amplifications of the de arte $\mathrm{nu}$ meranci attributed to John of Holywood (Sacrobosco) and the translat or had obviously a poor MS. before him. The de arte numerendi was printed in 1488, 1490 (s.n.), 1501, 1503, 1510, 1517, 1521, 1522, 1523,1582 , and by Halliwell separately and in his two editions of Rare Nathematica, 1839 and 1841, and reprinted by Curze in 1897.

Both these tracts are here printed for the first time, but the first having been cirenlated in proof a number of years ago, in an endeavour to discover other manuseripts or parts of manuscripts of it, Dr. David Eugene Smith, misunderstanding the position, printed some pages in a curious transeript with four facsimiles in the Archiv fiir. die Geschichte der Naturwissenseliaften und der Terhuik, 1909, and invited the scientific world to take up the "not unpleasant task" of editing it.

Accomptynge by Counters is reprintel from the 1543 edition of Rolsert Record's Arithmetic, printed by R. Wolfe. It has been reprinted within the last few years by Mr. F. P. Barnard, in his work on Casting Counters. It is the earliest Inglish treatise we have on this variety of the $\Lambda$ bacus (there are Latin ones of the end of the fifteenth century), but there is little doubt in my mind that this method of perforning the simple operations of arithmetic is much older than any of the pen methods. At the end of the treatise there follows a note on merchants' and aulitors' ways of setting down sums, and lastly, a system of digital numeration which seems of great antiquity and almost worle-wide extension.

$\Lambda$ fter the fragment alrealy referred to, I print as an appendix the 'Carmen de Algorismo' of Alexander de Villa Dei in an enlarged and corrected form. It was printed for the first time hy Halliwell in Rara Mathematica, but I have added a number of stanzas from

* Halliwell printed the two sides of his leaf in the wrong order. This and some obvious errors of transeription- 'ferye' for 'ferthe,' 'lest' for 'left,' etc., have not been corrected in the reprint on $\mathrm{pp}$. $70-71$. 
varions manuseripts, selecting various realings on the principle that the verses were made to scan, aided hy the advice of my friend MIr. Vernon Rendall, who is not responsible for the few doubtful lines I have conserved. This poem is at the base of all other treatises ou the sulject in medieval times, but I an unalle to indicate its sources.

\section{The Subject Matter.}

Ancient and medieval writers observed a distinction between the Science and the Art of Arithmetic. The classical treatises on the suliject, those of Enclid among the Greeks and Boethius amongr the Latins, are deroted to the Science of Arithmetic, but it is obvious that eoeval with practical Astronomy the Art of Calenlation nust have existed and have made considerable progress. If early treatises on this art existed at all they must, almost of necessity, have been in Greek, which was the language of science for the lomans as long as Latin civilisation existed. But in their alsence it is safe to say that no involved operations were or could have been carried out by means of the alphabetic notation of the Greeks and Romans. Specinien sums have indeed been constructed by moderus which show its possilility, but it is alssurd to think that men of science, acquainted with Egyptian methods and in possession of the abacus, * were unable to derise methods for its use.

\section{The Pre Medieval Instruments Used in Calcllation.}

The following are known:-

(1) A flat polisher surface or tablets, strewn with sand, on which figures were inseribed with a stylus.

(2) A polished tablet divided longitudinally into nine columns (or more) srouped in threes, with whicl counters were used, either plain or narked with signs denoting the nine numerals, etc.

(3) Tablets or boxes containing nine grooves or wires, in or on which ran beads.

(4) Tablets on which nine (or more) horizontail lines were marketl, each third being marked off.

The only Greek counting board we have is of the fourth class and was discovered at Salamis. It was engraved on a block of marble, and measures 5 feet by $2 \frac{1}{2}$. Its chief part consists of eleven parallel lines, the $3 \mathrm{rd}, 6 \mathrm{th}$, and 9 th being marked with a cross. Another section consists of five parallel lines, and there are three

\footnotetext{
*For kgyptian use see Herodotnx, ii. 36, Plato, de Legibus, VII.
} 
rows of arithmetieal symbols. This board eould only have been used with counters (calculi), preferably unmarked, as in our treatiso of Accomptynge by Cornters.

\section{Classical Roman Methods of Calcutation.}

We have proof of two methods of caleulation in ancient Rome, one by the first method, in which the surface of sand was divided into columns by a stylus or the hand. Counters (calculi, or lapilli), which were kept in boxes (loculi), were used in ealculation, as we learn from Horace's sehoolboys (Sat. 1. vi. 74). For the sand see Persius I. 131, "Nec qui ahaeo numeros et secto in pulsere metas seit risisse," Apul. Apolog. 16 (pulvisculo), Mart. Capella, lib. vii. 3, 4, ete. Cicero says of an expert caleulator "eruditum attigisse pulverem," (de nat. Deorum, ii. 18). Tertullian ealls a teacher of arithmetie "primus numerorum arenarius" (cle Pallio, in fin ). The counters were made of various materials, ivory principally, "Adeo nulla uncia nobis est eboris, ete." (Juv. XI. 131), sometimes of precious metals, "Pro calculis albis et nigris aureos argenteos Labehat denarios" (Pet. Arb. Satyricon, 33).

There are, however, still in existence four Roman comting boards of a kind which does not appear to come into literature. A typical one is of the thirl class. It consists of a nimber of transverse wires, broken at the midlle. On the left hand portion four beads are strung, on the right one (or two). The left hand beads signify units, the right hand one five units. Thus any number up to nine ean be represented. This instrument is in all essentials the same as the Swanpan or Alsacus in use throughout the Far East. The Russian stchota in use throughout Eastern Europe is simpler still. The method of using this system is exactly the same as that of Acromptynge by Counters, the right-hand five bead replacing the counter between the lines.

\section{The poethin Abacus.}

Between elassical times and the tenth century we have little or no guilance as to the art of ealculation. Boethius (fifth century), at the end of lil. II. of his Geometria gives us, a figure of an abacus of the second class with a set of counters arranged within it. It has, however, been contended with great probability that the whole lassage is a tenth century interpolation. As no rules are given for its use, the chief value of the figure is that it gires the signs of the 
nine numbers, known as the Boethian "apices" or "notae" (from whence our word "notation"). To those we shall return later on.

\section{The ABacists.}

It would seen probable that writers on the calenclar like Bede (A.D. 72I) and Helpericus (A.D. 903) were able to perform simple ealculations; though we are unable to guess their methods, and for the most part they were dependent on tables taken from Greek sourees. We have no early medieval treatises on arithmetic, till towards the end of the tenth century we find a revival of the study of science, centring for us round the name of Gerbert, who became Pope as Sylvester II. in 999. His treatise on the use of the Abacus was written (c. 980) to a friend Constantine, and was first printed among the works of Bede in the Basle (1563) elition of his works, I. 159, in a somewhat enlarged form. Another tenth century treatise is that of Abbo of Fleury (c. 988), preserved in several manuscripts. Very few treatises on the use of the Abacus ean be certainly ascribed to the eleventh century, but from the beginning of the twelfth century their numbers increase rapidly, to judge hy those that have been preserved.

The Alaeists used a permanent board usnally divided into twelve columus; the columns were grouped in threes, each column being called an "arcus," and the value of a figure in it represented a tenth of what it would have in the column to the left, as in our arithmetic of position. With this hoard counters or jetons were used, either plain or, more probably, marked with numerical signs, which with the early Abacists were the "apices," though counters from elassieal times were sometimes marked on one side with the digital signs, on the other with Roman numerals. Two ivory dises of this kind from the Hamilton collection may be seen at the British Museum. Gerbert is said by Richer to have made for the purpose of computation a thousand counters of horn; the usual number of a set of counters in the sixteenth and seventeenth centuries was a humdred.

Treatises on the Abacus usually consist of chapters on Numeration explaining the notation, and on the rules for Multiplication and Division. Addition, as far as it required any rules, came naturally under Multiplication, while Subtraction was involved in the process of Division. These rules were all that were needed in Westem Europe in centuries when commerce hardly existed, and astronomy was unpractised, and even they were only required in the preparation 
of the calendar and the assiguments of the royal exchequer. In England, for example, when the hide developed from the normal holding of a household into the unit of taxation, the calculation of the greldage in each shire required a sum in division; as we know from the fact that one of the Abacists proposes the sum: "If 200 marks are levied on the county of lissex, which contains according to Hugh of Bocland 2500 hides, how much does each hide pay?" * Excherquer methods up to the sixteenth eentury were founded on the abacus, though when we have details later on, a different and simpler form was usel.

The great difficulty of the early Abacists, owing to the absence of a figure representing zero, was to place their results and opcrations in the proper columns of the abacus, especially when doing a division sum. The chief differences noticeable in their works are in the methods for this rule. Division was either done direetly or hy means of ditferences between the divisor and the next higher multiple of ten to the divisor. Later Abacists male a distinction between "iron" and "golden" methods of division. The following are eximples taken from a twelfth century treatise. In following the operations it nust be remembered that a figure asterisked represents a comnter taken from the board. A zero is obviously not needed, and the result may be written down in words.

(a) Mulitiplicatiun. $4600 \times 23$.

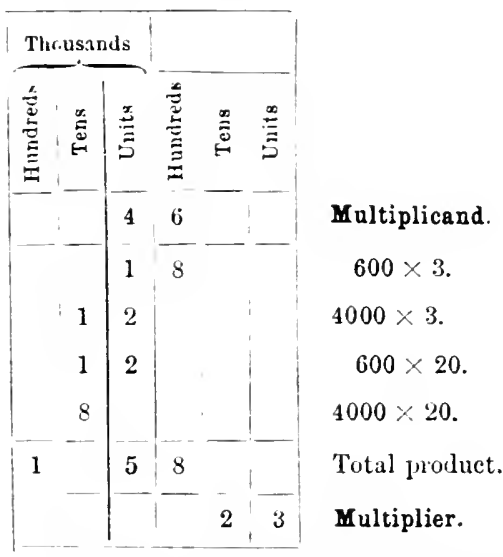

* See on this Dr. Poole, The Exchequer in the Twelfth Century, Chap. 111., and Haskins, Eng. Hist. Lievietr, 27, 101. The hidage of Essex in 1130 was 2364 hides. 
(b) Duision: Dinect. $100,000 \div 20,023$. Here each counter in turn is a separate divisor.

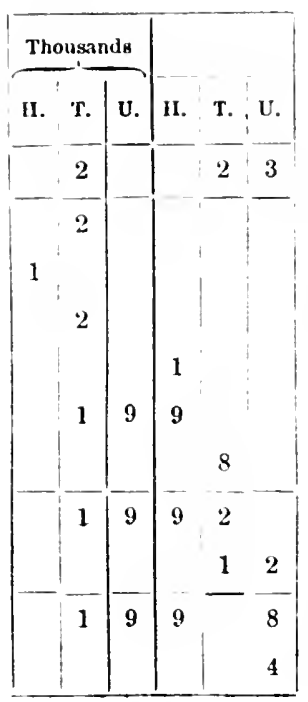

\section{Divisors.}

Place greatest divisor to right of dividend.

Dividend.

Remainder.

Another form of same.

Produet of 1st Quotient and 20.

Remainder.

Product of 1st Quotient and 3.

Final remainder.

Quotient.

(c) Division by Diffenences. $900 \div 8$. Here we divide by $(10-2)$.

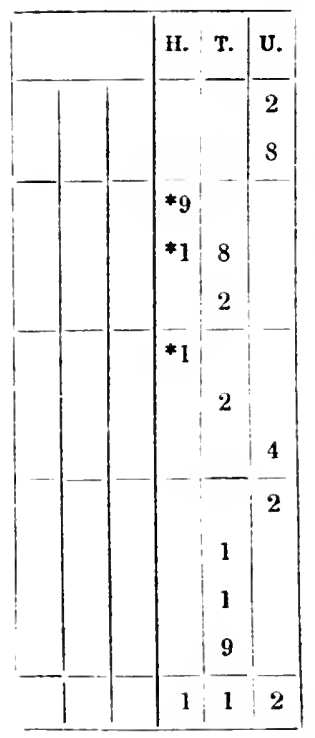

Difference.

Divisor.

Dividend.

Produet of difference by 1st Quotient (9).

Product of difference by 2nd Quotient (1).

Sum of 8 and 2 .

Produet of difference by 3rd Quotient (1).

Product of difference by 4 th Quot. (2). Remainder.

4th Quotient.

3rd Quotient.

2nd Quotient.

1st Quotient.

Quotient. (Total of all fonr.)

- These ligures are removel at the next step. 
Division. $7800 \div 166$.

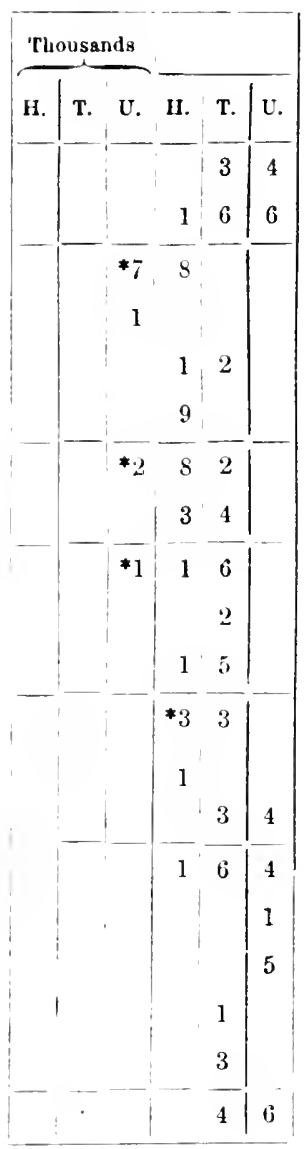

Differences (making 200 trial divisor).

Divisors.

\section{Dividends.}

Remainder of greatest dividend.

Product of 1st difference (4) by 1st Quotient (3).

Product of 2nd difference (3) by 1st Quotient (3).

New dividends.

Proluet of 1st and 2nd difference by 2nd Quotient (1).

New dividends.

Product of 1st difference ly 3rd Quotient (5).

Product of 2nd difference by 3rd Quotient (5).

New dividends.

Remainder of greatest dividend.

Produet of lst and 2nd difference by 4th Quotient (1).

Remainder (less than divisor).

4th Qnotient.

3ril Quotient.

2nd Qnotient.

1st Qnotient.

Quotient.

* These figures are removed at the next step. 
Division, $8000 \div 606$.

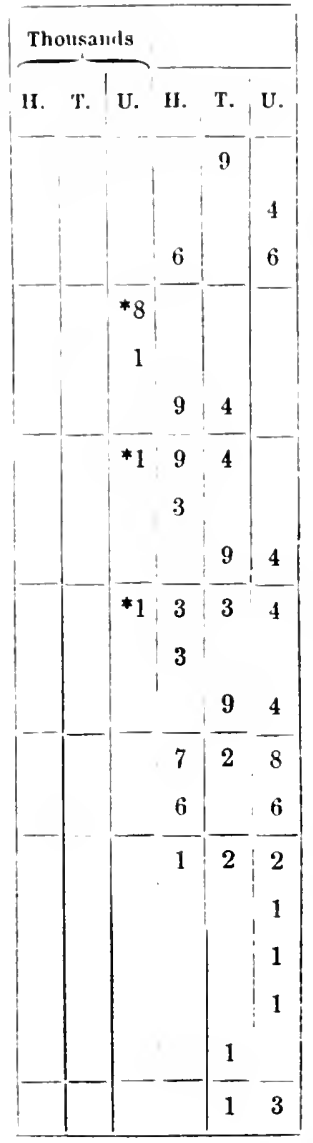

Difference (making 700 trial divisor).

Differenee.

Divisors.

\section{Dividend.}

Remainder of dividend.

Product of difference 1 and 2 with 1st Quotient (1).

New dividends.

Remainder of greatest dividend.

Product of difference 1 and 2 with 2nd Quotient (1).

New dividends.

Remainder of greatest dividend.

Product of difference 1 and 2 with 3rd Quotient (1).

New dividends.

Product of divisors by 4th Quotient (1).

\section{Remainder.}

4tlı Quotient.

3rd Quotient.

2nd Quotient.

1st Quotient.

Quotient.

* These flgures are removed at the next step.

The chief Abacists are Gerbert (tenth century), Abbo, and Hermanuus Contractus (1054), who are credited with the revival of the art, Berneliuus, Gerland, and Radulphus of Laon (twelfth century). We know as English Abacists, Robert, bishop of Hereford, 1095, "abacum et lunarem conpotum et celestium cursum astrorum rimatus," Turchillus Compotista (Thurkil), and throngh him of Guiliehmus R. . . . "the best of living computers," Gislebert, and Simonus de Rotellis (Simon of the liolls). 'They flourished most probably in the 
first quarter of the twelfth century, as Thurkil's treatise deals also with fractions. Walcher of Durham, Thomas of York, and Samson of Worcester are also known as Abacists.

Finally, the term Abacists came to be applied to computers by manual arithmetic. A MS. Algorithm of the thirteenth century (Sl. 3281, f. 6, b), contains the following passage: "Est et alius modus secundum operatores sive practicos, quorum unus appellatur Abacus; et modus ejus est in computando per digitos et junctura manuum, et iste utitur ultra Alpes."

In a composite treatise containing tracts written $\Lambda . D .1157$ and 1208 , on the calendar, the abacus, the manual calendar and the manual abacus, we have a number of the nethods preserved. As an example we give the rule for multiplication (Claud. A. IV., f. 54 vo). "Si numerus multiplicat alium numerum auferatur differentia majoris a minore, et per residuum multiplicetur articulıs, et una differentia per aliam, et summa proveniet." Example, $8 \times 7$. The difference of 8 is 2 , of 7 is 3 , the next article being $10 ; 7-2$ is 5 . $5 \times 10=$ $50 ; 2 \times 3=6.50+6=56$ answer. The rule will hold in such cases as $17 \times 15$ where the article next higher is the same for botl, i.e., 20 ; but in such a case as $17 \times 9$ the difference for each number must be taken from the higher article, $i$. e., the difference of 9 will be 11 .

\section{The Algonists.}

Algorism (augrim, augrym, algram, agram, algorithm), owes its name to the accident that the first arithmetical treatise translated from the Arabic happened to be one written by Al-Khowarazmi in the early ninth century, "de numeris Indorum," beginning in its Latin form "Dixit Algorismi. . . ." The translation, of which only one MS. is known, was made about 1120 by Adelard of Bath, who also wrote on the Abacus and translated with a commentary Euclid from the Arabic. It is probable that another version was made by Gerard of Cremona (1114-1187); the number of important works that were not translated more than once from the Arabic decreases every year with our knowledge of medieval texts. A few lines of this translation, as copied by Halliwell, are given on $\mathrm{P}$. 72, note 2. Another translation still seems to have been made by Johannes Hispalensis.

Algorism is distinguished from Abacist computation by recognising seven rules, Addition, Subtraction, Uuplation, Mediation, Multiplication, Division, and Extraction of Roots, to which were afterwards 
adled Numeration and Progression. It is further distinguished by the use of the zero, which enabled the computer to dispense with the columns of the Abacus. It obviously omploys a boarl with fine sand or wax, and later, as a substitute, paper or parchment; slate and pencil were also used in the fourteenth century, how much earlier is unknown.* Algorism quickly ousted the Abacus methods for all intricate calculations, being simpler and more casily checked: in fact, the astronomical revival of the twelfth and thirteenth centuries would have been impossible without its aid.

The number of Latin Algorisms still in manuscript is comparatively large, but we are here only concerned witl two-an Algorism in prose attributed to Sacrobosco (John of Holywood) in the colophon of a Paris manuseript, though this attribution is no longer regarded as conclusive, and another in verse, most probably by Alexander de Villedieu (Villa Dei). Alexander, who died in 1240, was teaching in Paris in 1209. His verse treatise on the Calendar is dated 1200 , and it is to that period that his Algorism may be attributed; Sacrobosco died in 1256 and quotes the verse Algorism. Several commentaries on Alexander's verse treatise were composed, from one of which our first tractate was translated, and the text itself was from time to time enlarged, sections on proofs and on mental arithmetic being added. We have no indication of the souree on which Alexander drew; it was most likely one of the translations of Al-Khowarasmi, but he has also the Abacists in mind, as shewn by preserving the use of differences in multiplication. His treatise, first printed by Halliwell-Phillipps in his Rara Mathematica, is adapted for use on a board cotered with sand, a method alnost universal in the thirteenth century, as some passages in the algorism of that period already quoted show: "Est et alius modus qui utitur apud Indos, et doctor hujusmodi ipsos "erat quidem nomine Algus. Et molus suus erat in computando per quasdam figuras scribendo in pulvere. . . ." "Si voluerimus depingere in pulvere predictos digitos secundum consuetudinem algorismi ..." "et sciendum est quod in nullo loco minutorum sive secundorum . . . in pulvere debent scribi plusquam sexaginta."

\section{Moderi Arithmetic.}

Modern Arithmetic begins with Leonardi Filonacci's treatise "de Abaco," written in 1202 and re-written in 1228. It is modem

* Slates are mentioned by Chaucer, and soon after (1410) Prosdocimo de Beldamandi speaks of the use of a "lapis" for making notes on by calculators. 
wather in the range of its problems and the methods of altack than in mere methods of calculation, which are of its periorl. Its sole interest as regards the present work is that Lconardi makes use of the digital signs described in Recorl's treatise on The arte of nombrynge by the hand in mental arithmetic, calling it "modus Indorum." Lconardo also introduces the method of proof by "casting out the nines."

\section{Digital Arithmetic.}

The method of indicating numbers by means of the fingers is of considerable age. The British Museum possesses two ivory counters marked on one side by carelessly scratched Roman numerals IIIV and VIIII, and on the other by carefully cngraved digital sigus for 8 and 9 . Sixteen scems to have been the number of a complete set. These counters were either used in games or for the counting board, and the Muscum ones, coming from the Hamilton collection, are undoubtedly not later than the first contury. Frohner has published in the Zeitschrift des Münchener Alterthumsrereins a set, almost complete, of them with a Byzantine treatise; a Latin treatise is printed among Bede's works. The use of this method is universal through the East, and a variety of it is found among many of the native races in Africa. In medieval Europe it was almost restricted to Italy and the Mediterranean basin, and in the treatise already quoted (Sloane 3281) it is even called the Abacus, perhaps a memory of Fibonacci's work.

Nethods of calculation by means of these signs undoubtedly have existed, but they were too involved and liable to error to be much used.

\section{The Use of "Arabic" Figures.}

It may now be regarded as proved by Bubnov that our present numerals are derived from Greek sources through the so-called Boethian "apices," which are first found in late tenth century manuscripts. That they were not derived directly from the Arabic secms certain from the different shapes of somc of the numerals, especially the 0, which stands for 5 in Arabic. Another Greek form existed, which was introduced into Europe by John of Basingstoke in the thirteenth century, and is figured by Matthew Paris (V. 285); but this form had no success. The date of the introduction of the zero has been hotly clebated, but it seems obrious that the twelfth century Latin translators from the Arabic were 
perfectly well acquainted with the system they met in their Arabie text, while the earliest astronomieal tables of the thirteenth eentury I have seen use numbers of Emopean and not Arabic origin. The fact that Latin writers had a convenient way of writing hundreds and thousands without any cyphers probably delayed the general use of the Arabic notation. Dr. Hill has published a very complete survey of the various forms of numerals in Europe. They began to be common at the middle of the thirteenth century and a very interesting set of family notes concerning births in a British Museum manuseript, Harl. 4350 shows their extension. The first is dated Mij. lviii., the second Mij. Ixi., the third Mij. 63 , the fourth 1264 , and the fifth 1266. Another example is given in a set of astronomical tables for 1269 in a manuscript of Roger Bacon's works, where the scribe began to write MICC6. and crossed ont the figures, substituting the "Arabie" form.

\section{The Counting Board.}

'The treatise on pp. 52-65 is the only one in English known on the subject. It describes a method of calculation whieh, with slight nodifieations, is current in Russia, China, and Japau, to-day, though it went out of use in Western Europe by the seventeenth eentury. In Germany the method is called "Algorithmus Linealis," and there are several editions of a tract under this name (with a diagram of the counting board), printed at Leipsic at the end of the fifteenth century and the beginning of the sixteenth. They give the nine rules, but "Capitulum de radieum extractiono ad algoritmum integrorum reservato, cujus species per eiffrales figuras ostenduntur uli ait plenum de hac tractabitur." The invention of the art is there attributel to Aplunlegins the philosopher.

The advantige of the counting board, whether permanent or construeted by chalking parallel lines on a table, as shown in some sixteenth-century woodcuts, is that only five counters are needed to indieate the number nine, counters on the lines representing units, and those in the spaces above representing five times those. on the line below. The Russian abacus, the "tchatui" or "stehota" has ten beads on the line; the Chinese and Japanese "Swanpan" economises by dividing the line into two parts, the beads on one side representing five times the value of those on the other. The "Swanpan" has usually many more lines than the "stchota," allowing for more extended calculations, see Tylor, Anthropology (1892), p. 314. 
Record's treatise also mentions another method of counter notation (p. 64) "merchants' casting" and "auditors' casting." These were adapted for the usual English method of reckoning numbers up to 200 by scores. This method seems to have been used in the Exchequer. A counting board for merchants' use is printed by Halliwell in Rara Mathematica (p. 72) from Sloane MS. 213, and two others are figured in Egerton 2622 f. 82 and f. 83 . The latter is said to be "novus modus computandi secundum inventionem Magistri Thome 'I'horleby," and is in principle, the same as the "Swanpan."

The Exchequer table is described in the Dialogus de Scaccario (Oxford, 1902), p. 38 . 


\section{Tye Errliest Aritlmutics int Englisly.}





\section{The cinafte of llombrunge.}

Egerton 2622.

1 Ec algorismus ars presens dicitur; in qua

1 leaff $136 a$. Talib $\iota$ : indor $u m$ fruim $u r$ bis qui $/ q u e$ figuris.

This boke is called pe boke of algorym, or Angrym after lewder a derivation 4 vse. And pis boke tretys pe Craft of Nombryng, pe quyeh erafte of Algorisin. is ealled also Algorym. Ther was a kyng of Inde, pe quich heyth Algor, \& he made pis craft. And after his name he called hit algorym; or els anop'r cause is quy it is called Algorym, for pe 8 latyn word of hit $\mathrm{s}$. Algurismus comes of Alros, grece, 'luid est Another ars, latine, eraft onl enclis, and rides, quid est mumerus, latine, A due word. nombur on englys, inde dicitur Algorismus per adlicionem huins sillabe mes \& subtraccionem d \& e, quasi ars numerandi. Tf fforther-

12 more ze most vudirstonde pat in pis craft ben vid teen figurys, as here lene writen for ensampul, $\phi 987654321$. T Expone pe tow versus afore: this present eraft ys ealled Algorismus, in pe quych we vse teen signys of Inde. Questio. T Why ten fyguris 16 of Inde? Sulueio. for as I hane sayd afore pai were fonde fyrst in Inde of a kyngro of pat Cuntre, pat was callet $\Lambda$ lgor.

If Prima significat unu $n$; duo vero secunda:

- Tercia significat tria; sic procede sinistre.

\section{Donec ad extrema $/$ venias, que cifra vocatur.}

\section{Capitulum primum de significacione figurarum.}

In pis verse is notitile pe signifieacion of pese figuris. Ant pus expone the verse. be first signifiyth one, $p$ secunde signiffiyth 2 lear $136 b$. 24 tweyne, pe thrycl signifiyth thre, \& the fourte signifiyth 4 . And The meaning so forthe towarde pe lyft syde of pe tabul or of pe boke pat pe the figures. figures bene writene in, til pat pou come to the last figure, pat is 
called a cifre. M Questio. In quych syde sittes pe first figure? Solucio, forsothe loke quich figure is first in pe ryzt side of pe bok or of pe tabul, \& pat same is pe first figure, for pou schal write which figure bakeward, as here, 3. 2. 6. 4. 1. 2. 5. The tigure of 5. was first is reat first. write, $\&$ he is pe first, for he sittes on pe rizt. syde. And the figure of 3 is last. I Neuer-pe-les wen he says I Prima significut vnum \&c., pat is to say, pe first betokenes one, pe secunde. 2. \& fore-per-more, he vndirstondes nozt of pe first figure of euecy rew. I But he vndirstondes pe first figure pat is in pe nombur of pe forsayd teen figuris, pe quych is one of pese. 1. And pe seeunde 2 . \& so fortl.

verous [ln margin].

Expositio [il margiil].

An explana. tion of the notation.

1 leas 137 a.

Tा Quelibet illarum si primo limite ponas,

Tा Simpliciter se significat: si vero secundo, Se decies: sursu $m$ procedas multiplicando.

T Nanque figura seque $\iota$ s quanuis signat decies pl $u s$.

Tा Ipsa locata loco quam significat pertinente.

I Expone fis verse pus. Euery of pese figuris bitokens hym selfe $\&$ no more, yf he stoude in pe first place of pe rewele / this worde Simpliciter in pat verse it is no more to say but pat, $\&$ no more. If If it stoncle in the secunle place of pe rewle, he 20 betokens tene tymes hym selfe, as pis figure 2 here 20 tokens ten tyme hym selfe, ' pat is twenty, for he hym selfe betokenes tweyne, \& ten tymes twene is twenty. And for he stondis on pe lyft side $\&$ in pe secunde place, he betokens ten tyme hym 24 selfe. And so go forth. If ffor every figure, \& he stonde aftur a-noper toward the lyft side, he schal betokene ten tymes as mich more as he sehul betoken $\&$ he stode in pe place pere pat pe An example: figure a-fore hym stondes. loc an ensampulle. 9. 6. 3. 4. pe 28 units, figure of 4 . put hase pis sehape $t$. betokens bot hymselfe, for he stondes in pe first place. The figure of 3 . pit hase pis schape tens, $\quad 3$. betokens ten tymes more pen he schuld \& he stode pere fat pe figure of 4 . stondes, pat is thretty. The figure of 6 , put liase 32 pis sehape $\mathfrak{G}$, betokens ten tymes more fan he schuld \& he stode pere as pe figure of 3. stondes, for pore he schuld tokyne bot hundrels, sexty, \& now he betokens ten tymes more, pat is sex humdryth. The figure of 9. pat hase pis schape 9. betokens ten tymes more 36 pane he schnld \& he stode in pe place pere pe figure of sex stoncles, for pen he schuld betoken to 9 . hundryth, and in pe place fere he thousands. stondes now he betokens 9 . pousande. Al pe hole nombur is 9 thousande sex hundryth \& foure \& thretty. If fforthẹrmore, when 40 
pon sehalt rede a nombur of figure, pou selialt loggne at pe last Inow to read figure in the lyft sile, \& relle so forth to pe rizt sicle as here 9.6 .

3. 4. Thou sehal beryn to rede at pe figme of $9 . \&$ rede forth

4 pus, 9. '1thousand sex hundryth thritty \& foure. But when pou 1 leaf 1:7b. scialle write, pon sehalt lee-gymne to write at pe ryzt side.

\section{Nil cifra siguificat serl dat signare sequenti.}

Expone pis verse. A cifre tokens nozt, bot he makes pe figure The meaning $S$ to betoken pat comes aftur hym more pan he schuld \& he were the cipher. away, as pus l $\phi$. liere pe figure of one tokens ten, $\&$ yf pe eifre were away ${ }^{2} \&$ no figure by-fore hym he sehuld token bot one, for pan he schuld stonde in pe first place. T And pe eifre tokens 12 notlyng hym selfe. for al pe nombur of pe ylke too figure.s is bot ten. I Questio. Why says he pat a eifre makys a figure to signifye (tyf) more \&e. I I speke for pis worle signifieatyf, ffor sothe it may happe aftur a eifre schull come a-nopur cilie, as pus $2 \phi \phi$. And 16 zet pe secunde cifre shuld token neuer pe more exeep he schuld kepe pe orter of pe plice. and a eifre is no figure signifieatyf.

I Q $u a \mathrm{~m}$ precedentes plus ultima significabit /

Lixpone pis verse pus. be last figure schal token more pan alle Thie last $_{\text {figure means }}$ 20 pe oper afore, thonjt pere were a humlryth thonsant figures afore, more melang all as pus, 16798. pe last figure pat is 1 . betokens ten tholsant. Antl siuce it it of alle pe oper figures hen bot betokene bot sex thousant senyne value. humbryth nynty \& 8 . T And ten thousant is more pen alle pat 24 nombur, $r$ go fe last figure tokens more pan all pe nombur afore.

${ }^{3}$ I Post piedicta scias breuiter quod tres numerornu Distincte species sunt; nam quidam digiti sunt; Articuli quidam; quidam qurupe compositi sunt.

T Capit $u l n \mathrm{~m} 2^{\mathrm{m}}$ de triplice divisione numeror $u m$.

T The anetor of pis tretis leprertys pis worde a nombur into 3 partes. Some nombur is called digitus latine, a digit in englys. nigit. Somne nombur is called artieulus latine. An Artienl in englys. Articles. 32 Some nombur is called a composyt in englys. If Expone pis verse. Composites. know pou aftur fe forsayd rewles pat I sayd afore, pat pere ben thre spices of nombur. Oone is a digit, Anofer is an Articul, \& pe toper. a Composyt. versis.

36 I Sunt digiti numeri qui citra denarian sunt.

T lleve lue telles ywat is a digit, Expone versus sic. Nomlun's What are digitus bene alle nomblus pat hen with-inne ten, as nylie, 8. 7.6.5. 4. 3. ‥ 1 . 


\section{Tा Articupli decupli degito'un; ; compositi s $/ n t$ Illi qui constant ex articulis degitisque.}

T Jere he telles what is a composyt and what is ane articul. what are Expone sic versus. If Articulis ben ${ }^{1}$ alle fat may be deuilyt in- 4 articles. to nomburs of ten \& nothynge leue ouer, as twenty, thretty, fourty, a hundryth, a thousand, \& such oper, ffor twenty may be deprertyt in-to 2 nomburs of ten, fforty in to foure nomlurs of ten, \& so forth.

2 lenf $138 b$. ilyat numbers a) conts. posites.

How to wije a number.

if it is a digit ;

if it is a composite.

leaf $139 a$ How to read it.

${ }^{2}$ Compositys ben nomburs pat bene componyt of a digyt \& of an articulle as fouretene, fyftene, sextene, \& such oper. ffortene is componyd of foure pat is a ligit \& of ten pat is an articulle. ffiftene is componyd of $5 \&$ ten, \& so of all oper, what pat pai ben. Short-lych euery nombur pat be-gynnes with a digit \& emlyth in a 12 articulle is a composyt, as fortene lygremunge by four pat is a digit, \& emles in ten.

\section{Tा Ergo, proposito numero tibi scriber $\rho$, primo}

Respicias quid sit numertus; si digitus sit

Primo scribe loco digitum, si compositus sit

Primo scribe loco digitum post articulu $m$; sic.

Th here he telles how pou schalt wyrch whan pou schalt write a nombur. Expone versum sie, \& fac inxta exponentis sentenciam; 20 whan pru hast a nombur to write, loke fyrst what maner nombur it ys put pou schalt write, whether it be a ligit or a composit or an Articul. If If he be a digit, write a digit, as yf it he senen, write senen \& write pat digit in pe first place toward pe ryght sille. If it $\mathbf{2 4}$ be a composyt, write pe digit of pe composit in pe first place $\&$ write pe articul of pat ligit in pe secunde place next toward pe ly ft sile. As yf pou schal write sex \& twenty. write pe ligit of pe nomlun in pe first place pat is sex, and write pe articul next aftur 28 pat is twenty, as pus 26. I,ut whan pon schalt sowne or speke ${ }^{3}$ or rede an Composyt pou schalt first sowne pe articul \& aftur pe digit, as pou seyst by pe comyne speche, bex \& twenty \& nonzt twenty \& sex. versus.

T Articul $u s$ si sit, in primo limite cifram, Articulum vero reliquis inscribe figuris.

How towrite Tl Jere he tells how pou schal write when pe nombre pat pou Articles : hase to write is an Articul. Expone versus sic \& filc secuntum 36 sentenciam. Ife pe nombur prit pou hast write be an Articul, write tens, first a cifre \& aft $m$, pe cifer write an $\Lambda$ rticulle pus. $2 \phi$. fforthermore pou schalt vmlirstonle yf pou hane an Articul, loke how 
mych he is, yf he be with-yuno an hunelyth, pou schalt write bot one cifre, afore, as here $.9 \phi$. If pe articulle be by hym-silfe $\&$ be hundreas, an humdrid enene, pen schal pou wite. 1 . \& 2 cifers afore, pat he 4 may stonde in pe thryel place, for euery figne in pe thryel place schal token a hundriel tymes hym selfe. If pe articul be a thousant thousants, or thonsandes ${ }^{1}$ and he stonde by lym selfe, write afor 3 cifers $\&$ so forp of al oper.

Tा Quolibet in numcro, si par sit prima figara,

Par erit \& to $/$ m, quicquid sibi contimnatu";

Impa' si fuerit, totu $/ \prime$ tu $/$ c fiet et impar.

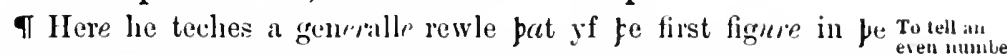
12 rewle of figures token a nombur pat is cnene al pat nombur of fign'ys in pat rewle schal be enene, as liere pou may see 6. 7. 3. 5. 4. Computa \& proba. T If pe first ${ }^{2}$ ligure token an nombur pat is oule, 2 leaf 139 o. alle pat nombur in pat rewle schalle be ode, as here 567867 . or an oild. 16 Computa \& proba. versus.

T Septe su sut partes, non plures, istius artis;

T Addere, subtraher", duplar', dimidiare,

Sextaque diuidere, sell qui /ta multiplicare;

Radice $m$ extrahere po's septi $/$ a dicitur esse.

T Here telles pat per ben . $\boldsymbol{\tau}$. spices or partes of pis craft. The The seven first is called aldicion, pe secunde is called subtraccion. The thryal is called duplacion. The 4. is called dimyelicioñ. 'The 5. is called 24 multiplicacion. The 6 is called diuision. The $\tau$. is called extraccion of pe Rote. What all pese spices bene hit schalle be tolde singillatim in liere caputule.

\section{Subt, ${ }^{\prime}$ his aut addis a dext, is vel mediabis :}

28 Thou schal be-gyme in pe ryglit sicle of pe boke or of a tabul. Adu, sub. loke were pon wul be-gyme to write latyn or englys in a boke, \& hatre, from prit schalle be called pe lyft side of the boke, pat pou writest toward pat side schal be called pe ryght side of pe boke. Tersus.

\section{A leua dupla, diuide, multiplica.}

Here he telles pe in quych side of pe boke or of pe tabul pou schalle be-gyne to wgrch duplacion, diuision, and multiplicacion. Thou schal begyne to woreh in pe lyft sille of pe boke or of pe sultiply or 36 tabnl, but yn what wyse pom schal wyeh. in hym dicetur singil- livide to right. latim in sequentibus: capitulis et de vtilitate cui $u$ liluet artis \&

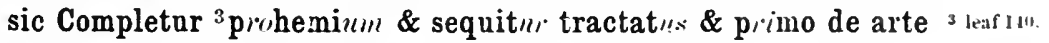
addicionis que prima ars est in ordine.

\footnotetext{
'In MS. 'thansaniles.'
} 


\section{A $\begin{aligned} & \text { ddere si nnmero num rum vis, ordine tali } \\ & \text { Incipe; scribe duas primo series numeror } u m\end{aligned}$ Primam sub prima recte ponendo figuram, Et sic de reliquis facias, si sint tibi plures.}

Four things must be known:

what it is;

liow many rows of figures;

low many cases;

what is its result.

1 leaf $140 \mathrm{~b}$. How to set down the sum.

I Here by-gymes pe craft of Addicion. In pis craft pon most knowe foure thynges. If Fyrst pou most know what is addieion. Next pou most know how mony rewles of figurys pou most haue. I Next pou most know how mony diners easys happes in pis craft 8 of aldicion. If And next qwat is pe profet of pis craft. If As for pe first pou most know pat addicion is a castyng to-ged $u l^{\circ}$ of twoo nomburys in-to one nombre. As yf I aske qwat is twene \& thre. pou wyl east pese twene nombres to-ged $u$. \& say pat it is fyue. 12 If As for pe secunde pou most kuow pat pou sehalle haue tweyne rewes of figures, one vndur a-nother, as here pou mayst se. 1234 I As for pe thryd pou most know pat there ben foure diuerse 2168. cases. As for pe forthe pou most know pat pe profet of pis craft is 16 to telle what is pe hole nombur pat comes of diuerse nomburis. Now as to pe texte of oure verse, he teches there how pou schal woreh in pis eraft. If He says yf pou wilt cast one nombur to anoper nombur, pou most by-gynne on pis wyse. If ffyrst write 20 ${ }^{3}$ two rewes of figuris \& nombris so pat pou write pe first figure of pe hyer nombur enene vndir the first figure of pe nether nombur, And pe secunde of pe nether nombur euene vnd $i$, pe seeunde of pe hyer, \& so forthe of euery figure of both pe rewes as pou mayst se 123.

If Inde duas adde primas hac condicione:

\section{Si digitus crescat ex addicione prior $u m$;}

Primo scribe loco digitum, quicu $n$ que sit ille.

If Here he teches what pou schalt do when pou hast write too 28 Add the first liswes of figuris on vuder an-oper, as I sayd be-fore. T He sinys pou figures; selalt take pe first figure of pe heyer nombre $\&$ pe fyrst figure of pe neper nombre, \& cast hem to-geder vp-on pis condicion. Thou schal loke qweper pe nomber pat comys pere-of be a digit or no. 32

rub out the top fi:ure;

write tlie result in ils place.
If If he be a dirit pou sehalt do away pe first figure of pe hyer nombre, and write pere in his stede pat he stode Inne pe digit, pat eomes of pe ylle 2 figures, \& so wrich forth on oper figures yf pere he ony moo, til pou come to pe ende towarl pe lyft side. And 36 lede pe nether figure stonde still euer-more til pul haue ydo. ffor pere-by prom schal wyte wheper fou hast done wel or no, as I sehal t.ll pe afterward in po ende of pis Chapter. TI And loke allgate

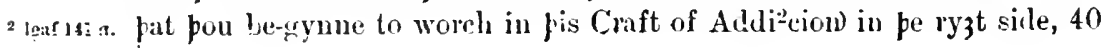


here is an ensampul of pis case 1234 Caste 2 to four id pat wel be llere in an sex, lo away 4. 4 write in pe $214 \%$ same place pe figne of sex. T Anul lete pe figure of 2 in pe nether rewo stonde stil. When

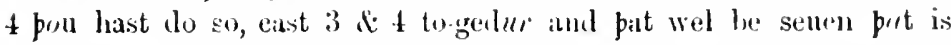
a digit. Do away bo 3 , \& set pre senen), and lete pe neper figure stmole still, \& so worel forth hak warl til pou hist ydo all to-reder.

\section{Et si compositus, in limite scribe sequeute}

3

\section{Articulum, primo digitum; quice sic iubet ordo.}

THere is fe secmule ease pot may happe in pis craft. Anl po

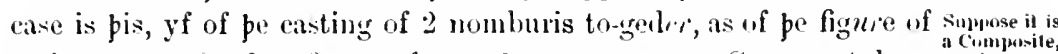

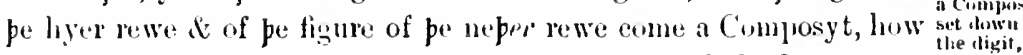
12 schalt pou woreh. pus pon sehalt worch. Thou shalt do away pe imuleiry figne of pe hyer nomlwe pat was east to pe figure of pe mepe. nomber. I And write pree be ligit of pe Composyt. Anl set pe articul of pe composit next after pe cligit in pe same rewe, yof pere

16 be $n 0$ mo figures after. But $\mathrm{gf}$ pror le mo figuris after pat digit. And pere he selatl be rekend for lyim selfe. And when pou sehalt alle poit ylke tigure pat berys pe articullo alter his hed to pe figure vnder hyu, pou selialt cast pat artiun to pe figm" prot hase hym oner

20 his hed, de pere pat Articul selial token hym selfe. Jo an Ensam- Here isan pull ${ }^{1}$ of all 326 . Cast 6 to 6 , 4 pereof wil arise twelue. do away sxample. pe hyer $6^{216} \&$ write pree 2 , pat is pe ligit of pis composit. Aul pen write pe articulle pat is ten ow' pe tiguris heal of twene 24 as pus $\begin{gathered}1 \\ 322\end{gathered}$ Now cast pe artieulle pret stamlus vpon be figleis of twene 216. heal to pe same figure, i reken pat articul bot for one, aml pin pore wil arise thre. ban cast pat thre to pe neper figrue, pat is on", it pat wul be foure. do away pe figme of 3 , amb write 28 pere a figme of fonre. and lete pe neper fignue stomle stil, $\mathbb{1}$ pan worch forth. verteressus.

I Articulus si sit, in pirmo limite cifram,

If Articula $/ \prime$ veio reliquis inscribe figuris, Vel per se scribas si nulla figura sequat $m$.

II Here he puittes pe thryile case of pe craft of Aldieion. \& pe case is pis. $y^{f}$ of Alllieioun of 2 figuris a-ryse an Articulle, low suppose it is

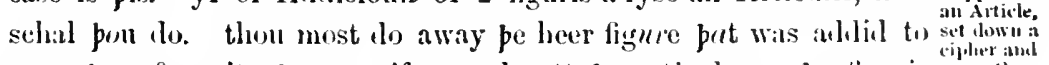
36 pe neper, \& write pere a cifre, and sett pe artieuls on pe tiguris carry the hede, yf put prire come ony after. Aml wyreh pam as I haue tolde pe in pe secumele casi. An ensampull 25. Cast 5 to 5 , pat wylle be ten. now do away pe hyer 5, \& ${ }^{15}$ write pert a cifer. Aml 40 sette ten rpon pe figuris heel of 2 . And reken it but for on pus. Io 


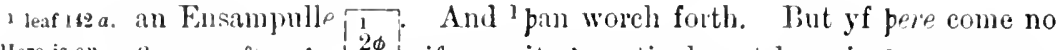

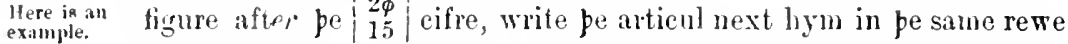
as here 5. cast 5 to 5 , and it wel be ten. do away 5 . pat is pe hier 5.5 anl write pere a cifre, \& write afte hym pe articul as 4 pus $\begin{gathered}1 \phi \\ 5\end{gathered}$ Anl pau pou hast done.

\section{Si tibi cifra superueniens occurrerit, illam}

Dele sup posita $"$; fac illic scribe figura $m$, Postea procedas reliquas addendo figuras.

What in do when you lave a cipher cifer in be hier rewe, how bon selial do. pus pon schalt do. do in the top row.

An example of all the difficulties. away pe eifer, \& sett prie pe digit pat eomes of pe addicioun as pus 12 $1 \phi \phi 54$. In pis ensampul ben alle pe foure cases. Cast 3 to foure, 1 ir 43 pat wol be senen. do away 4 . \& write pere senen ; pan east 4 to pe figure of 8 . pat wel be 12 . do away 8 , \& sett pere 2. pat is a digit, and sette pe artieul of pe composit, fat is ten, vpon fe cifers 16 hel, \& reken it for hym selfe fat is on. pan cast one to a cifer, \& hit wulle be but on, for nozt \& on makes lut one. pan cast 7 . pret stondes vuder pat on to hym, \& pat wel be 8 . do away pe cifer \& pat 1. \& sette pere 8 . pan go forthe:more. cast pe oper 7 to pe cifer 20 pat stonles our, hym. pit wul be bot senen, for pe cifer betokens

${ }^{2}$ leaf 142 b. nozt. do away fe eifer \& sette pure senen, ${ }^{2} \&$ pen go forpermore \& east 1 to 1 , \& pat wel be 2 . Ho away pe hier $1, \&$ sette pere 2. pan last pou do. Anel yf pou laue wel yolo pis nomber pat is sett 24 here-after wel be pe nomber pat sclalle aryse of alle pe aldicions as here 27827 . T Seyuitur alia species.

\section{1 numero numerum si sit tibi demere cura 1 Scribe figurarum series, st in addicione.}

Four tlings to know abuts sub. traction:

the first; the second;

the thinl;

llie fourilı.
T This is pe Chapter of sultraccion, in the quych pou most know foure nessessary thynges. the first what is subtraccion. pe secunde is low mony nombers pou most hane to subtriccion, the thryd is how mony maners of cases pere may happe in pis chaft of 32 subtraccionl. The fourte is ywat is pe profet of pis craft. I As for pe first, fou most know prat subtraccion) is drawynge of one nowmler cute of anoper nomber. As for pe scemcle, pou most knowe prat fru most hane two rewes of figuris one vuder anoper, as 36 pon allyst in adlicioni. As for pe thryd, pou moyst kitow prot funre mane of linerse easis mai hapue in pis craft. T As for pe fomrt, pom most know pat pe profet of pis eraft is wheme pou hasse taken pe lase nomber out of pe more to telle what pere lenes oner 40 
prit. \& pou most be-gynne to wyreh in fis craft in pe ryght side of pe boke, as pou diulyst in aldiciou. Veisus.

I Maiori numpio num $\mathbf{u} m$ suppone minorem,

वा Siue pari numfro supponatı numeus par.

1 9 Here he telles pat pe hier nomber most be more pen pe neper, ' leaf 143a. or els euen as mych. lut he may not be lasse. And pe ease is preater pis, pou schalt drawe pe nepec nomber out of pe hyer, \& pou mayst anmber

8 not do prit yf po hier nomber were lasse pin patt. ffor pon mayst not less.

draw sex out of 2. Sint pon mast draw 2 out of sex. And pon maiste draw twene ont of twene, for pou schal lene nozt of pe hier twene vule versus.

Tा Postea si possis a prima subt, (che prima $\prime \prime$

Scribens quod remanet.

Here is pe first case jut of sulbtraceion), \& he says pou schalt The first case begyme in pe ryght side, \& driw pe first figure of pe nepry rewe of sul.

16 out of pe first figure of pe hier rewe. qwether pe hier figne be more pen pe neper, or enen as myeh. And pat is notified in pe vers when he says "Si possis." Whan pou has pus yilo, do away pe hiest figure \& sett pore pat lenes of pe subtraccion, lo an Ensampulle Here is an 20 234: draw 2 out of 4 . pan lenes 2 . do away $4 \&$ write pere 2 , \& 122 latte pe neper figure stomle stille, \& so go for-by oper figuris till pou come to pe eule, pan hast pou do.

\section{Cifram si nil remanebit.}

24 Tा Here he puttes pe secumle case, $\&$ hit is pis. yf it lappe put pun a cipher qwen pou hast draw on neper figme out of a hier, \& peje lene nozt remains. aftei be subtraceion', pus '2 pou schalt do. pon schalle do away pe hier 2 tear usu. figrre \& write pree a cifer, as lo an Ensampull ra. Take foure llere is an 28 out of foure pan leus nozt. perefore do away l24 pe hier $4 \&$ set pere a cifer, pan take 2 ont of 2 , pan lewes nozt. do away pe hicr 2 , \& set perp a cifer, and so woreh whare so ene, pis hiple.

Sed si non possis a prima dem "re prima"'

Precedens vnu/n de limite deme sequente,

Quod demptum pro denario reputabis ab illo

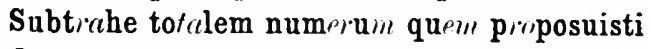

Quo facto scribe super quicquid remanebit.

36 Here he puttes pe thryd ease, pe yuyeh is pis. yf it happe pat suppose you pe neper figmre be more pen pe hier figure pat lie schalle be lraw ont caunut lower of low selalle pou do. pus pour sigure irum

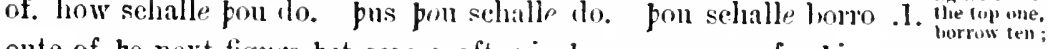
onte of pe next figure pat comes aftor in pe same lrowe, for pis case 40 may never haple but yf pere come tigures after. pan pon schalt solt 
pat on ouer pe hier figmes: hed, of the ruych pon woldist y-traw oute pe neypor figure yf pon haddyst y-myzt. Whane pon hase take the
lower number lower number
Irom tell; add the alile to pe figrtire on whos hed pat.1. stode. And pen pon schalle inswer to do away alle pat, \& sett pere alle that arisys of the allicionil of pe number. ylke 2 figuris. Alid if yt thappe pat pe figure of pe 'fuych pron

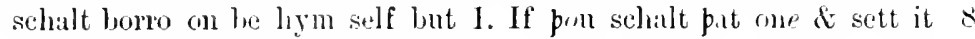
vplon' pe ofe' figuris: hed, and sett in pat 1. place a cifer, yf prese Example. come mony figmes after. Io an Ensampinl. 2122? talie 4 out of 2 . it wyl not he, perfore borro on of fe next 1134 figure, pat is ?. and sett pat oure pe herl of pe fyrst 2. . ' rekene it for tem. aml pere pe 12 sucuncle stondes write 1. for pou tokest on out of hym. pan talke pe neper figure, pat is 4 , out of ten. And pen leues 6 . cast to 6 pe fingue of pat 2 pat storle mile pe hedde of 1. pat was borwerl it rekened for ten, and pat wylle he 8 . do away pat $6 \&$ pat 2 , \& 16

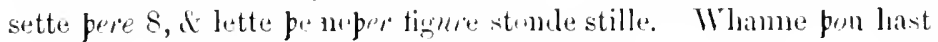

How to

"l'ay lack" the frorruned tell.

A virly hislal citse is put. lo jus, go to pe next figure fat is now bot 1. but first $y^{t}$ was 2 , it pereofowas borred 1. pan taks ont of pat pe figne muld hym, pat

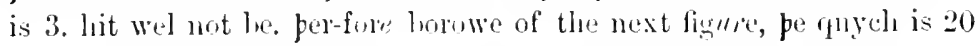
bot 1. Also take \& sett lym onr pe helle of pe firme pat pon wollest hane y-ulaw oute of pe mether fignre, pe anych was 3. it pon my 3 t not, \& rekene fat borwed 1 for ten it sett in pe same

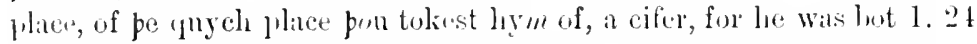
Whamme fou hast pus yedo, take ont of pat 1 . put is relient for ten,

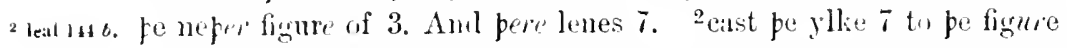
pat had pe ylke ten roon his heel, pe ruych figure was 1 , if pat wol be 8. pan to away pat 1 and pat $\bar{c}$, \& write fere 8 . \& pan wyreh 28 forth in oper figuris til pou come to pe ende, d pan foul hast pe do. Yersus.

- Facque nonenarios de cifris, cu // remeabis

- 0ccurant si forte cifre; dum demps" is vnum

- Postea pi,cedas reliquas deme»do figuras.

- Iere he puttris pe foute case, pe cuych is pis, yf it haple pat

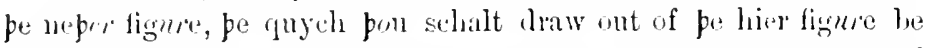
more fion pe liver figur one hym, \& pe next ligure of two or of 36 three or of foure, or how mony prop le liy cifers, low wold pos do. bon wost wel fou must mole burow, if poll mayst not borow of pe: cifers, for pai laue nuzt fat pai may leme or spare ligo" how

$$
\text { "L'eraps "so." }
$$


wollest pou do. Certayin pus most pon do, pou most borow on of pe mext fignre signiticatyf in pat rewe, for pis case may not halle, but $y f$ pere come figures signiticatyf after the eifers. Whan pou 4 hast borowede pre 1 of the next figure signiticatyf, sett pat on ouer pe hede of put tigure of pe quyeh pou wold hane draw pe nep'r ligure ont $\mathrm{y}^{\mathrm{f}}$ pou hadest my $3^{\mathrm{t}}$, \& reken it for ten as pou didest in pe opor ease here-a-fore. Whan pou last pus y-elu loke how $\&$ mony cifers pere were bye-twene palt figure signilicatyf, \& pe tigure

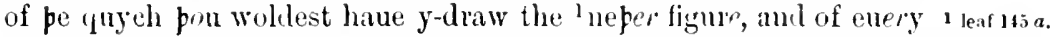
of pe ylke cifers make a figure of 9. lo an Ensimpulle after. 40002 Here is an Tilke 4 ont of 2 . it wel not be. borow 1 out of pe next figure 10004 eximple. 12 significatyf, pe quyeh is 4 , $d$ pen lenes 3 . do awiy pat fignte of 4 \& write pere 3. \& sett prit 1 rppon fe figure of 2 hede, \& fan take 4 ont of ten, \& pan pere lenes 6 . Cast 6 to the figure of 2 , put wol he 8 . do away pat 6 it write pere 8 . Whan pou hast pus $y$-to 1); make of enery 0 betweyn $3 \&$ s a figure of $9, \mathbb{E}$ p:m worch forth in godiles name. \& yf pou hast wel y-do poü schalt hane pis nomber.

I Si subtraccio sit b ne facta p $\cdots$ bare valebis Quas $\mathbf{s} u$ btraxisti primas addendo figuras.

$\lceil 39998\rceil$ sic. 10004

20 There he teches pe Craft how pon selialt know, whan pou hast Huw wrove sultricted, wheper pou hast wel yelo or no. And pe Craft is pis, sumb. ryglit as pou sulitrayd pe neper figures fro pe lier figures, ry $3^{\text {t }}$ so alde pe same neper figures to pe hier figures. And of pou hane 2t well $y$-wroth a-fore pou schalt hane pe hier nombre pe same pou hadlest or pon be-gan to worch. as for pis I bale pou schulde liepe pe neper fignres stylle. lo an "Eusampulle of alle pe $t$ cases s leac Its b. togedie. worche welle pis ease, 40003468 . And yf pou worch welle Here is an 28 whan pou hast alle subtrayd 20004664 pe pect hier nomlire here, pis schalle be pe nombre here foloyng whan pou hast subtrayd 39998804. And pou sehalt know pus. alde pe neper rewe of fe Our author 20004664 same nombre to pe hier rewe as pus, cast 4 to 4 . pat wol liere 3 for 1 .

32 be 8 . do awiy pe 4 is write pere 8 . by pe first case of adlicion. pan east 6 to 0 pat wol be 6 . do away pe 0 , i write pere 6 . pan east 6 to 8 , pat wel be 14 . do away 8 . 1 write pere a figure of 4 , pat is pe eligit, and write a figure of 1 . put schill be token ter. pat 36 is pe articul rjon pe hed of 8 next after, pan reken pat 1 . for 1 . \& east it to 8 . pat schal be 9 . east to pat 9 pe neper figure vnder pat pe quych is 4 , \& pat schalle be 13 . do away fat 9 \& sett pere 3 , \& sett a figure of 1. pat schall be 10 vpon pe next figuris hede pe 2 'hali' marked for erasure in MS. 
quych is 9. by pe secunde ease put fon hadest in adlicion. pan cast 1 to 9 . \& pat wol be 10. do away pe 9 . \& pat 1 . And write pere a eifer. and write pe artieulle pat is 1 . betokenynge 10 . rpon pe hecle of

${ }^{1}$ leaf $146 a$. pe next figure toward pe lyft side, pe quych ${ }^{1}$ is 9 , \& so do forth tyl

He works lis proot tlirough,

Four things nust be known in Duplation.

Here they are.

3 ianf 1466 .

Mlind where you begin.

Remember your rules.

How to work a sum.

pou come to pe last 9 . take pe figure of pat 1 . pe quych pou schalt fynde ouer pe hed of 9 . \& sett it ouer pe next figures lede pat schal be 3. I Also do away pe $9 . \&$ set pere a cifer, $\&$ pen cast pat 1 pat stondes vpon pe hede of 3 to pe same 3 , \& pat schalle make 4 , pen caste to pe ylke 4 the figure in pe neyper rewe, pe quych is 2 , and pat schalle be 6 . And pen schal pou hate an Ensanipulle azeyn, loke \& se, \& but pun haue pis same p»u hase myse-wrozt. 20004664 Sequit $u \cdot$ de duplacione

\section{Qi vis duplare numerum, sic incipe primo $D$ Scribe fig $u$ ar $u m$ serie $m$ quamca $n q u e$ velis: tu.}

I This is the Chapture of duplacion, in pe quyeh eraft pou most haue \& know 4 thinges. If pe first pat pou most know is what is 16 duplacion. pe secunde is low mony rewes of figures pou most haue to pis craft. I pe thryde is how many cases may 2 happe in pis craft. It pe fourte is what is pe profet of pe crift. I As for pe first. duplacion is a doublyng of a nombre. I $A$ s for pe secumde 20 pou most ${ }^{3}$ hane on nombre or on rewe of figures, the quych called numerus dupland us. As for pe thrid pou most know pat 3 diuerse cases may hap in pis craft. As for pe fourte. qwat is pe profet of pis craft, \& pat is to know what a-risyzt of a nombre I-doublyde. 24 If fforper-more, pou most know \& take gode hede in quych sile pou schalle be-gyn in pis craft, or ellis pou mayst spyl alle pi laber pere aboute. certeyn pou schalt begyn in the lyft side in pis Craft. thenke wel ouer pis verse. If ${ }^{4}$ A leua dupla, diuide, multiplica. ${ }^{4} 28$ The sentens of pes verses afore, as pou may see if pou take hede. As pe text of pis verse, pat is to say, $\mathrm{I}$ Si vis duplare. pis is pe sentence. If If pou wel double a nombre pus pou most be-gynn). Write a rewe of figures of what nombre pou welt. versus.

\section{Postea procedas primam duplando figura $n$}

\section{Inde quod excrescit scribas vbi insserit ordo}

Iuxta precepta tibi que dant $u r$ in addicione.

Tा Here he telles how pou schalt worch in pis Craft. he says, 36 fyrst, whan pou hast writen pe nombre pou schalt be-gyn at pe first

$$
2 \text { 'moy' in MS. }
$$

- Subtrahas aut addis a dextris vel mediabis' added on margin of MS. 
tigure in the lyft side, \& lloubulle pat figure, \& fe nombre pat connes pere-of pou schalt write ats pou didilyst in ahlicion', as 9 I schal telle pe in pe cise. versus.

4

1 Nam si sit digitus in primo limite scribas.

3 lear $t 17 a$.

I llere is pe first case of pis eraft, pe quych is pis. yf of dupla- if the answer ciow of a figure arise a digit. what schal pon do. pus pou schal do. do away pe figme pat was doublede, \& sett fere pe liget fat wite it in 8 comes of pe duplacion, as pus. 23. double $2, \&$ pat wel be 4 . do the top away pe figure of $2 \&$ sett pere a figure of $4, \&$ so worch forth tille figure.

pou come to pe ende. versus.

If Articulus si sit, in primo limite cifram,

- Articulu $m$ vero reliquis inscribe figuris ;

- Vel per se scribas, si nulla figura sequatur.

T Here is pe secunde case, pe quyeh is pis $\mathrm{yf}$ pere come an if it is an articulle of pe duplacions of a figme pou schalt do ryzt as pou article,

16 diddyst in aldieion, pat is to wete pat pou schalt do away pe figure pat is doublet $\&$ sett pere a cifer, $\&$ write pe articulle ouer pe put a cipher next figuris helle, $\mathrm{yf}$ pere be any after'warde toward pe lyft side as and 'ciury'

pus. 25. begyn at the lyft side, and doubulle 2. pat wel be 4. do 20 away pat $2 \&$ sett pere 4 . pan doubul 5 . pat wel be 10 . do away 5 , $\&$ sett pere a $0, \&$ sett 1 vpon pe next figuris hede pe quych is 4 . $\&$ pen draw downe 1 to $4 \&$ pat wolle be 5 , \& pen do away pat 4 $\&$ pat 1 , \& sett pere 5 . for pat 1 sehal be rekened in pe drawyuge to24 gedre for 1. wen 2pou hast ydon pou selualt haue pis nombre 50 . yf pere come no figure after pe figure put is allit, of pe quych urthere is addicion) comes an artienlle, pou schalt do away pe figure pat is 'cary' them dowblet \& sett pere a 0 . \& write pe artieul next by in pe same liem down. 28 rewe towarl pe lyft syde as pus, 523 . double 5 pat woll be ten. do away pe figure $5 \&$ set pere a cifer, \& sett pe articul next after in pe same rewe toward pe lyft side, \& pou schalt haue pis nombre 1023. pen go forth \& double pe oper nombers pe quych is ly3t $\mathrm{y}^{\text {- }}$ 32 now 3 to do. versus.

If Compositus si sit, in limite scribe sequente Articulu $m$, primo digitu $m$; quia sic iubet ordo: Et sic de reliquis faciens, si sint tibi plures.

36 T Here he puttes pe Thryel case, pe quych is pis, yf of dupla- If in is a cionv of a figure come a Composit. pou schalt do away pe figrure pat is doublet \& set pere a digit of pe Composit, \& sett pe articulle ouer write durn pe next figures hede, $\&$ after draw hym downe with pe figure ouer and 'carry. 40 whos liede he stondes, $\mathbb{R}$ malie pere-of an nombre as pou hast clone 
afore, \& yf pere come no figure after pat digit pat fou hast y-wite, pan set pe articulle next after hym in pe same rewe as pus, 67 : clouble 1 leaf 148 . 6 pat wel be 12 , do away $6 \&$ write fere pe digit 1 of 12 , pe yuych Here is an is 2, and set pe articulle next after toward pe lyft side in pe same
example.

How to dutible the nark for one-half. rewe, for pere comes no figure after. pan dowble pat oper figure, pe quych is 7 , pat wel be 1 t. the quych is a Composit. pen do away 7 pat pou doublet \& sett pe pe diget of hym, the quych is $t$, sett pe articulle oner pe next figures hed, pe quych is 2 , \& pen draw to hym pat on, \& make on nombre pe quych schalle be 3 . Ant pen yf pou hane wel $y$-ilo fou schalle haue pis nombre of pe duplacion, 13t. versus.

If Si super extremann nota sit monade $m$ dat eidem Quod tifi contingat si primo dimidiabis.

If Here he says, yf oum pe fyrst figure in pe ryzt side be such a merke as is here made, ", pou schalle fyrst doubulle pe figure, the quych stondes vnder pat merke, \& pen pou schalt doubul pat merke pe quych stondes for haluendel on. for too haluedels make; on, \& 16 so pat wol be on. east pat on to pat duplacion of pe figure oues. whos hed stode pat merke, $\mathbb{S}$ write it in pe same place pere pit pe figure pe quych was doublet stode, as pus $23^{\text {w. }}$. clouble 3 , pat wol be 6 ; doubul pat halue on, \& pat wol be on. cast on to 6 , fat wel be 20 7. do away $6 \&$ pat $1, \&$ sett pere 7 . pau hase pou do. as for pat ${ }^{2}$ Ieaf 148 b. figure, pan go ${ }^{2}$ to pe oper figure \& worch forth. \& pou schall neu $\%$. This can ouly have such a merk but over pe hed of pe furst figure in pe ryoght
stand over the first figure.

side. And zet it schal not happe but yf it were $y$-halued a-fure, pus 24 pou schalt vnderstonde pe verse. II Si super extreman \&c. Et nota, talis figun " significans medietatem, unitatis veniat, i.e. contingat uel fiat super extremam, i.e. super primam figuram in extremo sic versus dextram ars dat : i.e. reddit monarlem. i.e. vnitatem eidem. 28 i.e. eidem note \& declina tur hec monos, dis, di, dem, \&c. If Quod ergo totum hoc dabis monalem note continget. i.e. eveniet tibi si dimidiasti, i.e. accipisti uel subtulisti medietatem alicuins unius, in cuius prineipio sint figura numer $u m$ denotans imparem primo i.e. principiis. 32

Tा Sequitur de mediacione.

Tncipe sic, si vis alique $m$ numera $m$ mediare:

1 Scribe figurar $\iota m$ seriem solam, velut ante.

The four things to be known in
mediation:

the first
II In pis Chapter is tajt pe Craft of mediacioun, in pe quych 36 craft pou most know 4 thynges. ffurst what is mediaciond. the secunde how mony rewes of figures pou most have in pr. wyrchynge of pis craft. pe thryde how mony diuerse cases may happ in pis craft. $^{3}$ I As for pe furst, pou schalt vndurstonde pat mediacion is a 40 3 After 'craft' insert ' the .4. what is pe profet of pis craft.' 
takyng out of halfe a nomber out of a holle nomber, 'as yf pon ' leafira. wolde take 3 out of 6 . If As fur pe secunde, pou schalt know prit the second; pou most hane one rewe of figures, $\&$ no moo, as pou hayst in pe 4 craft of duplacion. If As for the thryd, pou most vulferstonde pat the thiri;

5 cases may happe in pis craft. If As for pe fourte, pou schalle the fouth. know pat the profet of pis eraft is when pou hast take away pe lialuentel of a nombre to telle qwat pere schalle lene. If Incipe $8 \mathrm{sic}, \mathrm{kc}$. The sentence of pis verse is pis. yf pout wold melye, pat is to say, take halfe out of pe holle, or halfe out of halfe, pou most begynne pus. Write one rewe of figures of what nombre pou wolle, Begin ilus. as por dydulyst be-fore in pe Craft of duplacion). versus.

I Postea procedas medians, si prima figura Si par aut impar videas.

I IIere he says, when pon hast write a rewe of figures, pou schalt take hede wheper pe first figure be enew) or odde in nombre, See if the 16 \& vnderstontle put he spelies of pe first fignre in pe ry3t side. And even or odt. in the ryorth side pou schalle begynne in pis Craft.

\section{If Quia si fuerit par,}

\section{Dimidiabis eam, scribe $n$ s quicq $u$ id remanebit:}

20 Ti Here is the first case of pis craft, pe quych is pis, $y \mathrm{f}$ pe first it it is even, figure be eucn. pou schal take away fro pe figure enten halfe, \& do thilre ith an away pat figure and set pere pat lenes ouer, as pus, 4 . take ${ }^{2}$ halfe its place. ont of $4, \&$ pan pere leues 2 . lo away $4 \&$ sett pere 2 . pis is lyght

2 le.if $149 b$ $21 \mathrm{y}$-now3t. versus.

\section{Tा Impar si fuerit vnum demas mediare}

\section{Quod non presumas, seel quod superest mediabis}

Inde super tractum fac demptum quod notat vuum.

28 Here is pe secunde case of pis craft, the quych is pis. yf pe 1 it is ond,

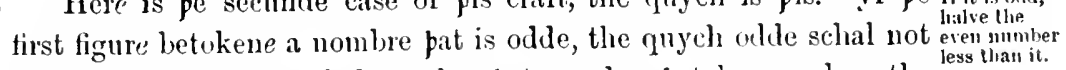
be mediete, pen pou schalt medye pat nomhre pat lenes, when the odele of pe same nombre is take away, \& write pat put leues as pou 32 diddest in pe first case of pis craft. Whaw pou hayst write pat. for prit pat leues, write such a merke as is here w vpon his hede, pe quych Then write merke schal betoken) halfe of pe odle pat was take away. lo anl lie sign for Ensampull. 245. the first figur here is betokenynge odcle nombre, 36 pe quych is 5 , for 5 is odde; pere-fore tho awny pat pat is odde, pe llere is an quych is 1 . pen lenes 4 . pen medye $4 \&$ pen leues 2 . do away 4 . \& sette pere 2 , \& make such a merke " upon his hede, pat is to say oner his lieile of 2 as pus. 242." And pen worch forth in pe oper 40 figures tyll pou come to pe ende. by pe furst case as pou schall, NOMERYNGE. 
${ }^{1}$ leaf $150 a$. vullerstonde pat pou selialt 'neuer make such a merk but oner pe

Put the mark only over the first figure.

If the first figure is one put a ciplier.

Wliat to do if any other:
figure is ond.

2 leaf $150 \mathrm{~b}$. Write a

figure of five over the next lower number's heal.

Example. first figure hed in pe rizt side. Wheper pe other figures pat comyn after hym be euen or odde. versus.

Tा Si monos, dele; sit tilii cifra post nota supra.

Tा Here is pe thryde case, pe quych yf the first figure be a figure of 1. pou schalt do away pat $1 \&$ set pere a cifer, \& a merke oner pe cifer as pus, 241. (lo away 1 , \& sett pere a cifer with a merke ouer. his hele, \& peu hast pou ydo for pat 0 . as pus $0^{\text {w }}$ pen worch forth in pe oper fignrys till pom come to pe ende, for it is lyght as dyche water. vude versus.

I Postea procedas hac condicione secunda :

Impar si fuerit hinc vnum deme priori,

Inscribens quinque, nam denos significabit

Monos predictam.

T Here he puttes pe fourte case, pe quyeh is fis. yf it happen the secunde figure betoken odle nombre, pou schal do away on of 16 pat odde nombre, pe quyeh is significatiue by prit figure.1. pe quych 1 schall be rekenle fur 10 . Whan pou hast take away pat 1 ont of fe nombre pat is signifiede by pat figure, pou schalt merlie pat pat leues oner, \& do away pat figure pat is medied, \& sette in his styde 20 halfe of fat nombre. Th Than pou hase so clone, pou schalt write 2 a figure of 5 oner pe next figures hede by-fore toward pe ry3t side, for pat 1 , pe quych male odil nombre, schall stonde for ten, \& 5 is lialfe of 10; so pou most write 5 for his haluendelle. 10 an En-24 sampulle, 4678. begyn in pe ry t side as pon most neles. medie 8 . pen pou selialt leue 4. do away pat $8 \&$ selte pere 4 . pen out of 7 . take away 1 . pe quyel makes odde, \& sett 5 . vpon pe next figures hede afore toward pe ry3t side, pe quych is now 4. but afore it was 28 8 . for pat 1 selial be rekenet for 10 , of fe quych 10,5 is halfe, as pou knowest wel. Whan pou hast pus ydo, medye fat pe quych leues after pe takyinge away of pat pat is odde, pe quych leuynge schalle be 3 ; do away $6 \&$ sette pere $3, \&$ pon schalt liane such a 32 nombre 4634 . after go forth to pe next figure, \& medy pat, $\&$ worch forth, for it is ly 3 t ynorzt to pe certayn.

\section{T Si vejo secunda dat vnum.}

Illa deleta, scribatur cifra; priori

I Tradendo quinque pro denario mediato;

Nec cifra scribatur, nisi deinde figura sequat $u^{\prime}$ :

Postea procedas reliqurıs mediando figuras

Vt supra docui, si sint tibi mille figure. 
T Here he puttes pe 5 ease, pe quych is ${ }^{1}$ pis: yf pe secunde 1 leaf $151 \mathrm{a}$. figure he of 1 , as pis is here 12 , pou schalt to away pat $1 \&$ sett $\begin{aligned} & \text { If the gecond } \\ & \text { figure is one, } \\ & \text { put }\end{aligned}$ pere a cifer. \& sett 5 oner pe next figure hede afor toward pe rizt $\begin{gathered}\text { put a cipher. } \\ \text { andite fivo }\end{gathered}$ 4 sile, as pou diddyst afore; \& pat 5 schal be haldel of pat 1, pe $\begin{gathered}\text { orer the next } \\ \text { figure. }\end{gathered}$ (quych 1 is rekent for 10. lo an Ensampulle, 214. medye 4. fat schalle be 2. do away 4 \& sett pere 2 . pen go forth to pe next figure. pe quych is hot 1 . do away pat 1 . \& sett pere a cifer. \& set 85 vpon pe figures hed afore, pe quych is nowe $2, \&$ pen pou schalt haue pis nombre 202, pen worch forth to pe nex figure. And also it is no mastery yf pre come no figure after pat on is medyet, pou schalt write no 0 . ne now 3 t ellis, but set 5 ouer pe next figme afore 12 towarl pe ry 3 t, as pus 14 . medie 4 then leues 2 , do away 4 \& sett Huw to halie pere 2 . pen medie 1 . pe quich is rekende for ten, pe haluendel pereof wel be 5 . sett pat 5 vpon pe hele of pat figure, pe quych is now $2, \&$ do away pat $1, \&$ pou schalt hane pis nombre yf pou 16 worch wel, 2 . vnde versus.

\section{T Si mediacio sit bene farta probare valebis \\ If Duplando num $r$ a $m$ quem primo dimediasti}

T Here he telles pe how pou schalt know wheper pou hase wel How to prove 20 ydo or no. doubul ${ }^{2}$ pe nombre pe cuych pou hase mediet, and $y$ f your. fou haue wel y-medyt after pe dupleacion, pou schalt haue pe same nombre pat pou hadalyst in pe talbille or pon began to medye, as pus. T The furst ensampulle was pis. t. pe quych I-medict was first 24 laft 2 , pe whyel 2 was wite in pe place put 4 was write afore. Now doubulle pat 2, \& pou schal hane 4, as pou hadyst afore. pe secunde Ensampulle was pis, 245 . When pou haddyst mediet alle the second. pis nombre, yf pou hane wel ydo pou schalt hane of pat mediacion) 28 pis nombre, $122^{\text {w. }}$. Now doululle pis nombre, \& bergn in pe lyft side; cloubulle 1 , pat schal be 2. clo away pat 1 \& sett pere 2 . pen doubulle pat oper 2 \& sett pere 4, pen cloubulle pat oper 2 , \& pat wel be 4. pen cloubul pat merke pat stondes for halue on. \& pat schalle 32 be 1 . Cast pat on to 4 , \& it sehalle be 5 . do away pat $2 \&$ pat merke, \& sette pere $5, \&$ pen pou schal haue pis nombre $245, \&$ pis wos pe same nombur put pon liaddyst or pou began to medye, as pon mayst se yf pou take hede. The nombre pe quych pou haddist 36 for an Ensampul in pe 3 case of mediacionl to be mediet was pis rie third 241. whan pou hadlist medied alle pis nombur truly ${ }^{3}$ by enery ${ }^{3}$ leaf $152 a$. fignre, pou schall hane be pat mediacion pis nombur 120\%. Now dowbul pis nombur, \& begyn in pe lyft side, as I tolde pe in be 40 Craft of duplacious. pus doubulle pe figure of 1 , pat wel be 2 . do 
away pat $1 \&$ sett pere 2 , pen doubul pe next figure afore, the quych is 2 , \& pat wel be 4 ; do away $2 \&$ set pere 4 . pen doubul pe cifer, $\&$ pat wel be no3t, for a 0 is nozt. And twyes nozt is but nozt. perefore doubul the merke aboue pe cifers hede, be yuych betokeues pe haluentel of $1, \&$ pat selial be 1 . do away pe cifer $\&$ be merke, \& sett pere $1, \&$ pen pou schalt haue pis nombur 241. And pis same nombur pou hadlyst afore or pou began to medy, \&

The fourth exanple.

The fifin example. yf pou take golle hele. If The next ensampul pat laal in pe 4 case 8 of mediacion) was pis 4678 . W'han pou hast truly ymedit alle pis nombur fro pe begymnynge to pe endynge, pou schalt haue of pe mediacion) pis nombur 2334. Now doubul this nombur \& begyn in pe lyft side, $\&$ doubulle 2 pat schal be 4 . do away 2 and sette pere 12 4 ; pen doubule 3 , pat wol be 6 ; do away $3 \&$ sett pere 6 , pen 3 leaf $152 b$. donbul pat oper 3 , \& pat wel be 6 ; lo away $3 \&$ set pere ${ }^{1} 6$, pen doubul pe 4 , pat welle be 8 ; pen doubul 5 . be quyeh stondes ouer pe hed of 4 , \& pat wol be 10 ; cast 10 to 8 , \& pat schal be 18 ; do 16 away $4 \&$ pat 5 , \& sett pere 8 , \& sett that 1 , pe quych is an articul of pe Composit pe quych is 18 , oner pe next figures hed towarl pe lyft side, pe quych is 6 . drav pat 1 to 6 , pe quych 1 in pe dravyng schal be rekente bot for $1, \&$ pat $1 \&$ pat 6 togeclur wel be 7 . 10 20 away pat $6 \&$ fat 1 . the quych stondes our his hede, $\&$ sett ther 7 , $\&$ pen pou schalt haue pis nombur $467 \mathrm{~s}$. And pis same nombur pou hidyst or pou began to medye, as pou mayst see in pe secunde Ensampul pat pou had in pe 4 case of mediacion, pat was pis: when 24 pou had mediet truly alle the nombur, a principio usque ad finem. pou schalt liaue of pat mediacion pis nombur 102. Now doubul 1. pat wel be 2 . do away $1 \&$ sett pere 2. pen doubul 0 . prit will be nozt. perefore take pe 5 , pe quych stondes ouer pe next figures 28 hed, \& doubul it, \& pat wol be 10. lo away pe 0 pat stonles betwene pe two figuris, \& sette pere in his stid 1 , for pat 1 now schal stonde in pe secunde place, where he schal betoken 10 ; pen

leat 1:3a doubul 2 , pat wol be 4 . do away $2 \&$ sett pere $4 . \&{ }^{2}$ pon schal haue 32 pus nombur 214. pis is pe same numbur pat pou halyst or pon began to medye, as pou may see. And so do ever more, yf bou wil knowe wheper pou hase wel ymedyt or no. T. doubulle pe numbur pat comes after pe mediacioun, \& pou schal hane pe same nombur 36 pat pon luadyst or pou began to medye, yf pou haue welle yclo. or els doute pe nozt, but yf pou haue pe same, pou hase faylide in pi Craft.

$$
\text { Sequitur de multiplicatione. }
$$




\section{Qi tu per numerum numer $\mathrm{u} m$ vis multiplicare \\ S Scribe duas quascunque velis series numerorum Ordo s"vetu vt vltima multiplicandi \\ A leua relique sint scripte multiplicantes.}

T Here be-gymmes pe Chaptre of multiplieation), in pe quych Fonr things pou most know 4 thynges. If Ffirst, qwat is multiplicacion. The of kn known: s secunte, how mony cases may hap in multiplicacion. The thry le, how mony rewes of figures pere most be. T The 4. what is fe profet of pis craft. If $A$ s for pe first, pou schal vulerstonde pat the first: inutiplicacionl is a bryngyge to-geder of 2 thynges in on nombur, 12 pe quych on nomlur contynes so mony tymes on, howe lmony 1 leaf $153 b$. tymes fere ben rnytees in pe nowmbre of pat 2 , as tiryes 4 is 8 . now here ben pe 2 nombers, of pe quyeh too nowmlres on is betokened be an aduerbe, pe quych is pe worde twyes, \& pis worde 16 thryes, \& pis worle foure sythes, 2 \& so furth of such other lyke wordes. If And tweyn nombres schal be tokenyile be a nowne, as pis worde foure showys pes tweyn nombres $y$-broth in-to on hole nombur, pat is 8 , for twyes 4 is 8 , as pou wost wel. If And pes 20 nombre 8 conteynes as of tymes 4 as pere ben rnites in pat other nombre, pe quyeh is 2 , for in 2 ben 2 vnites, $\&$ so oft tymes 4 ben in 8 , as pou wottys wel. If for pe secunde, pou most know pat pou the seconi: most hane too rewes of figures. If As for pe thryde, pou most know the thist:

24 pat 8 maner of diumse case may happe in pis craft. The profet of pis Craft is to telle when a nombre is multiplyed be a noper; qwat the formb. commys pere of. If fforthemore, as to pe sentence of oure verse, yf pon wel multiply a nombur be a-noper nomber, bou sehalt write $2 S^{3}$ a rewe of figures of what nomburs so euer pon welt, \& pat sehal be "leat 154 . called Numerus multiplicandus, Anglice, pe nombur the quych to The multiplibe multipliel. pen pon schalt write a-nother rewe of figures, by pe quych pon schalt multiplie the nombre pat is to be multipliet, of pe 32 "fuych nombur pe furst figmre schal be write vuler pe last figure of pe nombur, pe quych is to be multiplied. And so write forthe towarl pe lyft side, as here you may se, And pis one liow to set nombur schalle be called numerns multi- 1234 plicans. Any- domn.

36 lice, pe nombur multipliynge, for he schalle multiply pe hyer nounbur, as pus one tyme 6 . And so forth, as I schal tello the afterwarle. And pou schal hegyn in pe lyft side. If ffor-pere-more pou schalt

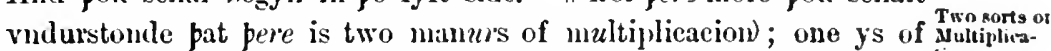
40 pe wyrehynge of pe boke only in pe mynde of a mon. fyrst he tion:

\footnotetext{
$\because$ After 'sfthes' insert ' $\&$ pis wordes fyue sithe $\&$ sex sythes.'
} 
mal on paper. teches of pe fyrst maner of duplacion, pe quych is be wyrchynge of tabuls. Aftriwarde he wol teche on pe secunde maner. vinde versus.

1 leaf $15 \pm b$.

In digitum cures digitum si ducere maior

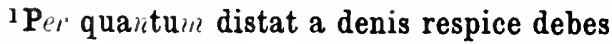

T Namque suo decuplo totiens delere minorem

Sitque tibi numerus veniens exinde patebit.

How to multiply 1 wo digils.

Tा Here he teches a rewle, how pou schalt fymle pe nombre pat 8 comes by pe multiplicacioni of a digit be anoper. loke how mony [rny] tes ben. bytwene pe more digit and 10. And reken ten for on vnite. And so oft do away pe lasse nounbre out of his owne

Sublract the greater from ten; decuple, pat is to say, fro pat nounbre pat is ten tymes so mych is 12 pe nounbre prit comes of pe multiplicaciond. As yf pou wol multiply 2 he 4 . loke how mony vitees ben by-twene pe quyeh is pe more nombre, \& be-twene ten. Certen pere wel he vj vnitees by-twene 4

take the less so many times from ten times itself. $\&$ ten. yf pou reken pere with pe ten pe vnite, as pou may se. so 16 mony tymes take 2. out of his decuple, pe quych is 20 . for 20 is pe decuple of 2,10 is pe leculle of 1,30 is pe decuple of 3,40 is pe decuple of 4 , And pe oper digretes til pou come to ten; $\&$ whan pou Example. Last $y$-take so mony tymes 2 out of twenty, pe culych is sex tymes, 20 pri schal leue 8 as pou wost wel, for 6 times 2 is twelue. take [1]2 out of twenty, \& pere schal lene 8 . bot yf bothe pe digrettes 2 leaf 155 a. "Juen y-lyech mych as here. 222 or too tymes twenty, pen it is no fors quych of hem tweyn pou take out of here decuple. als mony 24

Belter use this lable, tymes as pat is fro 10 . but nener-pe-lesse, yf pou laaue hast to though. worch, pou schalt have here a tabul of figures, where-hy pou schalt se a-nomn ryght what is pe nounlore pat comes of pe multiplicaciou of 2 digittes. pus pon sehalt worch in pis fignre.

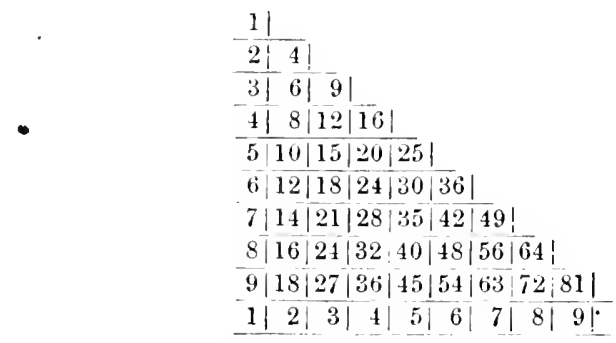

How to use it. $y$ f pe figure, pe quych schalle be multiplied, be enene as mych as pe 29 diget be, be quyeh pat oper figure schal be multiplied, as two tymes twayn, or thre tymes 3 . or sych other. loke qwere pat figure sittes in 
pe lyft side of pe triangle, \& loke ywere pe diget sittes in pe neper The way ro most rewe of pe triangle. \& go fro hym vpwirde in pe same rewe, tise the blut. be yuych rewe gose viwarde til pou come agaynes pe cper digette pat 4 sittes in pe lyft side of pe triangle. And patt nounbre, pe quych pou fyn' ${ }^{1}$ des pere is pe nounbre pat eomes of the multiplicacion of pe '2 ' lear 1530 . digittes, as yf pou wold wete quat is 2 tymes 2 . loke quere sittes 2 in pe lyft sile in pe first rewe, he sittes next 1 in pe lyft side al 8 on hye, as pou maly se; pe[n] loke ywere sittes 2 in pe lowyst rewe of pe triangle, \& go fro liym vpwate in pe same rewe tylle pou come a-zenenes 2 in pe liyer place, \& per pon schalt fynd $y$ write 4 , $\&$ pat is pe nombre pat comes of pe multiplicacion of two ty'mes 12 tweyn is 4 , as pow wotest welle. yf pe diget. the quyeh is multiplied, be more ban pe oper; pou sehilt loke ywere pe mor diget sittes in pe lowest rewe of pe triangle, \& go vpwarle in pe same rewe tyl ${ }^{2}$ pou come a-nendes pe lasse diget in the lyft side. Aml

16 pere pou schalt fynde pe nombre pat eomes of pe multiplicacion; but pou schalt vnderstonde pat pis rewle, pe quyeh is in pis verse. If In digitum cures, \&e., noper pis triangle schalle not serue, bot to fynde pe nounbres pat comes of the multiplieacionl pat comes of 2 20 artieuls or composites, pe nedes no craft but yf pou wolt multiply in pi mynde. And ${ }^{3}$ pere-to pou sehalt haue a craft afterwarle, for 3 leaf 156 a. pou sehall wyreh with digettes in pe tables, as pou sehalt know afterwarde. versus.

II Postea prucedas postrema $m$ multiplicando [Recte multiplicans per cunctas inferiores] Condicionem tamen tali quol multiplicantes Scribas in capite quicquid processerit inde Sed postquem fait hec multiplicate figure Anteriorent $u$. serei multiplicantis Et sic multiplica velut isti multiplicasti

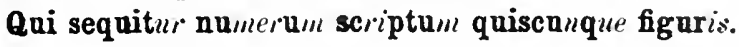

If Here he teches how pou schalt wyrch in pis crift. pou sehalt How con multiplye pe last figure of pe nombre, and quen peu hast so ydo pou mustler by schalt draw alle pe figures of pe neper nombre more tawarl be ryst side, so qwen pou hast multiplyed pe last figure of pe heyer nounlyre

36 by alle pe neper figures. And sette pe nounbir pat comes per-of oner Mnultiply the pe last figure of pe nefer nounbre, di pen pou sehalt sette al pe oper lint he thimer

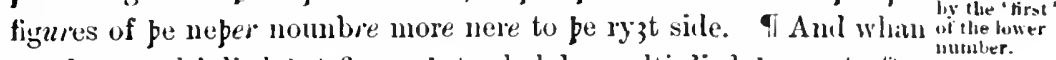
pou hast multiplied pat figure pat sehal be multiplied pe next after.

$$
2 \text { ' } t \text { 'l' marked for erasure before ' } t y l \text { ' in MS. }
$$


hym by al pe neper figures. And woreh as pon dyddyst afore til 1 lear 150 b. ' pou come to pe encle. And pou schalt vuderstonde pat enery Set the an- figure of pe hier nombre schal be multiplied be alle pe figures of the swer orer the nefer nounbre, yf pe lier noumbre be any figure pen one. lo an
fower: Ensampul here fulowynge. $\overline{2} \overline{165}$; pou sehalt begyne to multiplye in pe lyft side. Mrultiply 232 2 be 2 , and twyes 2 is 4 . set 4 then multi- ouer pe hed of pat 2 , pen multiplie pe same hier 2 by 3 of pe nether ofy the escorrer, nounbre, as thryes 2 pat schal be 6 . set 6 our pe hed of 3 , pan und so on. multiplie pe same hier 2 by pat 2 pe quyeh stondes vnder hym, pat wol be 4; do away pe lice $2 \&$ sette pere 4 . T Now pou most Then antery antery pe nether nounbre, pat is to say, pun most sett pe neper
the lawer number: nounbre more towarle pe ry 3 t side, as pus. Take pe neper a toward 12 pe ryst side, $\&$ sette it enew vinler be 4 of pe hyer nounbre, $\&$ antery alle pe figures pat comes after pat 2 , as pus; sette 2 vinler pe 4. pen sett pe figure of 3 pere pat pe figure of 2 stode, pe quych is now vndur pat 4 in pe hier nounbre; pen sett pe oper figure of 2,16 pe quych is pe last figure toward pe ly ft side of pe neper nomber pere as thus. pe figure of 3 stole. pen pou schalt haue such a nombre $\overline{464465}$ ${ }^{2}$ leaf $15 \pi$ a. $=9$ Now multiply 4 , pe ruych comes next after 6 , by pe last 232 2 of pe neper nombur toward pe lyft side. as 2 tymes 4 , pat wel be 20 8. sette pat 8 oner pe figure the quych stondes ouer pe helle of pat 2 , pe quych is pe last fignre of pe nepor nombre; pan multiplie pat same 4 li, 3 , pat comes in pe neper rewe, pat wol he 12. sette pe digit of pe composyt ouer pe figure pe quyeh stomles ouer pe heel of 24 pat $3, \&$ sette pe articule of pis composit oner al pe figures pat Now nuti- stondes oner pe neper 2 hede. pen multiplie pe same 4 by pe 2 in ply lyy the last but one of the higlier

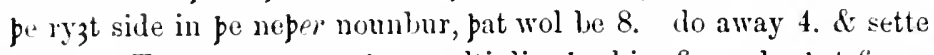
pere 8 . Eur more qwen pou multiplies pe lier figure by pat figure 28 pe quych stonles vinder hym, pou schalt do away pat hier figure, \& sett per pat nounbre pe ynych comes of multiplicacion of ylke digittes. Whan pou hast done as I hane bycle pe, pou sehalt hane ae thus. suych an order of fignre as is here, pi neper fignres. And sett pe fyrst figures ${ }^{3}$ vndre pe figure of 6 .

$\left[\begin{array}{c}\frac{1}{4} 2 \\ 4648[65] \\ 232\end{array}\right]$
232 pen take and antery 32 figure of pe neper If And draw al pe

4 leaf $15 \pi$. oper figures of pe same rewe to bym-warde, ${ }^{4}$ as pou diddyst afore. pen multiplye 6 be 2 , \& sett pat pe quyeh comes oner pere-of 36 oner al pe oper figures hedes pat stondes ouer pat 2. pen multiply 6 he 3 , \& sett alle pat comes pere-of vpon alle pe figures heiles pat stamles oner pat 3 ; fan multiplye 6 be 2 , pe quyeh ${ }^{3}$ Hire 'of fe same rew' is marked for erasure in MS. 
stondes vnder pat 6 , pen do away $6 \&$ write pere fe digitt of pe composit pat sehal eome perpof, $\mathbb{E}$ sette pe articull our all pe figures pat stomies oue' pe hele of fat 3 as here, pen 11

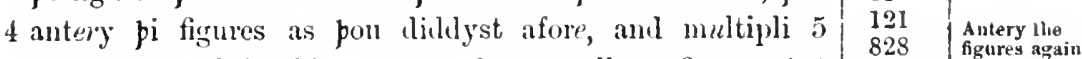

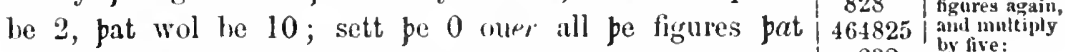
stonden ouer pat 2, \& sett prit 1. oner the next figures 232 heles, alle on hye towarle pe lyft sirle. pen multiplye 5 he 3 . pat 8 wol be 15 , write 5 oner pe figures herles pat stonden oner pat 3 , \& sett pat 1 oner pe next figures heiles towarl pe lyft sile. pen multiplye 5 he 2 , pat wol be 10 . do away pat 5 is sett pere a 0, “ sett pat 1 ouer pe figures hecles fat stonden our 3 . And prn

12 pou schalt laue such a numbre as here stomles aftur. T Now haw alle pese figures downe togreler as pus, 6.8.1. \& 1 draw to-gedur; pat wolle be 16 , do away alle pese figures save 6. lat liym stonle, for pow pon take liym 16 away pou most wite per fe same azene. perefore late 11 1101 1215 82820 4648

232 lym stomle, i sett 1 ouer pe figure hede of 4 toward pe lyft side ; Then add an pen draw on to 4 , pat wolle be 5 . lo away pat 4 \& pat 1 , \& sette the ngeveres pere 5. pen dlaw $4221 \& 1$ togedur, pat wol be 10 . do away alle 20 pat, \& write fere pat 4 \& pat 0 , \& sett pat 1 oner pe next figures hele towarl pe lyft sile, pe quych is 6 . peri draw pat 6 . 8 pat 1 togehur, \& pat wolle be $\tau$; do away $6 \&$ sett pere 7 , pen draw 8810 $\& 1, \&$ pat wel be 18 ; do away alle pe figures pat stondes oner pe 24 hete of pat $8, \&$ lette 8 stomle stil, \& write pat 1 oue pe next figuris hede, pe quyeh is a 0 . pen do away pat 0 , \& sett pere 1 , pe quych stondes oner pe 0 . hede. pen draw $2,5, \& 1$ togerlu; pat wolle be 8 . pen do away alle pat, \& write pere $\&$. I And pen pon and you will 28 schalt haue pis nounbre, 571880 .

2T Serl cam multiplicabis, primo sic est operandam, Si dabit articulum tibi multiplicacio solum; Proposita cifra su $\cdots$ mam tionsferre memento.

32 I Here he puttes pe fyrst case of pis eraft, pe quych is fis: What to do yf pere come an articulle of pe multiplicacion ysette before the inthe first articulle in pe lyft sicle as pus 51 . multiplye 5 by 2 , pat wol be in an article. 10 ; sette oner pe hede of pat 2.23 a $0, \&$ sett pat on, pat is pe 36 articul, in pe lyft sile, pat is next hym, pen pon schalt haue pis nounbre 1051?. If And pen worch forth as pou diddist afore. And pou 23 schalt vmlesstomle pat pon schalt write no 0 . but whan pat place where pou sehal write pat 0 has no figure afore 40 hym noper after. versus. 


\section{If Si autem digitus excreuerit articul $\iota$ 'que.} Articulus sup rapsito digito salit vltra.

What to do if the result is a composite numbel.

2 leaf 159 a.

What if it be a digit.

The fourtli cave of the craft.

- leaf 1596 . The fifth rase of the craft.

I Here is pe secunde case, pe quyeh is pis: yf hit happe pat pere come a composyt, pou schalt write pe digitte oute pe hede of pe neper figure by pe quych pou multipliest pe hier figure; and sett pe articulle next hym towarl pe lyft side, as pou didlyst afore, as pus 73. Multiply 8 by 8 , pat wol be 64 . Write pe 4 ouer 8 , pat is 83 to say, out' pe hecle of pe neper 8 ; $\&$ set 6 , pe quyeh ${ }^{2}$ is an articul, next after. And pen pon sehalt hane such a nounbre as is here, $\overline{6483^{3}}$, And pen worch forth. 83

Ti Si digitus tamen ponas ipsum super ipsam.

T Here is pe thrycle ease, pe quych is pis: yf hit happe pat of pi multiplicacionn eome a digit, pou schalt write pe digit oner pe hede of pe neper figrure, by the cuyeh pon multipliest pe hiere figure, fur pis nedes no Ensampul.

- Subdita m /ltiplica non hanc que [incidit] illi Delet ea/l penit $u s$ scribens quod prouenit inde.

- Here is pe 4 case, pe quyeh is: yf hit be happe pat pe neper figure schal multiplye pat figure, pe ruych stoules ouer pat figures 20 hede, pou schal do away pe hicr figure \& sett pere pat pat eomys of pat multiplicacion. As yf pere come of pat multiplicacion an artieuls pou schalt write pere pe hier figure stode a 0 . If And write pe artienls in pe lyft side, yf pat hit be a digit write pere a 24 digit. yf pat hit he a composit, write pe digit of pe composit. And pe articul in pe lyft side. al pis is ly $3^{t} y$-now 3 t, pere-fore per nedes no Ensampul.

9i S $e_{l} l$ si multiplicat alia $u$ ponas super ipsam

Adiunges numer $\mathbf{u}_{\text {"l }}$ quem prebet ductus ear $u m$.

- Here is pe 5 case, pe 'quych is pis: yf ${ }^{4}$ pe neper figure schul multiplie pe lier, and pat hier figure is not recte ouer his hede. And pat neper figure hase oper figures, or on figure oner lis hele by 32 multiplicacion, pat hase be afore, pou schalt write pat nounbre, pe quych comes of pat, oner alle pe ylke figures hedes, as pus here: 236 Multiply 2 by 2 , pat wol be 4 ; set 4 ouer pe hede of pat 2 . 234 pen ${ }^{5}$ multiplies pe hier 2 by pe neper 3 , pat wol be 6 . set 36 oner his heele 6 , multiplie pe hier 2 by pe neper 4 , pat wol be 8 . do away pe hier 2 , pe quych stondes ouer pe hede of pe figure of 4 ,

1 ' $\mathrm{s}$ d' deleter in MS. 3683 in MS. 
and set pere 8 . And pou schalt hane pis nounbre here $\overline{46836} ?$. And antery pi figures, pat is to say, set pi neper 4 vnder pe 234 hier 3, and set pi 2 other figures nere hym, so pat pe neper 2 stonde vud $m^{\prime}$ 4 pe hier 6 , pe quych 6 stomles in pe lyft side. And pat 3 pat stondes mdur 8 , as pus aftur ze may se, 46836 Now worch forthermore, And multiplye pat hier 3 by 2, 234 pat wol be 6 , set pat 6 pe quyelı stondes oner be hede of pat 2, And pen woreh as I tazt pe 8 afore.

1 T Si supiaposita cifra debet multiplicare

1 leaf $160 a$.

Prorsus ea $/ 1$ deles \& ibi scribi cifra debet.

I Here is pe 6 case, pe quych is pis : yf hit happe pat pe figure Thesixthease

12 by pe quych pon schal multiplye pe hier fignre, pe quyeh stondes of the craft. ryght oner hym by a 0 , pou schalt do away pat figure, pe quych oner pat eifre hede. I And write pere pat nounbre pat comes of pe multiplicacion as pus, 23. do away 2 and sett pere a 0 . rnde

16 rersis.

\section{Si cifra multiplicat aliam positam super ip:am}

Sitque locus supra vacu $u$ super hanc cifram fiet.

1 Here is pe 7 case, pe quych is pis: yf a 0 schal maltiply a The seventh 20 figure, pe quych stondes not recte oner hym, And oue, pat 0 crint. stonde no thyng, pou schalt write oner pat 0 anoper 0 as pus: $\overline{\mathbf{2}}$ multiplye 2 be a 0 , it wol be nothynge. write pere a 0 oner pe 03 hede of pe neper. 0 , And pen worch forth til pou come to pe ende.

I Si supi $a^{2}$ fuerit cifra semper est pietereunda.

I Here is pe 8 case, pe quyeh is pis : yf pere be a 0 or mony the eighth cifers in pe hier rewe, pou schalt not multiplie hem, bot let hem ereseft. stonde. And antery pe figures benepe to pe next figure sygnificatyf 28 as pus : 00032 . Ouer-lepe alle pese cifers \& sett pat ${ }^{3}$ neper 2 pat 3 leaf $160 \mathrm{~b}$. stondes 22 toward pe ryght side, and sett hym vndur pe 3 , aud sett pe oper nether 2 nere hym, so fat he stonde rndur pe thrydle 0 , pe quyeh stomles next 3 . And pan worch. vade versus.

I Si dabites, an sit bene multiplicacio facta, Dinide totalem namer $\mathbf{u}_{\prime \prime \prime}$ per multiplicante $\ldots$.

I Here he teches how pou sehalt know wheper pou hase wel I- How to prove do or no. And he says pat pou schalt deuide alle pe nounbre pat catiou. 36 comes of pe multiplicacion by pe neper figures. And pen pou schalt haue pe same nounbur pat pou hadyst in pe begymnyge. but zet pou hast not pe craft of dyuision, but pou schalt hane hit afterwarde.

: 'Supra' inserted in MS. in place of 'cifra' marked for erasnre. 


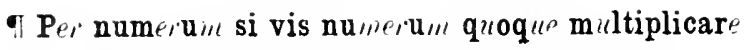

9i Tantum per' normas subtiles absque figuris Has normas pot $e r$ is per versus scire sequentes.

Mental multiplication.

If Here he teches pe to multiplie be powzt fignres in pi mynule. 4 And pe sentence of pis verse is pis: yf pou wel multiplie on nounbre by anoper in pi mynde, pou schal hane pereto rewles in pe verses pat schal come after.

I Si tu pe ${ }^{\prime}$ digitu $/$ digitu $/$ vis multiplicare

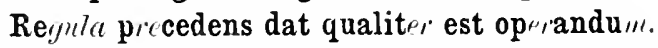

Digit lig divit is eily.

1 leaf $161 a$.

TI Ifue he teches a rewle as pon hast afore to multiplie a ligit be moper, as $\mathrm{yf}^{\mathrm{f}}$ pou wolle wete cwat is sex tymes 6 . pon ${ }^{1}$ sehalt wete liy pe rewle pat I tazt pe before, yf pou hane mymle perof.

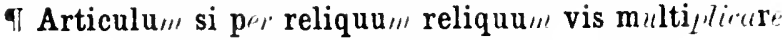

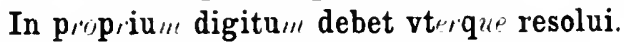

Tा Articulus digitos post se multiplicantes

Ex digitus quociens retenerit multipli $\cdot$ cr $i$

Articuli faciu $/$ t tot centu $/ \prime$ m $n$ ltiplicati.

Tl:e fist rave of tlie cratit.

Article lis. article;

another exaniple:

${ }^{2}$ lexf $161 \mathrm{~b}$. linuly thes ben in 20 tymes $30^{2}$, perefure 20 tymes 30 is 6 hun- 32 Jryth euend. loke $\&$ se. I But yf it be so pat one articul be withInne an humbryth, or by-twene an hundryth and a thowsande, so pat it be not a bowsimle fully. pen loke how mony vinytes ben in pe nounbur pat comys of pe multiplicaciond ${ }^{3}$ And so mony tymes 36 of 2 digittes of yllie articuls, so mony thowsant ben in pe nounbre, the awych comes of pe multiplicacions. And so mony tymes ten

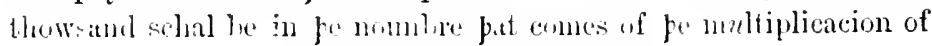

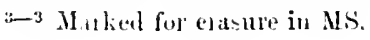


2 articuls, as yf pou woll wete qwat is 4 humdiyth tymes [two hundryth]. Multiply 4 be $2,{ }^{1}$ pat wol be 8 . in 8 ben 8 vinites. T And so mony tymes ten thonsand be in 4 hundryth tymes Mlentalmulti$t[2]^{1}$ hundryth, pat is 80 thonsand. Take hede, I schall telle pe a generalle rewle whan pou hast 2 articuls, Anl pou wold wete ciwat Anuther excomes of pe multiplicacion of hem 2. multiplie pe digit of pat on articuls, and kepe pat nounbre, pen loke how mony cifers schuld go $s$ before pat on articuls, and le were write. Als mony cifers selunld go hefore pat other, \& he were write of cifers. And have alle pe ylke cifers toged $u$. in fi mynde, ${ }^{2}$ a-rowe ychon aftur other, and 2 teaf $162 a$. in fe list plase set pe nounbre pat comes of pe multiplicacion of pe 12.2 digittes. And loke in pi mynde in what place he stondes, where in pe secuule, or in pe thryil, or in pe 4 , or where ellis, and loke qwat fe tigures by-token in pat place; $d$ so mych is pe nounbre pat comes of pe 2 articuls $y$-multiplied to-gerl $u$ as pus: yf pou wold smother ex16 wete what is 20 thousant tymes 3 powsande. multiply pe digit of pat articulle pe quych is 2 hy pe digitte of pat oper articul pe quych is 3 , pat wol be 6 . pen luke how mony cifers schal go to 20 thonsant as lit schuld he write in a talul. certainly 4 cifers schnld go to $20: 0$ powsant. ffor pis figure 2 in pe fyrst place hetokenes twene. - In pe secunde place lit betokenes twenty. Ii In pe 3. place lit Notation. betokenes 2 limilrytl. . . In pe 4 place 2 thousant. II In pe 5 place hit betukenes twenty pousmit. perefore he most have 4 cifers 24 a-fore hym fat he may stonde in pe 5 place. kepe pese 4 cifers in thy mynde, pen loke how mony cifers gon to 3 thousant. Certayn to 3 thousante ${ }^{3}$ gon 3 cifers afore. Now cast ylke 4 cifers pat ${ }^{3}$ leaf $16: b$. cchuld go to twenty thonsant, And thes 3 cifers pat schull go 28 afore 3 thousant, \& sette hem in rewe ychon after oper in pi mynule, as pai seluuld stonde in a tabulle. And peu schal pou hane 7 cifers; pen sett pat 6 pe quyclu comes of pe multiplicacion of pe 2 digittes aftur be ylke cifers in pe 8 place as yf pat hit storle in a 82 tabul. And loke qwat a figure of 6 scluuld betoken in pe 8 place. $\mathrm{yf}$ hit were in a tabul \& so myel it is. \& yf pat figure of 6 stonte in pe fyrst place he sehul! hetolien hut 6 . TIn pe 2 liace he sehuld hetoken sexty. I In the 3 place he sehuld betoken) sex humirytl. 36 T In pe 4 place sex thousant. T In pe 5 place sexty powsant. Nutation T In pe sext place sex hundryth powsant. If In pe 7 place sex fowsant thousantes. TI In pe $S$ place sexty powsant thousantes. ferfore sett 6 in octano loco, And he schal betoken sexty powsint

$$
14 \text { in MS. }
$$


Mental mul- thousantes. Ancl so mych is twenty powsant tymes 3 thousant, tiplication.

T And pis rewle is generalle for alle maner of articuls, Whethir pai be hundryth or powsant; but pou most know well pe eraft of pe 1 leaf $163 a$. wryrehynge in pe tabulle ${ }^{1}$ or pou know to do pus in pi mynde aftur pis rewle. Thou most pat pis rewle holdype note but where pere ben 2 artieuls and no mo of pe quych ayther of hem hase but on figure significatyf. As twenty tymes 3 thousant or 3 liundryth, and such opur.

T Articulum digito si multiplicare oportet

Articuli digit[i sumi quo multiplicate]

Debem $\iota$ seliquum quod multiplicat $\ldots$ ab illis

Per reliquo decuplu $m$ sic summa $"$ latere nequibit.

The tlitiod case of the cratt;

an example.

T Here he puttes pe thryde rewle, pe quych is pis. yf pou wel multiply in pi mynele, And pe Artieul be a digitte, pou sehalt loke pat pe digitt be with-Inne an hundryth, pen pou sehalt multiply the digitt of pe Articulle by pe oper digitte. And every vnite in pe 16 nounbre pat schalle come pere-of schal betoken ten. As pus: yf pat pou woll wete qwat is twyes 40 . multiplie pe digitte of 40 , pe quych is 4 , by pe oper diget, pe quych is 2 . And pat wolle be 8 . And in pe nombre of 8 ben 8 vnites, \& euery of pe ylke vnites 20 sehuld stonde for 10 . pere-fore pere sehal be 8 tymes 10 , pat wol be 4 score. And so mony is twyes 40. Tf If pe articul he a hundryth or be 2 liundryth And a powsant, so pat hit be notte a

2 leas 1636 . thousant, ${ }^{2}$ worch as pou dyildyst afore, sane pou schalt rekene enery 24 vnite for a hundryth.

II In numer ${ }^{\prime} m$ mixtu $n$ digitu $m$ si ducer $e$ cures Articul $n s$ mixti sumat $u r$ deinde resoluas

In digita $m$ post fac respectu de digitis

Articulusque docet excrescens in diriuando

In digitu $m$ mixti post ducas multiplica $/$ te $m$

II De digitis vt norma ${ }^{3}$ [docet] de [hunc]

Multiplica simul et sic postea summa patebit.

The fourth case of the craft:

Composite by digit.
Here he puttes pe 4 rewle, pe quych is pis: yf pou multipliy on composit be a digit as 6 tymes $24,{ }^{4}$ pen take pe diget of pat composit, \& multiply prit digitt by pat oper diget, and kepe pe nomlur pat comes prre-of. pen take pe digit of pat composit, \& multiply pat 36 digit by amoper diget, by pe quyeh pon hast multiplyed pe diget of pe articul, and loke qwat comes pere-of. pen take pou pat nombur, \& cast hit to pat other nounbur fat pou secheste as pus yf pou wol 3 docet. decet MS. 4 ' 4 times 4 ' in MS. 
wete qwat comes of 6 tymes $4 \&$ twenty. multiply pat anticulle of Mental muspe composit by pe digit, pe quych is 6 , as yn pe thryel rewle pou was tauzt, And bat schal be 6 score. pen multiply pe diget of pe 4 composit, 'pe quych is 4, and multiply pat ly pat other diget, pe 1 leaf 164 a. quych is 6 , as pon wast tauzt in pe first rewle, $y$ f fou haue mynde perof, $\&$ pat wol be $4 \&$ twenty. "east all ylke nomburs to-gredir, \& hit schal be 144. And so mych is 6 tymes $4 \&$ twenty.

I Ductus in articulum numerus si compositus sit

Articulum purum comites articulum quo $m u e$ Mixti pro digitis post fiat [et articulus $v \mathrm{t}$ ] Norma iubet [retinendo quod extra dicta ab illis]

Articuli digitu $m$ post tu mixtum digitu $m$ duc

Regulu de digitis nec precipit articulusque

Ex quibus excrescens summe tu iunge priori

Sic manifesta cito fiet tibi summa petita. - Here he puttes pe 5 rewle, pe quych is pis: yf pou wel The fifh case multiply an Articul be a composit, multiplie pat Articul ly be articul of pe composit, and worch as pou wos tauzt in pe secunde rewle, of pe quych rewle pe verse begynues pus. I Articulum si Article hy $20 \mathrm{p} \rho$. Relicum vis multiplicare. pen multiply pe diget of pe composit by pat opir articul aftir pe doctrine of pe 3 rewle. take perof gode hede, I pray pe as pus. Yf pon wel wete what is 24 tymes ten. Multiplie ten by 20 , pat wel be 2 lumblyth. pen multiply pe diget an example. $2 t$ of pe 10 , be quyeh is 1 , by pe liget of pe eomposit, pe quy ch is 4 , $\&$ pat 2 wol be 4 . pen reken enery vnite pat is in 4 for $10, \&$ pat 2 leaf $164 b$. schal be 40 . Cast 40 to 2 hundryth, \& patt wol be 2 hunchyth \& 40 . And so mych is 24 tymes ter.

9 Compositum numer $\mathbf{u} m$ mix to si[c] multiplicabis Vndecies tredecim sic est ex hiis operandum

In reliquum primmn demu $m$ duc post in eundem Vnum post den $/ \mathrm{m}$ duc in tria deinde per vnum Multiplices $q u e$ dem $u$ m int $r^{\prime} \iota$ ornnia multiplicata In summa decies quam si fur it tili doces Multiplicandor $m$ de normis sufficiunt hee.

T Here lie puttes be 6 rewle, $\&$ pe last of alle multiplicacion, The sixth case 36 pe quych is pis: yf pou wel mnltiplye a composit by a-noper composit, pon schalt do pus. multiplie pat on composit, qwych pou welt composife hy of the twene, by pe articul of pe toper composit, as pou were tauzt in be 5 rewle, fen multiplie pat sime composit, pe quycl pou last $40 \mathrm{multiplied} \mathrm{by} \mathrm{pe} \mathrm{ober} \mathrm{articul,} \mathrm{by} \mathrm{pe} \mathrm{ligit} \mathrm{of} \mathrm{pe} \mathrm{ofer} \mathrm{composit,} \mathrm{as}$ 
Mental mul. pou was tauzt in pe'4 rewle. As pus, yf pou wold wete what is 11 an example tymes 13 , as pou was tauzt in pe 5 rewle, $\&$ pat schal be an lum. dryth \& ten, afterwarde multiply pat same composit pat pou hast multiplied, pe quych is a.11. And multiplye lit be pe digit of pe 4 oper composit, pe quych is 3 , for 3 is pe digit of 13 , And pat wel be 30 . pen take pe dirit of pat composit, pe quych composit pou ' leaf $16 \bar{s} a$. multiplied by pe digrit of pat oper composit, ${ }^{1}$ pe quych is a 11 . I Also of pe quych 11 on is pe digit. multiplie pat dicitt by pe $z$ crath. ligett of pat other composit, pe quycl diget is 3 , as fou was tauzt in pe first rewle in be begynnynge of pis craft. pe quych rewle begynnes "In digitum cures." And of alle pe multiplicacion of pe 2 digitt comys thre, for onys 3 is but 3 . Now cast alle pese nounhers 12 togedur, the quych is pis, a hundryth \& ten $\& 30 \& 3$. And al pat wel be 143 . Write 3 first in pe ryglit side. And east 10 to 30 , pat wol be 40 . set 40 next aftur towarde pe lyft side, And set aftur a luundryth as here an Ensampulle, 143.

(Cetera rlesunt.) 


\title{
The Adt of Allombrung.
}

\author{
A TRANSLATION OF
}

\section{Join of 3lolumood's 四e Arte Numerandi.}

[Aslmole Ms: 396, fol. 48.]

B

oys seying in the begynnyng of his Arsemetrik :-Alle thynges that bene fro the first begynnyng of thynges have prncedede, and come forthe, And by resoun of nombre ben formede; And in wise as they ben $e$, So owethe they to be knowene; wherfor in vniuersall $\rho$ knowlechyng of thynges the Art of nombrynge is best, and most operatyfe.

T' herfore sithen the science of the whiche at this tyme we intendene to write of standithe alle and about nomline: The name of ffirst we most se, what is the propre name therofe, anll fro Fol. 49. whens the name cone: Afterwarde what is nombre, And how manye spices of nombre ther ben. The name is clepede Algorisme. 12 hale out of Algore, other of Algos, in grewe, That is clepicle in perination of englisshe art other craft, And of Rithmus that is callecle nombre. So algorisme is clepele the art of nombryng, other it is had ofe en or in, and gogos that is introduccionn, and lithmus nombre, that is another. 16 to say Interduccion of nombre. And thirdly it is hade of the name of a kyng that is clepeete Algo and Riythmus; so callede Algorismes. Sothely .2. manere of nombres ben nuthied"; Formalle, ${ }^{1}$ as nombre is vnitees gadrecle to-grelles; Materialle, ${ }^{2}$ as another. 20 nombre is a colleccioun of rnites. Other nombre is a multitule harde out of vnitees, rnitee is that thynge wher-hy enery thynge is cillede none, other o thynge. Of nombres, that one is eleped digitalle, that othere Article, Another a nombre componcte oper 24 myxt. Another digitalle is a nombre with-in.10.; Article is put tiuld of nombre that may be dyvydude in .10. parties egally, And that there 
leve no resilur: Componerle or medlede is that nombre that is come of a dirite and of an article. And rnchestanle wele that alle nombres betwix. 2. articles next is a nombre componele. Of this

The 9 rules of the Art.

1 Ful. $48 b$

Figures, lifferences places, and fimits.

traccioun, Mediacioun, Inulacioun, Multipliacioun, Dyrysioun, Progressioun, And of Rootes the extraccioun, and that may le hade in 2. maners, that is to sey in nombres qualiat, and in cubices: Amonge the whiche, ffirst of Numeracioun, and afterwarle of pe 8 oper's by ordure, y entende to write.

\section{${ }^{1}$ For-sothe numeracioun is of euer's numbre by competent figures an artificialle representacioun.}

$O^{\circ}$ othly figure, difference, places, and lynes supposen o thyng 12 other the same, But they ben sette here for lyuers resons. ffigure is elepede for protraccioun of figuracioun ; Difference is callede for therby is shewele euery figure, how it hathe difference fro the figures before them : place by cause of space, where-in me 16 writethe: lynees, for that is ordeynede for the presentacioun of The 9 figures. enery figure. And vnlerstoncle that ther ben .9. lymytes of figures that representen the 9. ligites that ben these. 0.9 .8 . 7.6 . The cipher. 5. 4. 3. 2. 1. The .10. is cleprecle theta, or a cercle, otler a cifre, 20 other a figure of nought for nought it signyfiethe. Nathelesse she hollyng that place givethe others for to signyfie; for withe-ont cifre or cifres a pure article nay not be writte. And sithen that by The numera- these .9. figures signiticatifes Ioynecle with cifre or with cifres alle it tion nombres beu and may be representede, It was, nether is, no nede to of digits, fynde any more figures. And note wele that every digite shalle be writte with oo figure allone to it aproprede. And alle articles by of articles, a cifre, for euery article is namede for oone of the digitis as .10. of 28 1.. 20. of. 2. and so of the others, \&c. And alle nombres digitalle owen to be sette in the first difference: Alle articles in the seconde. Also alle nombres fro .10. til an .100. [which] is excludede, witl .2. figures mvst be writte; And $y f$ it be an article, by a cifre first put, 32 and the figure $\mathrm{y}$-writte towarle the lift honde, that signifiethe the digit of the whiche the article is namede; And yf it be a nombre of compo- componede, ffirst write the digit that is a part of that componede, sites. and write to the lift sile the article as it is seile be-fore. Alle 36 nombre that is fro an hundrede tille a thousande exclusede, owithe to be writ by .3. figures; and alle nombre that is fro a thousande 
til .x. Mt. must he writ by .4. figures; And so forthe. And vinterstonle wele that enry fignese sette in the first place signyfiethe his The value dirit; In the seconte place.10. tymes his digit; In the .3. place an tion.

4 hundred, so moche; In the .t. place a thousande so moehe; In the .5. flace .x. thousande so mocle; $1 \mathrm{n}$ the .6. place an hundrede thousande so moche; In the .7. place a thousande thousande. And so infynytly moltiplying by 'these .3. 10, 100, 1000. And vnder1 Fol. 19. S stancle wele that competently me may sette vpon figure in the place of a thousande, a prike to shewe how many thousande the last figure shalle represent. We writene in this art to the lift side-warle, as Numbers are arabiene writene, that weren fynders of this science, othere for this riglit to left. 12 resoun, that for to kepe a custumable ordre in redyng, Sette we alle-wey the more nombre before.

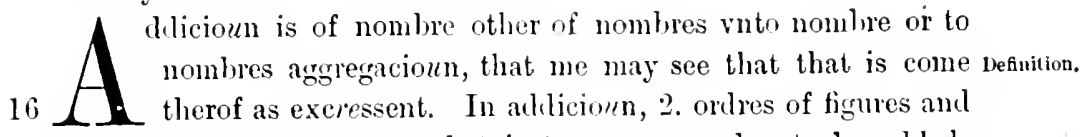
.2. nombres ben necessary, that is to sey, a nombre to be atdede and the nombre wherto the addicioun slolde be made to. The nombre to be addede is that pat sholde be addede therto, and shalle 20 be vulerwiten; the nombre vnto the whiche addicioun shalle be male to is that nombre that resceynethe the addicion of pat other, and shalle be writen above; and it is convenient that the lesse How the nombre be vnderwrit, and the more adlede, than the contrary. nliould be 24 But whether it happe one other other, the sime conythe of, Therfor, yf pow wilt adde nombre to nombre, write the nombre wherto the addicioun shalle be made in the omest ordre by his differences, so that the first of the lower ordre be vudre the first 28 of the onyst ordre, and so of others. That done, alde the first of The melhod the lower ordre to the first of the omyst ordre. And of suche aldicioun, other pere growith therof a digit, An artiele, other a composede. If it be cligitus, In the place of the omyst shalt thow Begin at the 32 write the digit excrescyng, as thus :-

\begin{tabular}{|c|c|c|}
\hline The resultant & 12 & in the place of th \\
\hline To whom it shal be addede & 1 & omyst jut a-way ly a cifre. writte, \\
\hline The nombre to be adtlede & 11 & 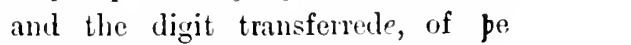 \\
\hline
\end{tabular}

36 whiche the article toke his name, towarle the lift side, and he it addede to the next figure folowyng, yf ther be any fignue folowyng; or no, and yf it be not, leve it [in the] voide, as thus:- 
or an article,

\begin{tabular}{|l|c|}
\hline The resultant & 10 \\
\hline To whom it shalle be added $e$ & 7 \\
\hline The nombre to be addede & 3 \\
\hline
\end{tabular}

\begin{tabular}{|l|l|l|l|l|l|}
\hline Resultans & 2 & 7 & 8 & 2 & 7 \\
\hline Cui debet addi & 1 & 0 & 0 & 8 & 4 \\
\hline Numeres addendus & 1 & 7 & 7 & 4 & 3 \\
\hline
\end{tabular}

And yf it happe that the figure folowyng wherto the addicioun shalle be male by [the cifre of] an article, it sette a-side; In his

1 Fol. 49b. place write the ${ }^{1}$ [aligit of the] Article as thus :-

\begin{tabular}{|l|l|}
\hline The resultant & 17 \\
\hline To whom it shalle be added $c$ & 10 \\
\hline The nombre to be adderle & 7 \\
\hline
\end{tabular}

And yf it happe that a figure of .9 . by the figure that me mvst adde [one] to, In the place of that 9. put a cifre and write pe article towarde be lift honde as bifore, and thus:-

\begin{tabular}{|l|r|}
\hline The resultant & 10 \\
\hline To whom it shalle be addede & 9 \\
\hline The nombre to be addede & 1 \\
\hline
\end{tabular}

or a compo. And $\mathrm{f}^{2}$ [therefrom grow a] nombre componed, ${ }^{3}$ [in the place of site. the nombre] put a-way ${ }^{4}$ [let] the digit [be $]^{5}$ writ pat is part of pat composide, and pan put to pe lift $\mid$ The resultant $|12|$

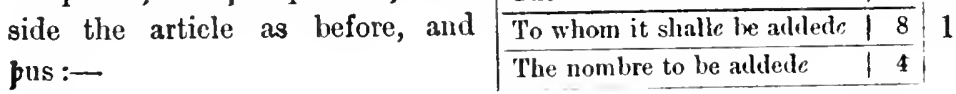

This done, adde the seconcle to the seconcle, and write above oper as before. Note wele pat in addicions and in alle spices folowyng, whan he seithe one the other shalle be writen aboue, and me most 16 vse ener figure, as that every figure were selte by halfe, and by hym-selfe.

Defunition of Suberaction.

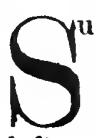

yubtraccioun is of .2. proposede nombres, the fyndyng of the excesse of the more to the lasse: Other subtraccioun is 20 ablacioun of o nombre fro a-nother, that me may see a some left. The lasse of the more, or even of even, may be withdraw; How it my The more fro the lesse may neuer be. And sothly that nombre is be done. more that hathe more figures, So that the last be signyficatifes: 24 And yf ther ben as many in that one as in that other, me most deme it by the last, other by the next last. More-oner in withwhat is re-- drawyng .2. nombres ben necessary; A nombre to be withdraw, quired. 1 And a nombre that me shalle with-draw of. The nombre to be 28 with-draw shalle be writ in the lower ordre by his differences; The

$$
3 \text { 'the' in MS. } \quad \text { ' 'be' in MS. ' 'and' in MS. }
$$


nombre fro the whiche me shalle withe-draw in the omyst ordre, Write the so that the first be vinder the first, the secomle vuder the seconde, ber abure.

And so of alle others. Withe-draw therfor the first of the lowere suluract ine 4 ordre fro the first of the ordre above his hede, and that wolle be if possible.

other mure or lesse, oper egalle.

$\mathrm{yf}$ it he egalle or even the figure

sette beside, put in his place a

8 eifre. And yf it be more put awily

\begin{tabular}{|l|r|}
\hline The remanent & 20 \\
\hline Wherof me shalle withliaw & 22 \\
\hline The nombre to be withliaw & 2 \\
\hline
\end{tabular}

perfro als many of vitees the

lower figure conteynethe, and writ the resilue as thus

12

\begin{tabular}{|c|c|c|c|c|c|}
\hline Remanens & $2|2| 1 \mid 8$ & & 9 & 9 & 9 \\
\hline A yno sit subtraecio & 8171214 & 3 & 0 & 0 & \\
\hline Numerus subtrahemlus & $6 \mid 5]^{2} \mid[6]$ & & . & . & \\
\hline
\end{tabular}

\begin{tabular}{|l|r|r|}
\hline The remanent & 2 & 2 \\
\hline Wherof me shalle with-draw & 2 & 8 \\
pe nombre to be withdraw & 16
\end{tabular}

And $y f$ it be lesse, by-eause if it is not the more may "borrow ten, not be with-

16 draw ther-fro, borow an vnyte of the next figure that is worthe 10 . Of that .10. and of the figure that ye wohle have with-draw fro be-fore to-gedre Ioynede, with-draw pe figure be-nethe, and put the and then subresidne in the place of the figure

20 put a-siile as pus:-

And yf the figure wherof me

\begin{tabular}{l|l|l|}
\hline The remanent & 1 & 8 \\
\hline Wherof me slialle with-llaw & 2 & 4 \\
The nombre to be with-llraw & 0 & 6
\end{tabular}

shal borow the vinyte be one,

If the second figure is one. put it a-sitle, and write a cifre in the place perof, lest the figures 24 folowing faile of thaire nombre, and pan worche as it shewith in this figure here:-

And yf the vnyte wherof me shal borow be a cifre, go

28 ferther to the figire signy-

\begin{tabular}{|c|c|c|}
\hline The remanent & $|\overline{3 \mid} 0| 9$ & $\begin{array}{l}\text { If the secon.l } \\
\text { tigure is a }\end{array}$ \\
\hline Wherof me slial with-draw & $|3| 1|2|$ & \\
\hline The nombre to be with-draw & $|1| 3$. & \\
\hline
\end{tabular}

ficatife, and ther borow one, and retoumyng bake, in the place of euery cifre pat ye lasside oner, sette figures of .9 . as here it is speeifiede:-

32 And whan me comethe to the nombre wherof me intendithe, there re-

\begin{tabular}{|l|l|l|l|l|l|}
\hline The remenaunt & $|2| 9$ & 9 & 9 & 9 \\
\hline Wherof me shalle with draw & 3 & 0 & 0 & 0 & 3 \\
\hline The nomlure to be with-draw & $\mid$ & $\mid$ & $\mid$ & 4 \\
\hline
\end{tabular}
maynethe alle-wayes .10. ffor pe whiche .10. \&c. The reson why A justifica. 36 pat for enery cifre left behynde me setteth figmres ther of .9. this it rule given. is:-If fro the .3. place me borowede an vnyte, that vnyte hy respect of the figure that he eame fro representith an .C., In the

26 in MS. $\quad 30$ in MS. 
place of that cifre [passerl over] is left .9., [which is worth ninety], and yit it remaynethe as 10. , Anl the same resone wolle be $y f$ me hade horowede an vayte fro the .t., .5., .6., place, or ony other so vpwarde. This done, withdraw the seconde of the lower ordre fro the figure above his hede of pe omyst ordre, and wirche

Why it is better to right to left.

\section{Llow to jirove} sibtraction, as before. And note wele that in adlicion or in subtraccioun me may wele fro the lift side hegynne and ryn to the right side, But it wol be more poofitabler to be do, as it is taught. And yf thow wilt prove yf thow have do wele or no, The figures that thow hast withdraw, adde them ayene to the omyst figures, and they wolle accorde with the first that thow haddest $y$ f thow have labored andadition. wele; and in like wise in addicioun, whan thow hast addede alle 12 'Fol. $50 u$. thy figures, withlraw them that thow first laddest, and the same wolle retoume. The subtraccioun is none other but a pronffe of the aldieioun, and the contrarye in like wise.

Defiution of mediation.

Where to begin.

If the first figure is unity.

Whiat to do if it is nout unity.

Then halve the second figure.

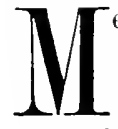

etlacioun is the fyndyng of the halfyng of ene'y nombre, 16 that it may be serne what and how moche is enery halfe. In halfyug ay oo order of figures and oo nombre is necessary, that is to sey the nombre to be halfecle. Therfor yf thow wilt half any nombre, write that nombre ly his differences, and 20 begynne at the right, that is to sey, fro the first figure to the right side, so that it be signyficatife other represent vnyte or eny other digitalle nombre. If it be vnyte write in his place a cifre for the figures folowyng, [lest they sionify less], and write that vnyte 24 withont in the table, other resolne it in .60. mynvtes and sette aside half of tho minutes so, and reserve the remenaunt without in the table, as thus .30.; other sette withont thus ort that kepethe none ordre of place, Nathelesse it hathe signyficacionn. And yf 28 the other figure signyfie any other digital nombre fro vnyte forthe, oper the nombre is ode or evene. If it be even, write this half in this wise :And if it be orlde, Talke the next even vulde Halfede $\frac{|2| 2}{|+1| 4}$ hym conteynede, and put his half in the place of that odle, and of pe vingte that remaynethe to be halfede do thins:This done, the seconde is to be lialfede, $\mathrm{yf}$ \begin{tabular}{|l|l|l|l}
\hline halfede $\quad|2| 3 \mid$ & [li $]$
\end{tabular} it be a cifre put it be-side, and $\mathrm{y}^{\mathrm{f}}$ it be significatife, other it is even or wle: If it be even, write in the place of pe nombres wiperle out the halfe; $y$ it be ode, take the next even rinder it contenythe, and in the place of the Impar sutte a-side put half of the even: The 40 
vingte that remaynethe to be halfede, respect hade to them before, is worthe .10 . Dyvide that $.10 . \mathrm{in} .2 ., 5$. is, and sette a-sicle that If it is oudd, one, and alde that other to the next figure

4 precedent as here:-

And yf pe addicioun sholte be made to a cifre,

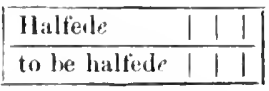
tigure before.

sette it a-side, and write in his place .5. And vmler this fourme me shalle write and worche,

8 tille the totalle nombre he halferle.

\begin{tabular}{|c|c|}
\hline loublede & $8|9| 0|10| 17 \mid 4$ \\
\hline to be doublesle $|1| 3$ & $4|4| 5$ \\
\hline
\end{tabular}

\section{2}

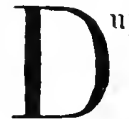

uplicacioun is agrugacion of nombre [to itself] pat me may se Defuition of the nombre growen. In doublynge ay is but one ordre of figures necessarie. And me most be-igynne with the lift side, other of the more figure, And after the nombre of the more figure representithe. 'In the other. 3 . before we begynne alle way 1 Ful. 51. fro the right side and fro the lasse nombre, In this spice and in alle Whene 16 other folowyng we wolle begynne fro the lift sile, flor and me bigon the clouble fro the first, omwhiie me myght double wo thynge twyes. And how be it that me myght double fro the right, that why. wolde be harder in tecliyng and in workyng. Therfor yf thow 20 wolt double any nombre, wite that nombre by his differences, and donble the last. Anl of that doublyng other growithe a nombre digital, article, or componede. [If it be a digit, write it in the place of the first ligit.] If it be article, write in his place a eifre 24 and transferre the article towarle the lift, as

thus :-

And $y$ the nombre be componede, write a

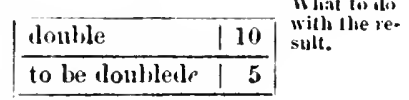
digital that is part of his composicioun, and sette the article to the 28 lift hand, as thus :\begin{tabular}{l|l|l|}
\hline That done, me most donble the last save one, & lonble & 16 \\
\hline to be donblete & 8 \\
\hline
\end{tabular} biiplation. before. And yf a eifre be, touele it not. But yf any nombre 32 shalle be addede to the eifre, in pe place of pe figure wipede out me most write the nombre to be addede, as thus :-

In the same wise me shalle wirche of

\begin{tabular}{|l|l|l|l|l|}
\hline loublede & 10 & 0 & 0 & 6 \\
\hline to be donblede & 3 & 0 & 0 & 3 \\
\hline
\end{tabular}

36 alle others. And this probacioun : If thow truly double the halfis, llow woun prowe and truly half the doubles, the same nombre and figure shalle mete, suche as thow labourele rpone first, And of the

\begin{tabular}{|l|l|l|l|}
\hline Doublede & 6 & 1 & 8 \\
\hline to be doublede & 3 & 0 & 9 \\
\hline
\end{tabular}
40 contrarie. 
Definilion of Multiplication.

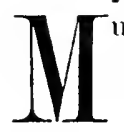

ultiplicacioun of nombre by hym-self other by a-nother, with proposile .2. nombres, [is] the fyndyng of the thirde, 'That so oft conteynethe that other, as ther ben rinytes in the oper. In multiplicaciom .2. nombres pryneipally ben necessary, that is to sey, the nombre multiplying and the nombre to he Iultiplier. multipliade, as here;-twies fyve. [The number multiplying] is desirnede aduenlially. The nombre to be multipliele resceyvethe suntiplicand. a nomimalle appellacioun, as twies .5. 5. is the nombre multipliede, 8 and twies is the nombre to be multipliedle.

\begin{tabular}{|c|c|c|c|c|}
\hline Resultans & $111|0|$ & $1|3| 2 \mid$ & $6|6| 8$ & \begin{tabular}{l|l|l}
0 & $0 \mid 8$
\end{tabular} \\
\hline Multiplicandus & 1.1 .15 & .1 .14 & $.13 \mid 4$ & $0|0| 4$ \\
\hline Multiplicans & 1.1212 &.$|3| 3$ & 21212 & .1 .1 \\
\hline
\end{tabular}

Proinc. Also me may thervpone to assigne the. 3. nombre, the whiche is

2 Fol. si $\iota$. 2 clepede product or provenient, of takyng ont of one fro another: as tivyes .5 is $.10,5$. the nombre to be multiplied", and .2. the 12 multipliant, and. 10. as before is come therof. And vnderstonde wele, that of the multipliant may be male the nombre to be numtipliede, and of the contrarie, remayuyng ener the same some, and herof comethe the comen speche, that seithe all nombre is convertede hy Multiplying in lym-selfe.

There are 6 rules of Mil. liplicition.

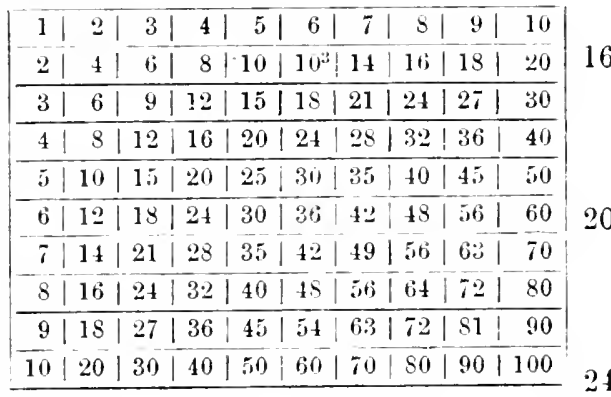
(1) higit by ligit, consille how many of rnytees ben betwix the digit by multi-
digit. plying and his .10. Jyethe to-grelre accomptede, and so oft with-dlaw the digit multiplying, vnler the article of his denominacionn. Example of grace. If thow wolt wete how moche is .t. tymes .8., 28 ${ }^{4}$ se how many ruytees ben hetwix .8.5 and .10. to-greter rekenede, amel it slewith thit. .2. : withdraw ther-for the quaternary, of the article of his lenominacion twies, of .40., And ther remaynethe

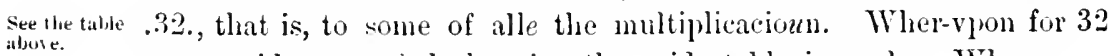
more evidenee and declaracion the seide table is made. Whan a

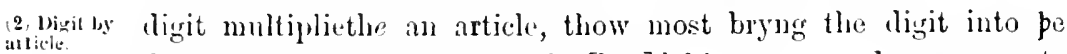
dicit, of pe whiche the article [has ${ }^{6}$ his name, and enery rnyte

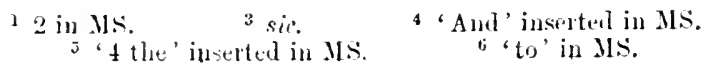


shalle stonde for .10., and euery article an .100. Whan the digit (3) composite multipliethe a nombre componem, pon most bryng the digit into hy digit.

aiper part of the nombre componede, so pat digit be hal into digrit 4 by the first rule, into an article by pe seconcle rule; aml afterwarle

Ingne the produccioun, and pere wol be the some totille.

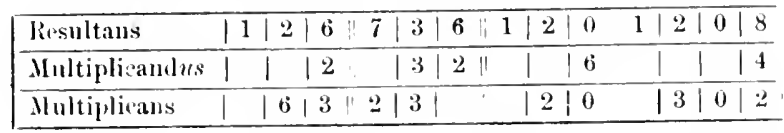

Whan an article multipliethe an article, the ligit wherof he is it anticle ly namede is to be bronght Into the digit wherof the uper is namede, 8 and every vnyte wol be wortle 'an .100., ant enery article. a 1 Fol. s.. .1000. Whan an article multipliethe a nombe componecle, thow s; composite most hryug the digit of the article into aither part of the nombre componede; and Ioyne the prinlnceion, and enery article wol he 12 worthe 100 , and enery vayte .10 , and so wolle the some be opene. Whan a nombre componede multipliethe a nombre com- o compisite ponede, encig prert of the nombre multiplying is to be lanle into enery part of the nombre to be multipliede, and so shalle the digit

16 be hald twies, onys in the digit, that other in the article. The article also twies, ones in the digit, that other in the article. Therfor $y$ f thow wilt any nombre hy lym-self other by any other nultiplie, write the nombre to be multipliede in the oner ordre by 20 his differences, The nombre multiplying in the lower ordre ly his llow to sel lifferenees, so that the first of the lower ordre be vnder the last of numbers. the oner ordre. This clone, of the multiplying, the last is to he hade into the last of the nombre to be multiplierle. Wherof than 24 wolle grow a digit, an article, other a nombre componerle. If it be riche result a cligit, even above the figure multiplying is liede write his digit that come of, as it apperethe here:-

\begin{tabular}{|c|c|}
\hline The veoultant & 16 \\
\hline 'To lu luultiplicele & 3 \\
\hline
\end{tabular}

And yf an article had be writ one, the figure multiplying his heele, an article. 28 put a cifre pes and transferre the article towarle the lilt hande', as tlius :-

\begin{tabular}{|l|l|l|}
\hline The resultint & 1 & 0 \\
\hline to be multipliede & 15 \\
\hline be nombre multipliyng & & 12 \\
\hline
\end{tabular}

And yf a nombre componete be writ oue the figme multylying is or a compohede, write the digit in the nombre componede is place, and sette 32 the article to the lift hancle, as thus:- 
Multiply nex by the last but one, and so 011 .

This done, me nust bryng the last save one of the multipliyng into the last of pe nombre to be multipliede, and se what comythe therof as before, and so do with alle, tille me come to the first of the nombre multiplying, that must be bronglit into the last of the nomise to be multipliede, wherof growithe oper a digit, an article,

1 Ful. 52 b. ${ }^{1}$ otlier a nombre componele. If it be a digit, In the place of the onerer, sette a-side, as here:

\begin{tabular}{|l|l|l|}
\hline Resultant & 6 & 6 \\
\hline to be multipliede & | & 3 \\
\hline the nombre multipliyng & 2 & 2 \\
\hline
\end{tabular}

If an article happe, there put a cifre in his place, and put hym to the lift hande, as here:

If it be a nombre componede, in

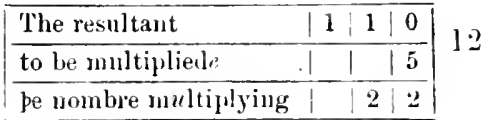

the place of the onerer sette a-side, write a digit that ${ }^{2}$ is a part of the componede, and sette on the left honde the artiele, as here:

Then antery Thiat done, sette forwarde the the multiplier figures of the nombre multiplying
onte plice.

\begin{tabular}{|c|c|}
\hline The resultant & $|1| 3^{3} \mid 2$ \\
\hline to be multipliede & \\
\hline & $3 \mid 3$ \\
\hline
\end{tabular}

by oo difference, so that the first of the multipliant be vnder the 20 last save one of the nombre to be multipliede, the other by o place sette forwarle. Than me shalle brynge the last of the multipliant in lyym to be multipliede, vnder the whiche is the frrst multipliant.

work as be. And than wolle growe oper a digit, an article, or a componede 24 forte. nombre. If it be a digit, adile hym even above his hede; If it he an article, transferre hym to the lift side; And if it Le a nombre componed", alde a digit to the figure above his hede, and sette to the lift hande the article. And alle-wayes enery figme of the 28 nombre multipliant is to be bronght to the last save one nombre to be multipliede, til me come to the first of the multipliant, where we shalle wirehe as it is seide before of the first, and afterwirde to put forwarde the fignres by o difference and one tille they alle be 32 How lodeal multipliede. And $\mathrm{y} f$ it happe that the first figure of pe multiwith cipliers, 1)liant be a cifre, aml boue it is sette the figure signyficatif $"$, write a eifre in the plice of the figmre sette a-sile, as thus, etc.:

\begin{tabular}{|l|l|l|l|}
\hline The resultant & 1 & 2 & 0 \\
\hline to be multipliede & & & 6 \\
\hline the mnltipliant & 1 & 2 & 0 \\
\hline
\end{tabular}

$\because$ 'that' repeated in $\mathrm{MS}$.

3 ' 1 ' in MS. 
And yf a cifre hajpe in the lower order be-twix the first and the list, and even above be sette the figne signyficatif, leve it rn- How to deal toncherlo, as here:-

4 . Ind yf the space above sette be roide, in that place white thow a cifre. Aml yf the cifre happe

\begin{tabular}{|c|c|c|c|c|}
\hline l'he result:unt & 2 & $2 \mid 6$ & & \\
\hline To be unltipliede & & 2 & & 2 \\
\hline The multipliant & 1 & $0 \mid 2$ & & \\
\hline
\end{tabular}

betwix pe first and the last to be multipliele, me most sette 8 forwarle the ordre of the figures by thaire differences, for oft of duceion of figures in cifres nought is the resultant, as here, ${ }^{1}$ wherof 1 Fol. 53. it is evident and open, yf thint the first figure of the nombre be 12 to be multiplied be a cifre, vulir it shalle be none sette as here:-

\begin{tabular}{|c|c|}
\hline Resultant & $8|0| 0|8|$ \\
\hline to le multiplieds & $| \pm| 0|0| 4 \mid$ \\
\hline the multipliatut & .1. \\
\hline
\end{tabular}

$16 \quad$\begin{tabular}{|l|l|l|l|}
\hline Resultant & 3 & 2 & 0 \\
\hline To be multiplicele & I & 8 & 0 \\
\hline The multipliant & The & 4 \\
\hline
\end{tabular}

Vinder [stand] also that in multiplica- Leave rom ciom, divisioun, and of rootis the ex- rows of traceioun, competently me may leve a myrlel space betwix .2. ordres of figures, that me may write there what is come of aldyng other withe-drawyng, lest any thynge sholde be once-lippete and sette 20 out of mymle.

F

For to dyvyile no nombre by a-nother, it is of .2. nombres pro- Definilion of posede, It is forto depart the moder nombre into as many purtis as ben of inytees in the lit-se nombre. And note

24 wele that in makynge of dyrysion ther ben .3. nombres necessary : that is to sey, the nomlire to be dyrydede; the nombre dyvydyng Bisidend, aml the nombre exeant, other how oft, or quncient. Ay shalle the quotient. nomlure that is to he dyvyledle he more, other at the lest evene with 28 the nombre the dyrysere, $y$ f the nombre shall. be made by hole nomhres. Therfor $y$ f thow wolt any nombre dyvyde, write the How to set nombre to be dyryilede in pe onerer bordure ty his tifferences, the sum. dyvisere in the lower ordure by his differences, so that the last of 32 the dyviser he vmiter the list of the nombre to be dyryde, the next last vuler the next last, and so of the others, $y$ it may competently be done; as liere:-

\begin{tabular}{|c|c|}
\hline The resilne & 11217 \\
\hline The quotient & 115 \\
\hline To be dyvyilede? & $131+12$ \\
\hline The dyvyser & $1|i| 3$ \\
\hline
\end{tabular}


Examples.

\begin{tabular}{|c|c|c|c|c|c|c|c|c|c|c|c|c|}
\hline Residuum & | & & 8 & & & & ii & 2 & $\tau$ & !! & & 6 \\
\hline Quociens & & 2 & 1 & 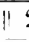 & 2 & 2 & 11 & & & ii & & 9 \\
\hline Divideudus & 6 & $|8|$ & 0 & ( & 6 & 6 & 3 & 4 & 2 & 113 & i 3 & 12 \\
\hline Diuiser & 3 & 2 & & & 3 & & & 6 & & 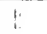 & 3 & 14 \\
\hline
\end{tabular}

When the dast of the
divisor must not be sel below llie last of the dividend.

${ }^{1}$ Fol. 5:2. sette. 'These so ordeynede, me most wirche from the last fignre of pe nombre of the dyryser, and se how oft it may be with-dlaw of Horlobegin. and fro the figure alowe his hede, namly so that the remenaunt may be take of so oft, and to se the resillue as here:-

\begin{tabular}{|c|c|c|}
\hline \multirow{4}{*}{ Au example. } & The resilue & $12 \mid 6$ \\
\hline & The quorient & 19 \\
\hline & To be ifyryalede & $3 \mid 3$ \\
\hline & 'Tlue dyviser' & $|3| 1$ \\
\hline
\end{tabular}

And note wele that me may not witho- 12 draw more thin .9. tymes nether lasse than ones. Therfor se how oft pe fignes of the lower ordre may be withdhaw fro the figures of the onerer, and the nombre that shewith pe 16 yuocient most be wit oner the hele of pat figure, vmler the whiche Where of the the tirst fignre is, of the lyviser; And hy that tigure me most withethe qunlieute draw alle oper figmes of the lower widir and that of the ligures abone thaire hedis. This so clone, me most sette forwarle fe figures 20 of the diniser ly o difference towards's the right honde and worche as before; and thus:-

Examples.

\begin{tabular}{|c|c|c|c|c|c|c|c|c|c|c|c|c|c|c|}
\hline liesidmun & ! & & | & 1 & & & & & & & & & 1 & 2 \\
\hline quociens & i & 1 & | & 6 & 5 & 4 & & & & & & 01 & 0 & 4 \\
\hline Dinidemdus & 3 & 5 & 5 & $1 \mid$ & 2 & 2 & 8 & & 8 & $\overline{i i}$ & & 7 & & 14 \\
\hline Einisor & 1 & $|5|$ & 4 & 31 & & & 4 & & 4 & 21 & 31 & & & 1 \\
\hline
\end{tabular}

\begin{tabular}{|l|l|l|l|l|l|l|}
\hline The quocient & & & & 6 & 5 & 4 \\
\hline To he dyvydede & 3 & 5 & 5 & 1 & 2 & 2 \\
\hline The dyvyser & & 5 & 4 & 3 & 1 \\
\hline
\end{tabular}

A special caser.

And $y$ if hape after pe setlyng forwarle of the ligures put pe last of the divisor may not so oft be withlaw of the figure above 24 his hell, ahove pat figure voler the which the first of the diuiser is writ me most sette a cifre in orlre of the nombre qnocient, and sette the figures forwarle as be-fore be o difference alone, and so me shalle do in alle nombres to be dyvidede, for where the dyviser may 28 
not be with-llaw me most sette there a cifre, and sette forwarle the figures; as here:-

\begin{tabular}{|c|c|c|c|c|c|c|}
\hline The resilue & 1 & & & & & 12 \\
\hline The quocient & T & & & 21 & $0 \mid 0$ & 4 \\
\hline To be dyryded $c$ & 18 & 8 & 6 & 3 & $7 \mid 0$ & 14 \\
\hline The dyvyser & 4 & 4 & 2 & 3 & 1 & 1 \\
\hline
\end{tabular}

Anl me shalle not cesse fro Another exsuclie settyng of figures forample.

neper of subtraccioun of the dyvyser, tille the first of the dyryser 8 be with-draw fro pe first to be dividede. The whiche done, or ourht, ${ }^{1}$ oper nought slialle remayne: and $\mathrm{yf}$ it be ought, ${ }^{3}$ kepe it in the taliles, And ener vay it to pe diviser. And yf pou wilt wete how many vnytees of pe divisioun ${ }^{2}$ wol growe to the nombre of the 12 divisere, the nombre quocient wol slewe it: and whan suclie divisioun is made, and fon lust prove yf thow lave wele done or no, Multiplie the quocient by the diviser, And the same figures How on prove wolle come ayene that thow hadilest bifore and none other. And 2 Fol. $53^{3}$. What the quotient how. $16 \mathrm{yf}$ ought be residue, than with aldicioun therof shalle come the same figures: And so multiplicacioun provithe divisioum, and dy visionn multiplicacioun : as thus, yf multiplicacioun be made, divide it or multiplicaby the multipliant, and the nombre quocient wol shewe the nombre lion.

20 that was to be multipliede, etc.

$\mathrm{P}$ rogressioun is of nombre after egalle excesse fro oone or tweyne Definition n. take agregacioun. of progressioun one is naturelle or conProgression. tymulle, pat opei broken and discontynuelle. Naturelle it

24 is, whan me hegynnethe with one, and kepethe orlure onerlepyng Natural pro. one; as .1. 2. 3. 4. 5. 6., etc., so pat the nombre folowynge passithe the other he-fore in one. Broken it is, whan me lepithe fro o nombre tille another, and kepithe not the contynuel ordire; as 1. 3. Bruken Pro.

28 5. 7. 9, etc. Ay me may begynne with .2., as pus; .2. 4. 6. 8., etc., gressiun. and the nombre folowyng passethe the others by-fore by .2. And note wele, that naturelle peogressioun ay begymethe with one, and Intereise or broken jerogressioun, omwhile begynnythe with one, 32 omwhile with twayne. Of progressioun naturell .2. rules ther be yove, of the whiche the first is this; whan the progressioun naturelle The ist rule endithe in even nombre, by the half therof multiplie be next totalle for Natural onevere nombre; Example of grace: .1.2. 3.4. Multiplie .5. by .2.

$3 \mathbf{b}$ and so.10. comethe of, that is the totallo nombre perof. The seconde rule is suche, whan the progressioun naturelle enclithe in nombre the second ode. Take the more porcioun of the odtes, and multiplie therby rule.

40 the totalle nombre. Example of grace 1. 2. 3. 4. 5., multiplie 
.5 . by .3 , and thryes .5. shalle be resultant. so the nombre totalle The first rule is .15 . Of progresionn intereise, ther ben also $.2{ }^{1}{ }^{1}$ 'ules; and pe if Brogression. first is pis: Whan the Intercise pogression endithe in even nombre by half therof multiplie the next nombre to pat halfe as .2. ${ }^{1} 4.6$. Multiplie.4. by .3. so pat is thryes .4., and .12. the nombre of alle The second the progressioun, wolle folow. The seconde rule is this: whan the rule. progressioun interscise enditle in ode, take pe nore porcionn of alle ${ }^{2}$ Fol. $3^{4}$. pe nombre, ${ }^{2}$ and multiplie by hym-selfe; as .1. 3. 5. Multiplie .3. 8 by hym-selfe, and pe some of alle wolle be .9 , etc.

The preamble if the extraction of roots.

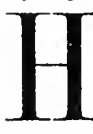
Tere folowithe the extraccioun of rotis, and first in nombre qualrates. Wherfor ne shalle se what is a nombre qualrat, and what is the rote of a nombre quadrat, and what it 12 is to draw out the rote of a nombre. And before other note

Linear, superficial antit solid nimber's.

Superficial numilers. this divisioun: Of nombres one is lyneal, anoper superficialle, anoper quadrat, anoper eubike or hoole. lyneal is that pat is considrede after the processe, havynge no respeet to the direceionn 16 of nombre in nombre, As a lyne hathe but one lymensioun that is to sey after the lengthe. Nombre superficial is put comethe of ledynge of oo nombre into a-nother, wherfor it is callede superficial, for it hathe .2. nombres notyng or mesurynge hym, as a 20 superficialle thynge hathe .2. limensions, put is to sey lengthe and brele. And for bycause a nombre may be hale in a-nother by .2. maners, pat is to sey other in liym-selfe, oper in anoper, Vndersquare mun- stonle $\mathrm{yf}$ it be had in hym-self, It is a qualrat. ffor dyvisioun 24 lops. write hy vnytes, hathe .4. siles even as a qualeangille. and $y$ f the nombre be hade in a-noper, the nombre is superficiel and not quadrat, as .2. hade in .3. makethe .6. that is pe first nombre superficielle; wherfor it is open pat alle nombre qualrat is snperfieiel, 28 The root of a and not conuertide. The rote of a nombre quallat is pat nombre

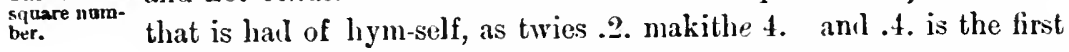
nombre qualrat, and 2. is his rote. 9. 8. 7.6.5.4.3.2. 1. / The Notes of snme rote of the more quadrat .3. 1. 4. 2. 6. The most nombre qualrat 32 exaunples of equare roots here interpolated. 9. 8. 7. 5. 9. 3. 4. 7. 6. / the remenent oner the quadrat .6. 0. S. 4. 5. The first cans of nombre quadrat .5. 4. 7. 5. 6. The rote .2. 3. 4. The seconde eaas.3. 8. 4. 5. The rote .6. 2. The thirde caas .2. 8. 1. 9. The rote .5. 3. The .4. ear .3. 2. 1. The rote 36 solid num. .1. 7./ The 5. caas .9. 1. 2. 0. 4./ The rote 3. 0. 2. The solicle nombre or cubike is pat pat comythe of double ledyng of nombre in nombre; And it is elepede a solide boty that hathe per-in .3

13 written for 2 in MS. 
[dimensions] pat is to sey, lengthe, brele, and thiknesse. so pat rinee dinombre hathe .3. nombres to be brought forthe in lyyn. But rolids. nombre may be hade twies in nombre, for other it is hale in hym4 selfe, oper in a-noper. If a nombre be hade twies in hym-self, ope. ones in lis qualrat, pat is the same, pat a culjike ${ }^{1}$ is, And is the culnicumsame that is solide. And yf a nombre twies he hade in a-noper, the nombre is elepede solide and not cubike, as twies .3, and pat .2.

8 makithe.12. Wherfor it is opyne that alle cubite nombre is solicle, all cubics and not conuertide. Cubike is pat nombre pat comythe of ledynge are soluters. of hym-selfe twyes, or ones in his quadrat. And here-by it is open that o nombre is the ronte of a quarlrat and of a cubike. Natleles

12 the same nombre is not qualrat and cubike. Opyne it is also that sonumber alle nombres may be a rote to a quadrat and cubike, but not alle minear bend nombre quadrat or euhike. Therfor sithen pe ledynge of vnyte in hym-self ones or twies nonglit cometle but vnytes, Seithe Boice in 16 Arsemetrike, that vingte potentially is al nombre, and none in act. linity is not And vndirstonde wele also that betwix euery .2. qualuates ther is a

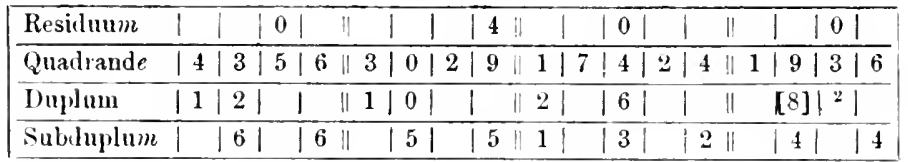

meene proporcionalle, That is openele thus; lede the rote of o quadrat into the rote of the oper quadrat, and pan wolle pe meene 20 shew. Also betwix the next .2. cubikis, me may fynde a clouble a note on meene, that is to sey a more mean proporthus, as to brynge the rote of the lesse into a quadrat of the more. The lesse thus, If the rote of the more be brought Into the quadrat 24 of the lesse.

${ }^{3}$ To draw a rote of the nombre (fualrat it is What-ener nombre be Lroposede to fynde his rote and to se yf it be quadrat. And to fima $y f$ it be not quadrat the rote of the most quadrat fynde out, vinder equare rout.

28 the nombre proposede. Therfor $y$ f thow wilt the rote of any quadrat nombre draw out, write the nombre by bis differences, and compt the nombre of the figures, and wete $\mathrm{yf}$ it he odle or even. And $\mathrm{yf}$ it be even, than most thow begynne worche vinter the last save one. legin with 32 And yf it be ode with the last; and forto sey it shortly, al-weyes place. fro the last ode me shalle begymne. Therfor vnder the last in an od place sette, me most fynde a digit, the whiche lade in hym-selfe it puttithe away that, pat is oner lis hede, oper as neighe as ne

$$
27 \text { in MS. } \quad 3 \text { runs on in MS. }
$$


Find the liearest square root square root
of that num of that nuni.

double it,

1 Fol. $5 \$ b$. and set the double one the right.

Find the second fignre by division.

Multiply the double by the second figure, it the square it the square
of lihe second figure, and subtract.

Examples. may: suche a digit fonnle and withliaw fro his overer, me most donlle that digit and sette the clouble vnder the next figure towarle the-right honde, and his vuler double vuler hym. That clone, than me most fynde a-noper digit vnder the next figmre l,ifore the cloubjerle, the whiche 'brought in clomble settethe a-way alle that is oner his herle as to rewarle of the cloublede: Than brought into hym-self settithe all away in respect of hym-self, Other do it as nye as it may be do: other me may with-ulraw the digit 2 [last] founcle, anıl lede hym in clouble or donble hym, and after in hym-selfe; Than loyne to-geder the produccione of them bothe, So that the first figure of the last product be adicile before the first of the first productes, the seconde of the first, elc. and so forthe, subtralie fro the totalle 12 nombre in respect of pe digit. Ancl if it hap pat no cligit may be

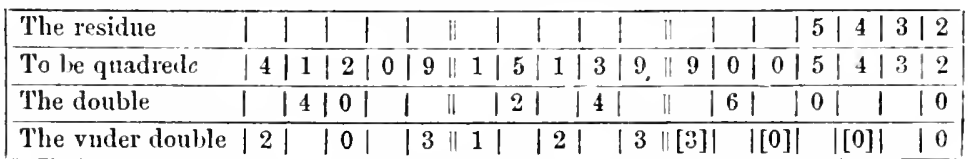

foumcle, Than sette a cifre vnclre a cifre, and cesse not tille thow fyncle a digit; and whan thow hast foumle it to double it, neper to special cases. sette the doublede forwarle nether the vucler doublede, Till thow fynde vndre the first figure a dirit, the whiche lade in alle cloulle, settyng away alle that is ouer hym in respect of the doublede: Than lede hym into hym-selfe, and put a-way alle in regarde of hym, other The residue. as nyghe as thow maist. That done, other onght or nought wolle

be the residue. If nought, than it shewithe that a nombre comlponede was the quadrat, and his rote a digit last founde with vndere-double other vndirdoubles, so that it be sette be-fore: And yf ought ${ }^{3}$ remayne, that shewith that the nombre proposede was not 24 quadrat," but a digit [last found with the subluple or subduples

This lable ls consiructed for use in cube root sums, giving the value of ab. ${ }^{2}$

\begin{tabular}{|c|c|c|c|c|c|c|c|c|}
\hline 1 & 21 & 3 & 41 & 5 & 6 & 7 & & 9 \\
\hline 2 & 81 & 12 & $16 !$ & 20 & 24 & 281 & 32 & 36 \\
\hline 3 & $|18|$ & 271 & 361 & 45 & 54 & 631 & 721 & 81 \\
\hline 4 & $|32|$ & 48 & 64 & 80 & 96 & $112^{5}$ & 128 & 144 \\
\hline 5 & 50 & 751 & 100 & 125 & 150 & 175 & 200 & 225 \\
\hline 6 & 172 & 108 & 144 & 180 & 216 & 2521 & 2881 & $\longdiv { 3 2 4 }$ \\
\hline 7 & $98 \mid$ & 147 & 196 & 245 & 294 & $343 \mid$ & 393 & $\mid 441$ \\
\hline 8 & $|128|$ & 1921 & 256 & 320 & 384 & 4481 & 512 & 1556 \\
\hline 9 & 168 & 243 & 324 & 405 & 1486 & $5 \delta \bar{\tau}$ & 648 & $1729^{\circ}$ \\
\hline
\end{tabular}

$$
2 \text { 'so' in MS. } 3 \text { 'nought' in MS. }
$$

"MS. adds here: 'wher-vpone se the table in the next side of the next leefe.' 5110 in MS. 6 in MS. 
is] The rute of the most inuidrat conteynete vinlre the nombre proposele. Therfor yf thow wilt prove yf thow have wele do or How to prove no, Multiplie the digit last founde with the vnder-ionble oper voder- root withent 4 loublis, and thow shalt fynde the same figures that thow haddest remainder.

before; And so that nought be the 'resilue. And yf thow have ' Fol. 5s. any resilue, than with the addicioun perof that is resernede with-out in thy table, thow shalt fynde thi first figures as thow liandest them 8 before, etc.

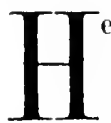

ecre folowithe the extraccioun of rotis in cullike nombres; nefinition wher-for me most se what is a nonl,re culike, and what number and is his roote, Anl what is the extraccionn of a rote. $A$

12 nombre cubike it is, as it is before leclarele, that comethe of lelyng of any nombre twies in hym-selfe, other ones in his quadrat. The rote of a nombre culjike is the nombre that is twies lade in hym-selfe, or ones in his quadrat. Wher-thurgle it is open, that 16 cuery nombre quadrat or cubike have the same rote, as it is seile before. And forto draw out the rote of a cubikn, It is first to fynde pe nombe proposede $\mathrm{yf}$ it be a cubike; Aml yf it be not, than thow most make extraccioun of his rote of the most culike 20 rndre the nombre proposide his rote fummle. Therfor jmoserle some nombre, whos cubical rote pou woldest draw out; First thow Mank of most compt the figures by fourthes, that is to sey in the place of lirees. thousanles; Ind vnder the last thousande liace, thow most fynde Find the first 24 a digit, the whiche lade in hym-self cubikly puttithe a-way that pat is ouer his hele as in respect of hym, other as nyghe as thow maist. That done, thow most trebille the digit, and that triplat treble it and

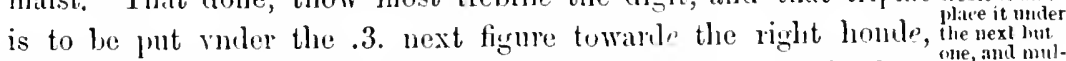

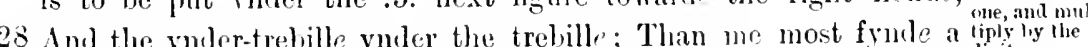
And the ruse digit. dirit vulre the next figure bifore the triplat, the whiche with his Then fint the

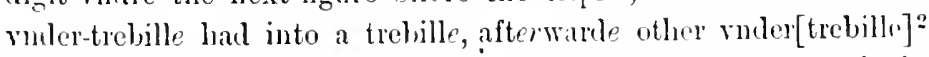
had in his froduccionn, puttethe a-way alle that is oner it in 32 regamle of ${ }^{3}$ [the triphat. Then lade in hymself puttithe away that pat is over lis herle as in respect of hym, other as nyoge as thou maist:] That done, thow most trebille the digit ayene, and the Multint the triplat is to be sette rmiler the next .3. figure as hefore, Anl and hlie set36 the vmler-trebille vmler the trebille: and than most thow sette ond dice by this forwarle the first triplat with his vodre-trebille hy .2. differences. And than most thow fynde a digit vuder the next figure before the triplat, the whiche withe his ruler-triplat himl in his triplat after. 
subtract. warde, other vnder-treblis lat in product ${ }^{1}$ It sittethe a-way at that 1 Fol. $55 b$. is oner his hede in respect of the triplat than had in liym-self cubikly, ${ }^{2}$ or as nyghe as ye may.

Examples.

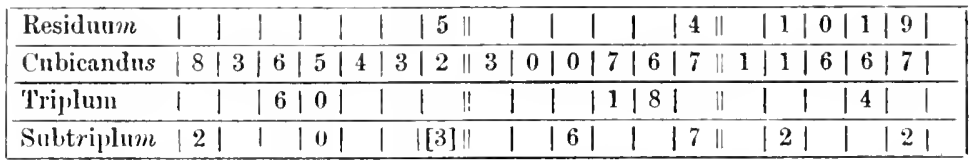

Continue this process iill the first tigure is reiched.

Fixamples.

The residue. founde. ${ }^{5}$ That done ought or nought most be the residue. If it be nought, It is open that the nombre proposecle was a cubike nombre, And lis rote a digit fommle last with the vnder-triples: If the rote therof wex bade in hym-selfe, and afterwarle proluct they shalle make the first figures. And yf ought be in resillue, kepe that without in the table; and it is opene that the nombre was not a cubike. lont a digit last foumle with the vndirtriplis is rote of the most cubike vulce the nombre proposede conteynede, the special cases. whiche rote $\mathrm{yf}$ it be hade in hym-selfe, And afterwarde in a prouluct of that shalle growe the most cubike vudre the nombre proposede conteynede, And yf that be addede to a cubike the residue reseruede - Fol. 56. in the table, wolle make the same figures that ye hade first. ${ }^{6}$ And

2 MS. adds here : 'it settetlie a-way alle his respect.'

3 'aucterioracioun' in MS.

4 MS. adds here: "with an vndre-triple / other of an vndre-triple in a triple or triplat is And after-warde with ont vndre-triple other vndre-triplis in the proluct and ayene that product that cometh $c$ of the ledyng $c$ of a digit found $c$ in hym-self $c$ cubicall $c$ '।

5 MS. adds here: 'as ther had be a divisionn made as it is opened $c$ before.' 
yf no digit after the anterioracioun ${ }^{1}$ may not be founde, than put there a cifre vndre a eifre yndir the thirde figure, And put forwarle special care. pe figures. Note also wele that yf in the nombre proposete ther 4 ben no place of thowsandes, me most begynne vnder the first figure in the extraccioun of the rote. some vsen forto listingue the nombre ly threes, and ay begynne forto wirche rndre the first of

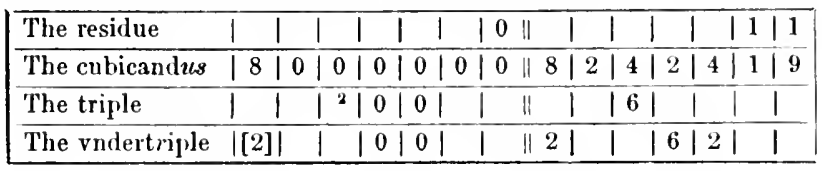

Examples.

the last ternary other uncomplete nombre, the whiche maner of 8 operacioun accordethe with that before. And this at this tyme suffisethe in extraccioun of nombres quadrat or culbikes etc.

$\begin{array}{lllllll}1 & 2 & 3 & 4 & 5 & 6 & \text { A table of }\end{array}$ one. $\mathrm{x}$. an. hundrele / a thowsande / $\mathrm{x}$. thowsande / An hundrede numbers; 7 thowsande / A thowsande tymes a thowsande / $\mathrm{x}$. thousande tymes from the

12 a thousinde / An hundrede thousande tymes a thousande $\mathrm{A}$ thousande thousande tymes a thousande / this is the $\mathrm{x}$ place etc.

$$
\text { [Encle.] }
$$
1 MS. anteriocacioun.
24 in MS. 


\section{Actomptunige by counters.}

${ }^{1} 116$ b. 1 The seconde dialoge of accomptynge by counters. Matyster:

TOwe that you have learned the commen kyndes of Arithmetyke with the penne, you shall se the same art in counters:

1 whiche feate doth not only serue for them that can not write 4 and rede, but also for them that can do bothe, but have not at some tymes theyr penne or tables relye with them. This sorte is in two fourmes commenly. The one by lynes, and the other withont lynes: in that $y^{t}$ hath lynes, the lynes do stande for the order of places: 8 and in $y^{t}$ that hath no lynes, there must be sette in theyr stede so many counters as shall nocle, for eehe lyne one, and they shall supplye the stede of the lynes. S. By examples I shuld better

2117 a perceane your meanynge. Mr. For example of the ly2nes: Lo here 12 you se vi. lynes whiche stande for syxe places so $=$ that the nethermost standeth for $y^{\mathrm{e}}$ fyrst place, and
the next abone it, for the sccond : and so vpward tyll you come to the hyghest, which is the syxte lyne, and standeth for 16 the syxte place. Now what is the valewe of euery place or lyne, Numeration. you may percenue by the figures whiche I haue set on them, which is accordynge as you learned hefore in the Numeration of figures ly the pemne : for the fyrste place is the place of vnitics or ones, and 20 enery counter set in that lyne betokeneth but one: and the seconde lyne is the place of 10 , for enery counter there, standeth for 10 . The thyrd lyne the place of hundredes: the fourth of thousandes: and so forth. S. Syr I do perceaue that the same order is here of 24

${ }^{3} 117$ b. lynes, as was in the other figures ${ }^{3}$ by places, so that you shall not nede longer to stande about Numeration, excepte there be any other difference. MI. If you do vnilerstancle it, then how wyll you set $1543 ?$ S. Thus, as I suppose. $\#$. Youl liaue set $\mathrm{y}^{\mathrm{e}} 28$ places truely, but your figures be 
for the metest figure in this behalfe, is the figure of a counter round, as $y$ ou se here, where I haue expressel that same summe. $S$. So that you late not one figure for 2 ,

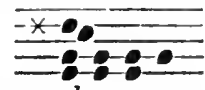
4 nor 3 , nor 4 , and so forth, but as many digettes as you haue, you set in the lowest lyne: and for euery 10 you set one in the second line: and so of other. But I know not by what reason you set that one counter for 500 betwene two lynes. $\boldsymbol{M}$. you shall re8 member this, that when so ener you nete to set lowne 5, 50, or 500 , or 5000 , or so forth any other nomber, whose numerator ' is 5 , you shall set one counter for it, in the next sprace aboue the lyne that it hath his clenomination of, as in this example of that 500 , 12 byeause the mumerator is 5 , it must be set in a royd space: and bycause the clenominator is humeled, I knowe that his place is the royde space next aboue hundredes, that is to say, aboue the thyrd lyne. And farther you shall marke, that in all workynge by this 16 sorte, yf you shall sette downe any summe betwene 4 and 10 , for the fyrste parte of that nomber you shall set lowne 5 , \& then so many counters more, as there reste nombers aboue 5. And this is true bothe of digettes and articles. And for example I wyll set 20 downe this summe 287965 , marke well, you nede none lerne the numeration of

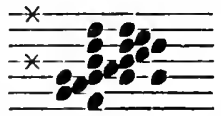
which summe yf you other examples for to 2 this forme. But this 21186. shal you marke, that as you dyd in the other kynde of arithmetike, 24 set a pricke in the places of thousanles, in this worke you shall sette a starre, as you se here. $S$. Then I perceave numeration, but I praye you, howe shall $I$ do in this arte to adde two summes or Additlon. more together? $\boldsymbol{M} \boldsymbol{I}$. 'The easyest way in this arte is, to adde but 2 28 summes at ones together: how be it you may adle more, as I wyll tell you anone. Therfore when you wyll adde two summes, you shall fyrst set downe one of them, it forseth not whiche, concl then by it drawe a lyne crosse the other lynes. And afterward 32 set downe the other summe, so that that lyne may be betwene them, as yf you wolde adde 2659 to 8342 , you must set your summes as you se here. And then yf you lyst, you ${ }^{3}$ may alde the one to the other $3119 u$. 36 in the same place, or els you may adde them both together in a newe place: which waye, bycause it is moste playnest, I wyll showe you fyrst. Therfore wyl I begymne at the vnites, whiche in the fyrst summe is but 2, and in $y^{\prime \prime}$ second summe 9, that maketh 11 , 40 those do I take vp, and for them I set 11 in the new roume, thus, 


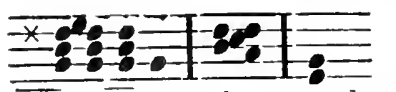

Then do I take vp all $y^{e}$ articles rnder a hundred, which in the fyrst summe are 40 , and in the second summe 50, that maketh 90 : or you may saye better, that in the fyrste summe there are 4 articles of 10 , and 4 in the seconde summe 5 , which make 9 , but then take helle that

1196 . you sette them in theyr ryght lynes as you se here. Where I

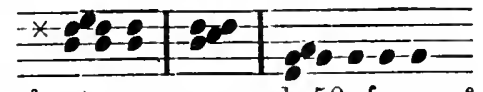
liaue taken awaye 40 from the fyrste summe, and 50 from $y^{\mathbf{e}} 8$ second, and in theyr stede I haue set 90 in the thyrle, whiche I haue set playnely $\mathrm{y}^{\mathrm{t}}$ you myght well perceaue it: how be it seynge that 90 with the 10 that was in $y^{\mathrm{e}}$ thyrd romme all relly, doth make 100 , I myghte better for those 6 comnters set 1 in the thyrle 1 ? lyne, thus: $=$ For it is all one summe as you may se, but it is beste, $=$ neuer to set 5 counters in any line, for that may be done with 1 counter in a lygher place. $S$. I iulge that good reason, for many are vnnedefull, where one wyll serue. 16

2120a. $M$. Well, then ${ }^{2}$ wyll I adde forth of humilredes: I fyule 3 in the fyrste summe, and 6 in the seconde, whiche make 900 , them do I take vp and set in the thyrt roume where is one hundred all relly, to whiche I put 900 , and it wyll be 1000 , therfore I set one 20 counter in the fourth lyne for them all, as you se here. Then alde I $y^{\mathbf{e}}$ thousandes together, whiche in the fyrst summe are 8000 , and in $\overline{y^{\mathrm{e}}}$ second 2000, that maketl 10000: them do I take vp from those 24 two places, and for them I set one counter in the fyfte lyne, and then appereth as - - you se, to be 11001 , for so many loth ${ }^{3} 120 \mathrm{~b}$. amount of the $=$ addition of 8342 to $2659 .{ }^{3} \mathrm{~S}$. Syr, this I do pereeave: but how shall I set one summe to an other, not 28 chaungynge them to a thyrde place? M. Marke well how I do it: I wyll alde together 65436 , and 3245 , whiche fyrste I set downe thus. Then do I begynne with the smalest, which

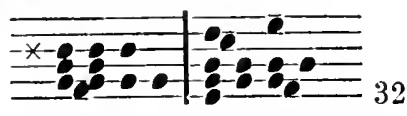
in the fyrst summe is , that do I take vp, and wold put to the other 5 in the seconcle summe, sanyuge that two counters can not be set in a voyd place of 5 , bnt for them bothe I must set 1 in the seconcle lyne, which is the place of 10 , tlerfore I take vp the 5 of 36 the fyrst summie, and the 5 of the seeonde, and for them I set 1

" 121 $a$. in the second lyne, ${ }^{4}$ as you se here. Then do I lyke wayes take vp the 4 counters of the fyrste summe and

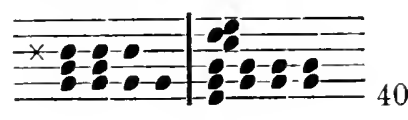


seconde lyne (which make 40) and adde them to the 4 counters of the same lyne, in the sceond summe, and it maketh 80 , liut as 1 sayde I maye not conueniently set aboue 4 counters in one lyne, 4 therfore to those 4 that I toke vp in the fyrst summe, I take one also of the seconde summe, and then haue I taken vp 50 , for whiche 5 counters I sette downe one in the space ouer $y^{e}$ second lyne, as here loth appere. 8 as well $w^{\text {t }}$ those hat set downe $\mathrm{y}^{\mathrm{e}}$

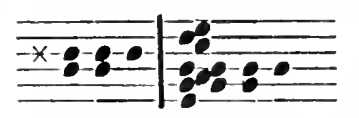
${ }^{1}$ and then is there 80 , 4 counters, as $\mathrm{yf} \mathrm{I}$ other 4 also. Now do I take the $200 \mathrm{in}$ the fyrste summe, and adde them to the 400 in the seconde summe, and it maketh 600 , therfore I take vp the 2 12 counters in the fyrste summe, and 3 of them in the seconde summe, and for them $5 \mathrm{I}$ set 1 in $y^{\mathrm{e}}$ space aboue, thus. Then I take $y^{e} 3000$ in $y^{e}$ fyrste summe, vnto whiche there are none in the

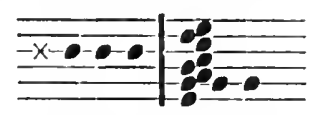

16 second summe agreynge, therfore I do onely remone those 3 counters from the fyrste summe into the secomle, as here doth appere.

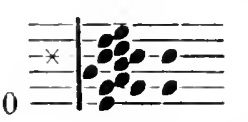
'And so you see the hole summe, that amounteth of the addytion of 65436 with 3245 to be $6868[1]$. Aud yf you haue marked these two examples well, you nede no farther enstruction in Addition of 2 only summes: but yf you have more then two summes to adle, you nay alde them thus. Fyrst adde two of them, and then adde the thyrde, 24 and $y^{\mathrm{e}}$ fourth, or more $\mathrm{yf}$ there be so many: as $\mathrm{y}^{\mathrm{f}} \mathrm{I}$ wolde arlde 2679 with 4286 and 1391. Fyrste I adde the two fyrstc summes thus. $*-20-{ }^{3}$ And then I adde the 3 19:- 8.

$2 S$ And so of more yf you have them. S. Nowe I thynke

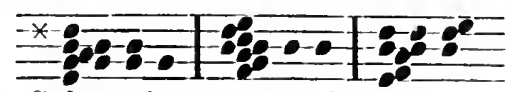
beste that you passe forth to Subtraction, execpt there be any wayes to examyn this maner of Aldition, then I thynke that were 32 good to be knowen nexte. $M I$. There is the same profe here that is in the other Adlition by the penne, I meane Subtraction, for that subtration. onely is a sure waye: but consyderynge that Subtraction must be fyrste knowen, I wyl fyrste teache you the arte of Sultraction, and 36 that by this example: I wolde subtracte 2892 out of 8746 . These summes must I set downe as I lyal in Addition: but here it is best to set the lesser nomber fyrste, thus. Then shall I begynne to sub-

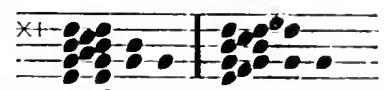
$116 a(210)$ 40 tracte the greatest nombres fyrste (contrary to the rse of the penne) 


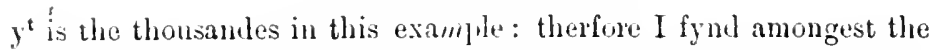
thousandes 2, fur which I withlrawe so many from the seconde summe (where are 8 ) and so remayneth there 6 , as this example showeth. Then do I lyke wiyes with the hun- = Uredes, of whiche in the

$110 b$. fyrste summe II fyncle 8 , and is the seconde summe but 7 , out of whiche I ean not take 8 , therfore thus muste I lo: I muste loke how moche my summe dyffereth from 10, whiche I fymle here to 8 be 2, then must I bate for my summe of 800 , one thousamle, and set lowne the excesse of hundredes, that is to saye 2 , for so mache $100[0]$ is more then I shuld take v1. Therfore from the fyrste summe I take that 800 , and from the second summe where are 12 6000, I take vp one thousande, anl leue 5000; but then set I lowne the 200 unto the $700 \mathrm{y}^{\mathrm{t}}$ are there all realye, and make them 900 thus. =+ Then come I to the artites of temnes = where in the fyrste summe 16

2air. I fyule 90, and in the seconde summe but only 40 : Now consyileryng that 90 can not be bated from 40, I loke how moche $y^{t} 90$ doth dyfler frum the next smmme alone it, that is 100 (10 elles whiche is all to one effecte, I loke how moch 9 doth dytter 20 from 10) arrl I fynd it to be 1 , then in the stede of that 90 , I do take from the second summe 100: but consyderynge that it is 10 to moche, I stt downe 1 in $y^{e}$ nrxte lyne beneth for it, as yon se here. Sauynge that here $=$ I haue set one 24 counter in $y^{\mathrm{e}}$ space in stede $=$ of 5 in $\mathrm{y}^{\mathrm{e}}$ nexte lyne. And thus have 1 subtricted all sane two, which I must bate from the 6 in the secont summe, and there wyll remayne 4 , thus.

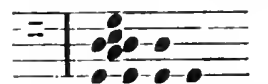
So $y^{\mathrm{t}}$ yf I subtracte 2892 from 8746 , the re- 28 mayner wyll be $5854,{ }^{3} \mathrm{An} \cdot \mathrm{l}$ that this is truely wought, gou maye june ly Ahlition: for yf gou adle to this remayner the same sumne that fou dyal snbtracte, then wyll the formar summe 5746 amomit aginne. $S$. That wyll I poue: and 32 fyrst I set the summe that was subtricted, which was 2892 , amol then the remayner iset, thus. Then do 1 inlite fyrst $y^{* 2}$ to $t$, whiche

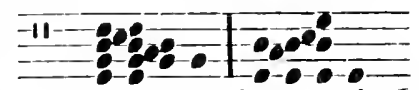
maketh 6 , su take $l v 1,5$ of those counters, and in theyr stecte I 36 settr 1 in the spate, as liere appereth. "Then ilo I alde the 90 nexte abone to

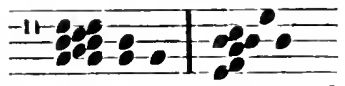
ilw 50 , and it maketh 140 , therfore $I$ talie v 1 those 6 comters, and for them 1 sotte 1 to the humbedes in $y^{e}$ thyrde lyne, and 4 in $y^{e}$ to 
second lyne, thus. the humdredes, of

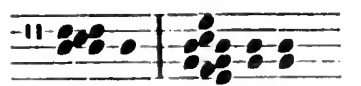

Then do I come to whiche I fymle 8 in the fyrst summe, and 9 in $y^{\mathrm{e}}$ second, that maketh 1700 , therfore I 4 take v' those 9 counters, and in they stede 1 sette 1 in the .iii. lyne, and 1 in the space nexte beneth, and 2 in the thyrde lyno, as you se here. fyrste summe Then is there lefte in the 8 shall take r from summe, to $y^{\mathrm{e}}$ one $y^{\mathrm{t}}$ is there all reily: rmal then wyll the hole summe appre (ats you may wel se) to be 8746 , which was $y^{n}$ fyrst grosse summe, aml therfore

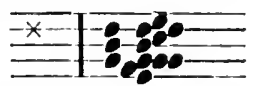
121 do pereeaue, that I hadde well subtracted before. And thus yon may se how Subtration maye be tryed ly Adlition. S. I perceaue the same order here $w^{t}$ counters, $y^{t}$ I lerned beiore in figures. $M$. Then let me se howe can you trye Addition by 16 Subtraction. S. Fyrste I wyl set forth this example of Addition where I have added 2189 to 4988 , and the hole summe appereth to be $i 1 \pi \mathrm{i}$, whether that

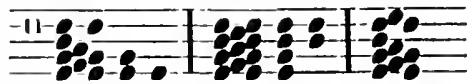
2 Nowe to trye summe be well

20 adiled or no, I wyll subtract one of the fyrst two summes from the thyrs, and if I haue well done $y^{\mathrm{e}}$ remayner wyll be lyke that other summe. As for example: I wyll sulbtacte the fyrste summe from the thyrde, whiehe I set thins

24 in theyr order. Then to I subtract 2000

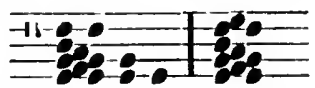
of the fyrste summe from $y^{\mathrm{e}}$ second summe, and then remayneth there 5000 thus. $-\overline{-*}$ Then in the thyrd lyne, I subtract $y^{\mathbf{e}} 100$

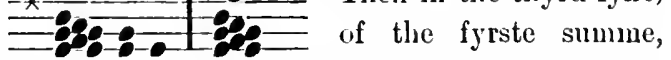

28 from the second summe, where is onely 100 also, and then in $y^{e}$ thyrde lyne resteth nothyng. Then in the second lyne with his space oner hym, I fynde 80 , which I shuld subtract ${ }^{3}$ from the other summe, then seyner there are but only 70 I must take it out 32 of some liysher summe, which is here only 5000, therfore I take v1 5000 , and seyng that it is to moch by 4920 , I sette downe so many in the seconde ronme, whiche with the 70 beynge there all redy do make 4990, \& then the summes

36 cloth stande thus. Tet remayneth there

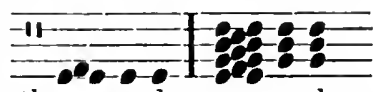
in the fyrst summe 9, to be bated from the second summe, where in that place of vuities dothe appere only $\tau$, then I muste bate a hygher summe, that is to saye 10 , but seynge that 10 is more then 409 (which I sluulde abate) by l, therfore shall I take vp oue counter from the seconde lyne, and set downe the same in the fyrst ${ }^{4}$ or

s $119 b$.

$120 a$. 
lowest lyne, as you se here. ented this worke, and the

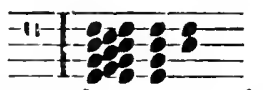
And so haue I to be $\mathrm{y}^{\mathrm{e}}$ same, whiche was $\mathrm{y}^{\mathrm{e}}$ seconde summe of my aldition, and therfore I perceaue, I hane wel done. $M$. To stande longer about this, it is but folye: excepte that this you maye also vnderstande, that many do begynne to sultracte with eounters, not at the lygghest summe, as I have taught you, but at the nethermoste, as they do vse to adde: and when the summo to be abityd, in any lyne appeareth greater then the other, then do they borowe one of the next hygher roume, as for example: yf they shuld abate 1846 from 2378 , they set $y^{\mathrm{e}}$ summes thus.

$11206 .:-1$ And fyrste they take 6 whiche is in the

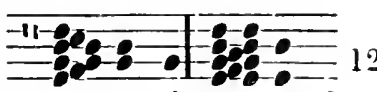
lower lyne, and his space from 8 in the same roumes, in $y^{\mathrm{e}}$ second summe, and yet there remayneth 2 counters in the lowest lyne. Then in the second lyne must 4 be subtracte from $i$, and so remayneth there 3 . Then 8 in the thyrde lyne and his space, from 16 3 of the second summe can not he, therfore do they bate it from a hygher roume, that is, from 1000 , and hyeause that 1000 is to moch by 200 , therfore nust I sette downe 200 in the thyrde lyne, after I have taken $\mathrm{rl}, 1000 \mathrm{from}$ the fourth lyne: then is there yet 20 1000 in the fouth lyne of the fyrst summe, whiche $y$ I I withdrawe from the seconde summe, then doth all $y^{\mathrm{e}}$ figures stande in this order. So that (as you se) it differeth not greatly whether

$2121 a$. Multiplica. tiun.

$\$ 1212$. at ${ }^{2}$ the lower. How he it, as some menne lyke the one waye beste, so some lyke the ather: therfore you now knowyng bothe, may vse whiche you lyst. But nowe tonchynge Multiplication: you shall set your nombers in two rounes, as you dyd in those two other 28 kymles, but so that the multiplier be set in the fyrste roume. 'Then shall you besyn with the hyghest nombers of $y^{e}$ seconde roume, and multiply them fyrst after this sort. Take that ouermost lyne in your fyrst workynge, as yf it were the lowest lyne, 32 setting on it some mouable marke, as you lyste, and loke how many counters be in hym, take them vp, and for them set downe the hole multyplyer, so many tymes as you toke rp counters, reckenyng, I saye that lyne for the vnites: and when you haue so 36 done with the liygheest nomber then come to the nexte lyne

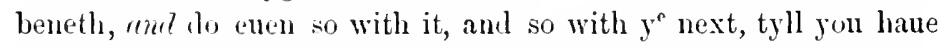
done all. And of there be any nomber in a space, then for it ${ }^{3}$ shall you take $\mathrm{y}^{\mathrm{e}}$ multiplyer 5 tymes, and then must you recken 40 that lyne for the vnites whiche is nexte beneth that space: or els 
after a shorter way, you shall take only halfe the multyplyer, but then shall you take the lyne nexte aboue that space, for the lyne of vnites: but in suehe workynge, yf chanuee your multyplyer be an 4 oulde nomber, so that you can not take the halfe of it iustly, then muste you take the greater halfe, and set downe that, as if that it were the iuste halfe, and farther you shall set one counter in the space beneth that line, which you recken for the lyne of vuities, or 8 els only remone forward the same that is to be multyplyed. $S$. Yf you set forth an example hereto I thynke I shal perceane you. M. Take this example: I wold multiply 1542 by 365 , therfore I set $y^{\mathrm{e}}$ nombers thus. 12 gymlne at the 1000 in

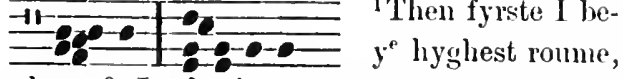
as $y$ it were $y^{\mathrm{e}}$ fyrst place, \& I take it vp, settynge lowne for it so often (that is ones) the multyplyer, which is 365 , thus, as you se here: $=$ 16 counter taken $-\frac{-*-0-0}{0}=0$ fourth lyne, I = lave sette downe other 6 , whiche make $y^{\mathbf{e}}$ summe of the multyplyer, reckenynge that fourth lyne, as $y$ it were the fyrste: whiche thyng I haue marked $20 \mathrm{by}$ the hand set at the begynnyng of $y^{\mathbf{e}}$ same, S. I pereeaue this well : for in dede, this summe that you haue set lowne is 365000 , for so moche doth amount ${ }^{2}$ of 1000 , multiplyed by 365 . M. Well then to go forth, in the nexte space I fynde one counter which I 24 remone forwarl but take not vp, but do (as in sueh case I must) set downe the greater laalfe of my multiplier (seyng it is an olde nomber) which is 182 , amel here I do styll let that fourth place stanel, as $y f$ it were $y^{\mathrm{e}}$

$28 \mathrm{fyrst}:$ as in this fourme you se, where I haue set

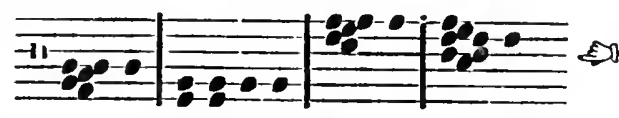
this multiplycation with $y^{\mathrm{e}}$ other: but for the ease of your vuderstandynge, I haue set a lytell lyne betwene them : now shulde they 32 both in one summe stand thus.

${ }^{3}$ Howe be it an other fourme to multyplye suche counters

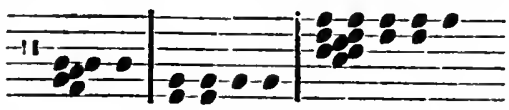

in space is this: Fyrst to remoue the fynger to the Iyne nexte 36 benethe $y^{e}$ space, roml then to take rl $y^{e}$ comnter, and to set downe $y^{e}$ multiplyer .v. tymes, as here you se. Which summes yf you do

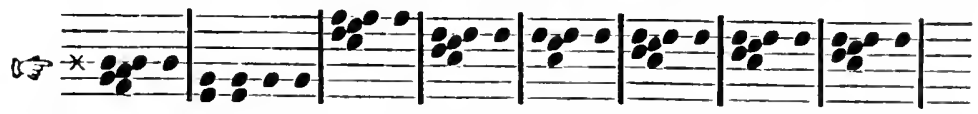
adde together into one summe, you shal perceatue that it wyll be $\mathrm{y}^{\mathrm{e}}$ 
$1123 \mathrm{~b}$. same $\mathrm{y}^{\mathrm{t}}$ appeareth of $\mathrm{y}^{\mathrm{e}}$ other working before, so that 'bothe sortes are to one entent, but as the other is much shorter, so this is playner to reason, for suche as haue had small exercyse in this arte. Not withstandynge you maye adde tlem in your myde before you sette them downe, as in this example, you myghte hame sayde 5 tymes 300 is 1500, aml 5 tymes 60 is 300 , also 5 tymes 5 is 25 , whiche all put together do make 1825, which you maye at one tyme set downe yf you lyste. Sut nowe to go forth, I must remone the liand to the nexte counters, whiche are in the second lyne, and there must I take v' those 4 counters, settynge downe for them my multiplyer 4 tymes, whiche thynge other I maye do at 4 tymes seuerally, or elles I may gather that hole summe in my 12 mynde fyrste, and then set it lowne: as to saye 4 tymes 300 is $1200: 4$ tymes 60 are 240 : and 4 tymes 5 make $20: y^{\text {t }}$ is in all $1460, y^{\mathrm{t}}$ shall I set lowne also : as here you

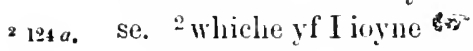

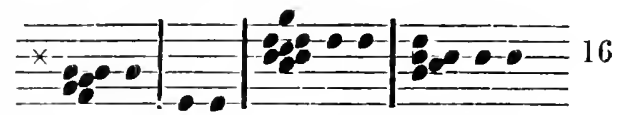
in one summe with the formar nombers, it wyll appeare thus.

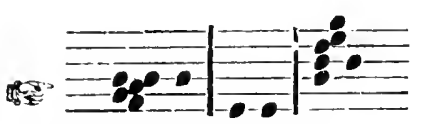
Then to ende this multiplycation, I remoue the fynger to the lowest lyne, 20 where are onely 2, them do I take vp, and in theyr stede do I set downe twyse 365, that is 730 , for which I set ${ }^{3}$ one in the space aboue the thyrd lyne for 500 , and 2 more in the thysl lyne with that one that is there all reslye, and 24 the reste in theyr order, and so have I ended the hole summe thus.

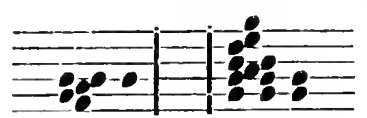
Wherly you se, that 1542 (which is the nomber of yeares syth Ch[r]ystes incarnation) lnẹng multyplyed by 36528 which is the nomber of dayes in one yeare) dothe amounte rnto 562830 , which dechareth $y^{\mathrm{e}}$ nomber of daies sith Chrystes incarnation into the ende of $1542^{4}$ yeares. (besyde 385 dayes and 12 houres for lepe yeares). S. Now wyll I joue hy an other example, 32 as this : 40 labourers (after 61. $y^{\text {e }}$ day for eche man) haue wrought

5 195a. 28 dayes, I wold "know what theyp wages doth amount vinto: In this case muste I worke doublely: fyrst I must multyplye the - nomber of the labourers hy ye wages of a man for one clay, so wyll 36 $y^{\mathrm{e}}$ charge of one daye amount: then secondarely shall I multyply that charge of we daye, by the hole nomber of dayes, and so wyll the hole summe appeare: fyrst therefore I shall set the summes thus.

\footnotetext{
+1342 in original.
} 
Where in the fyrste space is the multyplyer the second space is set the nomber of the worke men to be multy4 plyed : then saye I, 6 tymes 4 (reckenynge that second lyne as the lyne of vnites) maketh 24 , for whiche summe I shulde set 2 comnters in the thyrde lyne, and $t$ in the seconde, therfore do I set 2 in the thyrie lyne, and let the 4 stand styll in the seconde 8 lyne, thus. $=$ So apwereth the hole dayes wages to be 240\%. agayn the same summe by the nomber of dayes and fyrste I sette the nombers, thus. $=$ Then bycause there

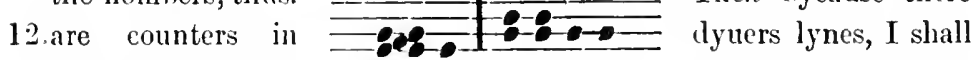
begynne with the hyghest, and take them vp, settynge for them the multyplyer so many tymes, as. I toke vp counters, $y^{t}$ is twyse, then wyll $\mathrm{y}^{\mathrm{e}}$ summe stande thus. $16 \mathrm{I}$ to $\mathrm{y}^{\mathrm{e}}$ seconde lyne, and take counters, settynge for them the multiplyer foure tymes, so wyll the hole summe appeare thus. ${ }^{2}=-\mathrm{f}=$ So is the hole wages of 40 workemen, for 28 三 dayes (after 6u. eche 20 daye for a man) 6720k. that is 560 s. or 28 li. $M$. Now if you wold prone Multiplycation, the surest way is by Dyuision : therfore Diuision. wyll I viler passe it tyll I haue tauglit you $y^{\mathrm{e}}$ arte of Dinision, whiche you shall worke thus. Fyrste sette downe the Diuisor for

24 feare of forgettynge, and then set the nomber that shalbe deuided, at $y^{e}$ ryghte syde, so farre from the diuisor, that the quotient may be set betwene them: as for example: Yf 225 shepe cost 45 l'i. what dyd enery shepe cost? To knowe this, I shnlde diuide the 28 hole summe, that is 45 l'i. by 225 , lut that ean not be, therfore must I fyrste reduec that 45 l'i. into a lesser denomination, as into shyllynges: then I multiply 45 by 20 , and it is 900 , that summe shall I diuide ly the nomber of ${ }^{3}$ shepe, whiche is 225 , these

32 two nombers therfore I sette thus. Then begrmme I at the hyghest lyne

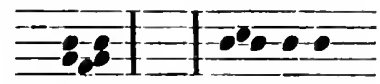
of the diuident, and seke how often I may have the diuisor therin, and that maye $I$ do 4 tymes, then say I, 4 tymes 2 are 8 , whyche yf 36 I take from 9 , there resteth but 1 , thins And bycanse I founde the diuisor 4 tymes in the diuidente, I hame set-(as your se) 4 in the mydlle romme, which ${ }^{4}$ is the place of the quotient: but now must I take $s 126 b$. 40 the reste of the diuisor as often out of the remayner: therfore come 
I to the seconde lyne of the dinisor, sayeng 2 foure tymes make 8 , take 8 from 10 , and there resteth 2 , thus. Then come I to the lowest

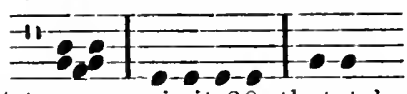
nomber, which is 5 , and multyply it 4 tymes, so is it 20 , that take I from 20, and there remaynetl nothynge, so that I se my quotient to be 4 , whiche are in valewe shyllynges, for so was the diuident: and therby I knowe, that yf 225 shepe dyd coste 15 l'i. enery shepe coste $4 \mathrm{~s}$. $S$. This can I do, as you shall perceaue by this example: Yf 160 sowlilyars do spende enery moneth 68 l'i. what spendeth

1127b. eche man? Fyrst ${ }^{1}$ bycause I can not diuide the 68 by 160 , therfore I wyll turne the poumles into pennes by multiplicacion, so shall there be 16320 d'. Nowe muste I dinicle this summe by the.12 nomber of sowldyars, therfore I set them in order, thus. Then begyn $\mathrm{I}$ at the hyghest place of the dinidente, sekynge ny diuisor there, whiche I fynde ones, Therfore set $I 1$ in the nether lyne. $M$. Not in the 16 nether line of the hole summe, but in the nether lyne of that worke, whiche is the thyrde lyne. $S$. So standeth it with reason.

2 1.8 a. M. Then thas do they stande. Then seke $I$ agayne in the reste, how fynde my diuisor, and I se that in the $300 \mathrm{I}$ myghte fynde 100 thre tymes, but then the 60 wyll not he so often founcle in 20 , therfore I take 2 for my quotient: then take I 100 twyse from 300 , and there resteth 100 , out of whiche with the 20 (that maketh 24 120) I may take 60 also twyse, and then standeth the nombers thus,

31288.

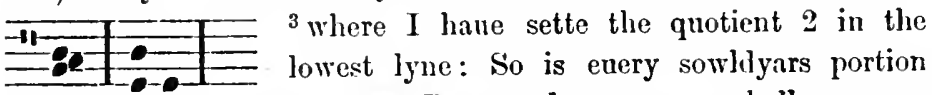
$102 \mathrm{~d}$ '. that is $8 \mathrm{~s} .6 \mathrm{l}$. $M$. But yet bycause you shall perceaue 28 iustly the reason of Diuision, it shall be good that you do set your diuisor styll agaynst those nombres from whiche you do take it: as by this example $I$ wyll declare. Yf $y^{\mathbf{e}}$ purchace of 200 acres of ground dyd coste 290 l'i. what dyd one acre coste? Fyrst 32 wyl I turne the poundes into pennes, so wyll there be $69600 \mathrm{~d}$ '. Then in settynge downe these nombers $I$ shall do thus. Fyrst set the diuident on the rygrite hande as it oughte, and then

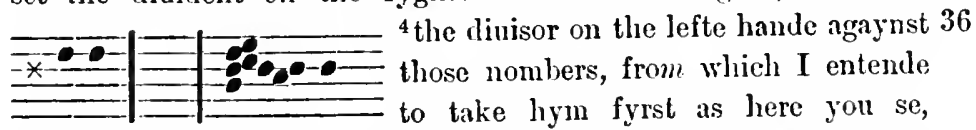

wher I haue set the diuisor two lynes hygher then is theyr owne place. $S$. This is lyke the order of diuision by the penne. 40 
II. Truth you say, and nowe must I set $y^{e}$ quotient of this worke in the thyrde lyne, for that is the lyne of rnities in respecte to the dinisor in this worke. Then I seke howe often the clinisor 4 maye be founde in the diuident, and that 1 fynde 3 tymes, then set $I 3$ in the thyrde lyne for the quotient, and take awaye that 60000 from the dinident, and farther I do set the dinisor one line lower, as yow se here.

8 'And then seke I how often the

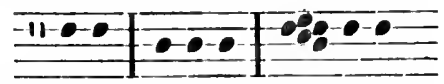
dinisor wyll be taken from the nomber agajnste it, whiche wyll be 4 tymes and 1 remaynynge. S. But what $y f$ it chaunce that when the diuisor is so remoued, it can not be ones taken ont of the

12 ditident agaynste it? $\boldsymbol{M}$. Then must the diuisor be set in an other line lower. S. So was it in dinision by the penne, and therfore was there a eypher set in the quotient: but howe shall that be noted here? M. Here nedeth no token, for the lynes do

16 represente the places: onely loke that you set your quotient in that place which standeth for vnities in respecte of the dinicor: but now to returne to the example, I fynde the diuisor 4 tymes in the dinitente, and 1 remaynynge, for 4 tymes 2 make 8 , which I take

20 from 9 , and there resteth 1 , as this figure sheweth: and in the mydlle space for the quotient $I$ set 4 in the seconde lyne, whiche is in this worke the place of vnities. ${ }^{2}$ Then remone I $y^{e}$ diuisor to the next

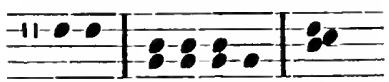
$2130 \%$

24 lower line, and seke how often I may haue it in the dyuident, which I may do here 8 tymes iust, and nothynge remayne, as in this fourme, the hole quoti$2829 \mathrm{~s}$. wherby I knowe that so moche coste the purchace of one aker. S. Now resteth the profes of Multiplycation, and also of Dinision. M. Ther best profes are eche. ${ }^{3}$ one ly the other, for ${ }^{3} 130 \%$ Multyplication is proued ly Diuision, and Diusion by Multiplyea32 tion, as in the worke by the penne you learned. S. Y' that be all, you shall not nede to repete agayue that, $\mathrm{y}^{\mathrm{t}}$ was sufficyently taughte all redye: and excepte you wyll teache me any other feate, here maye yon make an ende of this arte I suppose. M. So $36 \mathrm{wyll}$ I do as touclynge hole nomber, and as for broken nomber, I wyll not trouble your wytte with it, tyll you hane practised this so well, $\mathrm{y}^{\mathrm{t}}$ you be full perfecte, so that you nede not to doubte in any poynte that I haue tanght you, and themne maye I boldly 40 enstruete you in $y^{e}$ arte of fractions or broken nomber, wherin I 
wyll also showe yon the reasons of all that you haue nowe learnel. But yet hefore I make an ende, I wyll showe you the order of commen castyng, wher in are bothe pennes, shyllynges, and poumles,

1 131 a. procedynge by no grounded reason, but onely by a receauel Merchants' ' fourme, and that dyuersly of dyuers men: for marchauntes vise casting. one fourme, and auditors an other: But fyrste for marchauntes fourme marke this example here, expressed this summe 198 ''i. $^{2} 19 \mathrm{~s}$. you maye se that the lowest lyne seructh for pennes, the next aboue for shyllynges, the thyrile for poundes, and the fourth for scores of poumles. And firther you maye se, that the space betwene pennes and shyllynges may receaue but one 12 comiter (as all other spaces lyke wayes (lo) and that one standeth in that place for $6 \mathrm{~d}$ '. Lyke wayes betwene the shyllynges am the pounles, one counter standeth for $10 \mathrm{~s}$. And hetwene the poundes and $20 \mathrm{l}$ i. one comter standeth for 10 pommles. But 16 besycle those you maye see at the left syde of shyllynges, that one ${ }^{3} 131 \mathrm{~s}$. counter standeth alone, and hetokeneth $5 \mathrm{~s}$. 'So agaynste the poundes, that one counter standeth for $5 \mathrm{l}$ 'i. And agaynst the 20 poundes, the one counter standeth for 5 score poumles, that is 20 100 li. so that euery syde counter is 5 tymes so moch as one of them agaynst whiche he stancleth. Now for the accompt of auditors take this example. expressed $\mathbf{y}^{\mathbf{e}}$ same

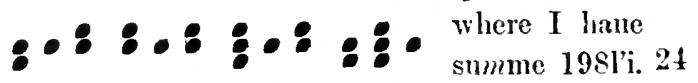
19 s. 11 d'. But here you se the pemes stande towarl y rycht lande, and the other encreasynge orderly towarde the lefte hande. Agayne you maye se, that anditours wyll make 2 lynes (yea and more) for pennes, shyllynges, and all other valewes, yf theyr 28 summes extende therto. Also you se, that they set one counter at the ryght ende of eche rowe, whiche so set there standeth for 5 of

- 132 $a$. that roume: and on ${ }^{4}$ the lefte corner of the rowe it standeth for 10 , of $y^{e}$ same row. But now yf you wold adde other subtracte 32 after any of both those sortes, yf you marke $y^{e}$ orter of $y^{t}$ other feate which I taught you, you may easely do the same here without moch teachynge: for in Addition you must fyrst set lowne one summe and to the same set the other orderly, and lyke maner yf 36 you have many: but in Subtraction you nust sette downe fyrst the greatest summe, and from it must you abate that other enery denomination from his dewe place. S. I do not doubte but with a 2168 in original. 
lytell practise I shall attayne these bothe: but how shall I multiply and diuide after these fourmes? $\boldsymbol{M}$. You can not duely do none of both by these sortes, therfore in suche ease, you must resolt to 4 your other artes. S. Syr, yet I se not by these sortes how to expresse hundreddes, $y \mathrm{f}$ they excede one hundred, nother yet thousandes. $M$. They that vse such accomptes that it excede 200 ${ }^{1}$ in one summe, they sette no 5 at the lefte hande of the scores of $132 b$.

8 poundes, but they set all the hundredes in an other farther rowe and 500 at the lefte hand therof, and the thousandes they set in a farther rowe yet, and at the lefte syde therof they sette the 5000, and in the space oner they sette the 10000 , and in a hygher rowe

1220000 , whiche all I haue expressed in this example, which is 978691 'i. $12 \mathrm{~s}$. 9d' ob. q. for I had not told you before where, nother how you shuld set downe farthynges, which (as you se here) must be set in a voyde space

16 sydelynge beneth the pennes: for q one counter: for ob. 2 counters: for ob. q. 3 comnters: aml more there ean not be, for 4 farthynges 'alo make

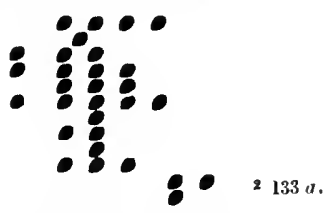
$1 \mathrm{~d}$. which must be set in his dewe place. And yf you desyre $20 \mathrm{y}^{\mathrm{e}}$ same summe after audytors maner, lo here it is.

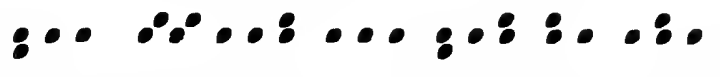

But in this thyng, you shall take this for suffycyent, and the reste you shall obserue as you maye se by the working of eche sorte: for the dyuers wittes of men have inuented dyuers and sundry wayes 24 almost vnnumerable. But one feate I shall teache you, whiche not only for the straungenes aud secretnes is moche pleasaunt, but also for the grood commoditie of it ryghte worthy to be well market. This feate hath ben rsed aboue 2000 yeares at the leaste, and yet 28 was it nener comenly knowen, especyilly in Enjlysshe it was never taughte yet. This is the arte of nombrynge on the hand, with diners gestures of the fyngers, expressynge any summe conceaued in the ${ }^{3}$ mynde. And fyrst to begynne, yf you wyll expresse

32 any summe vnder 100, you shall expresse it with your lefte hande: aud from 100 vnto 10000, you shall expresse it with your ryght hande, as here orderly by this table folowynge you may perceaue.

\section{Here foloweth the table of the arte of the}

hande 
The arte of rrombrungre bug the bुanoc.

134

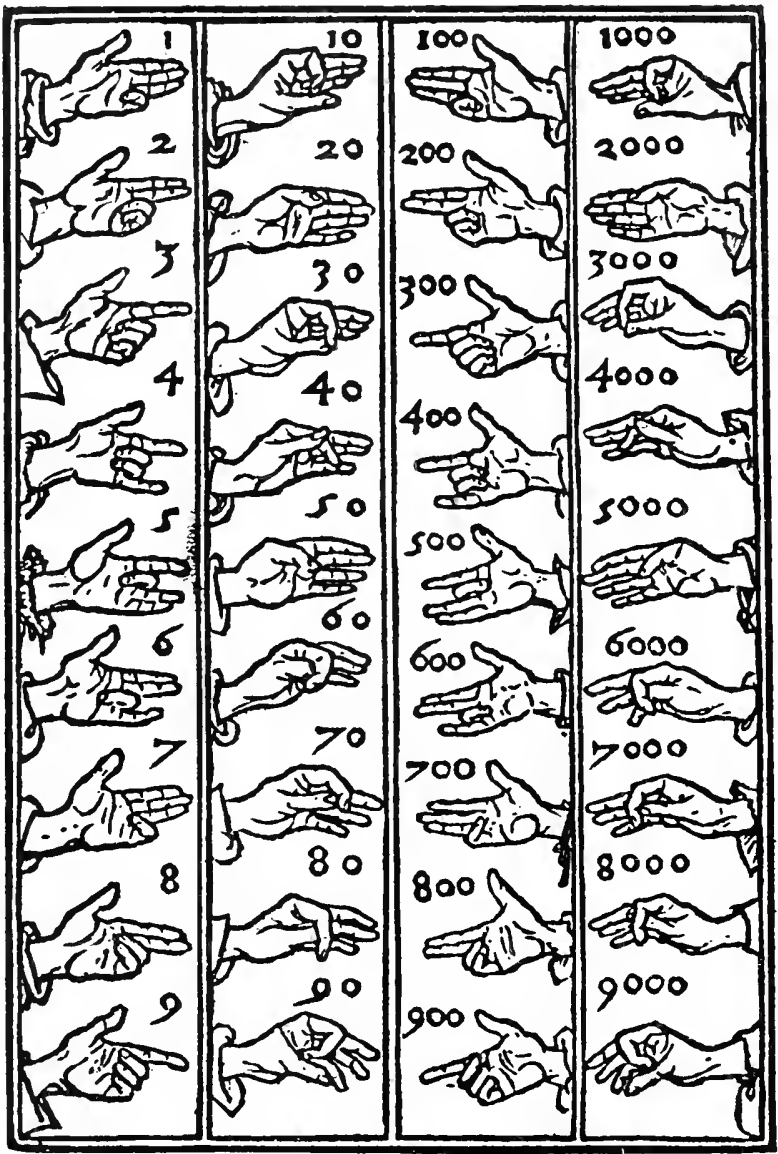

1 1346. $1^{1}$ In which as you may se 1 is expressed by $y^{e}$ lyttle fynger of $y^{e}$ 2 lefte hande closely and harde croked. * 2 is declared by lyke bowynge of the weddynge fynger (whiche is the nexte to the lyttell 3 fynger) together with the lytell fynger. [3 is signified hy the 4 mydlle fynger bowed in lyke maner, with those other two. [4 is declared by the bowyng of the myddle fynger and the rynge * Bracket ([) denotes new paragraph in original. 
fynger, or weddynge fynger, with the other all stretched forth.

[ 5 is represented by the myddle fynger onely bowed. [And 6 hy s, 6

the wedlynge fynger only erooked: and this you maly marke in

4 these a certayne order. but now 7,8 , and 9 , are expressed with the bowynge of the same fyngers as are 1, 2, and 3, but after an other fourme. [For 7 is declared by the bowynge of the lytell, fynger, as is 1 , sane that for 1 the fynger is clasped in, harde and $8{ }^{1}$ rommle, but for to expresse 7 , you shall bowe the myildle ioynte of the lytell fynger only, and holde the other ioyntes streyght. $S$. If you wyll grene me lete to expresse it after my rude maner, thus I vuderstand your meanyng: that 1 is expressed by crookynge

12 in the lyttell fynger lyke the head of a bysshoppes bagle: and 7 is declared by the same fynger bowed lyke a gybbet. M. So I pereenue, you vinderstande it. [Then to expresse 8 , you shall bowe 8 after the same maner both the lyttell fynger and the rynge fynger.

16 [And yf you bowe lyke wayes with them the myddle fynger, then doth it betolien 9. [Now to expresse 10, you shall bowe your 9, 10 fore fyuger rounde, and set the ende of it on the hygliest ioynte of the thombe. [And for to expresse 20, you must set your fyugers 2 , 20 streyglit, and the ende of your thombe to the partition of the 2 fore ${ }^{2} 135 \%$ moste and myddle fynger. [30 is represented by the ioynynge 30 together of $y^{\mathrm{e}}$ lieadles of the foremost fynger and the thombe. [40 is declared liy settynge of the thombe erossewayes on the fore- 10 24 most fynger. $\quad 50$ is signified by ryght stretchyng forth of the 50 fyugers ioyntly, and applyenge of the thombes ende to the pratition of the myddle fynger and the rynge fynger, or wedlynge fynger. [60 is formed by bendynge of the thombe croked and erossynge it 60 28 with the fore fynger. [70 is expressed ly the bowyuge of the io foremost fynger, and settynge the ende of the thombe between the 2 foremost or hygliest ioyntes of it. [80 is expressed by settynge sn of the foremost fynger crossewayes on the thombe, so that 80 32 dyffereth thus from 40 , that for 80 the forefynger is set crosse on the thombe, and for 40 the thombe is set crosse oner $y^{\mathrm{e}}$ forefinger. ${ }^{3}$ [90 is signified, by bendynge the fore fynger, and settyng the culde $90 \quad 3136 a$. of it in the innermost ioynte of $y^{e}$ thombe, that is enen at the foote 36 of it. And thus are all the nombers ented vmder 100. S. In dede these be all the nombers from 1 to 10 , aml then all the tenthes within 100 , but this teacyed me not how to expresse 11,11 12,13 , etc. $21,22,23$, etc. and such lyke. $M$. You can lytell $12,13,21,22$, 40 vuderstande, yf you can not do thit without tenchynge: what is 
$11 ?$ is it not 10 and $1 ?$ then expresse 10 as you were taught, and 1 also, and that is 11 : and for 12 expresse 10 and $2:$ for 23 set 20 and 3: and so for 68 you muste make 60 and there to 8 : and so 100 of all other sortes. [But now yf you wolde represente 100 other 4

any nomber aboue it, you muste do that with the ryghte hande, after this maner. [You must expresse 100 in the ryght hand, with the lytell fynger so bowed as you dyd expresse 1 in the left hand.

${ }_{1}^{1} 136 \mathrm{~b}$ ] [And as you expressed 2 in the lefte hancle, the same fasshyon $2(m)$ in the ryght hancle doth declare 200.

300 The fourme of 3 in the ryght hand standeth for 300 .

400 The fourme of 4 , for 400 .

500 Lykewayes the fourme of 5 , for 500 .

600 The fourme of 6 , for 600 . And to be shorte: loke how you did expresse single vnities and tenthes in the lefte hande, so must you expresse vnities and tenthes of hundredes, in the ryghte hande. 16 $900, S$. I vnderstande you thus: that $y^{\text {f } ~ I ~ w o l d ~ r e p r e s e n t ~} 900$, I must so fourme the fyngers of my ryghte hande, as I shuld do in my left hand to expresse 9, And as in my lefte hand I expressed 100010 , so in my ryght hande must $I$ expresse 1000.

And so the fourme of enery tenthe in the lefte hande serueth to expresse lyke nomber of thousandes, so $y^{e}$ fourme of 40 standeth 4000 for 4000 .

s000 The fourme of 80 for 8000 .

${ }^{2}$ And the fourme of 90 (whiche is the greatest) for 9000 , and aboue that I can not expresse any nomber. $\boldsymbol{M}$. No not with one fynger: how be it, with dyuers fyngers you maye expresse 9999 , and all at one tyme, and that lac keth but 1 of 10000 . So that vnder 10000 you may by your fyngers expresse any summe. And this shal suffyce for Numeration on the fyngers. And as for Addition, Subtraction, Multiplication, and Diuision (which yet were neuer taught by any man as farre as I do knowe) I wyll enstruct you after the treatyse of fractions. And now for this tyme fare well, 
Digital Numeration.

and loke that you cease not to practyse that you haue lear ned. S. Syr, with moste harty mynde I thanke you, bothe for your good learnyng, and also your good

8 counsel, which (god wyllyug) I truste to folow.

Finis. 


\title{
APPENDIX I.
}

\section{A cercatise on the êclumeration of galnorisnt.}

\author{
[From a MS. of the 14 the Century.]
}

To alle suche even nombrys the most have cifrys as to ten. twenty. thirty. an hundred. an thousand and suche other. but ye schal vnderstoncle that a cifre tokeneth nothinge but he maketh other the more significatyf that comith after hym. Also ye schal vulerstonde that in nombrys composyt and in alle other nombrys that ben of diverse figurys ye schal beggnne in the ritht sycle and to rekene backwarde and so he schal be wryte as thus-1000. the sifre in the ritht sile was first wryte and yit he tokeneth nothinge to the secunde no the thrille but thei maken that figure of 1 the more signyfieatyf that comith after hem by as moche as he horn oute of his first place where he schuld yf he stode ther tokene but one. And there he stondith nowe in the ferye place he tokeneth 12 a thousind as by this rewle. In the first place lie tokeneth but hymself. In the secuncle place he tokeneth ten times hymself. In the thridde place he tokeneth an hundred tymes himself. In the ferye he tokeneth a thonsand tymes himself. In the fyftye place 16 he tokeneth ten thousand tymes himself. In the sexte place he tokencth an hundred thousand tymes hymself. In the seveth place he tokeneth ten hundred thousand tymes hymself, \&c. And ye schal vuderstond that this worle nombre is partyd into thre 20 partyes. Somme is eally nombre of digitys for alle ben digitys that ben withine ten as ix, viii, vii, vi, v, iv, iii, ii, i. Artieules ben alle thei that mow he devyled into nombrys of ten as $\mathrm{xx}, \mathrm{xxx}$, $x$, and suche other. Composittys be alle nombrys that ben com- 24 ponyd of a digyt and of an articule as fourtene fyftene thrittene aurl suche other. Fonteno is componyd of four that is a digyt 
and of ten that is an articule. Fyftene is componyel of fyre that is a digyt and of ten that is an articule and so of others . . . . . But as to this rewle. In the firste plice he tukeneth hut himself 4 that is to say he tokeneth but that and no more. If that he stonde in the seeunde place he tokeneth ten tymes himself as this figure 2 here 21. this is oon and twenty. This figure 2 stondith in the seeunde place and therfor he tokeneth ten tymes himself and ten 8 tymes 2 is twenty and so forye of every figure and he stonde after another toward the lest syde he schal tokene ten tymes as moche more as he schuhl token and he storle in that place ther that the figure afore him stondeth: lo an example as thus 963 . This 12 figure of foure that hath this schape 4 tokeneth but himself for he stomleth in the first place. The figure of thre that hath this schipe 3 tokeneth ten tyme himself for he stondeth in the secunde place and that is thritti. The figure of sexe that hath this seliape 6 16 tokenth ten tyme more than he schuld and he stole in the place yer the figure of thre stondeth for ther he schuld tokene but sexty. And now he tokeneth ten tymes that is sexe humbril. The figure of nyne that hath this schape 9 tokeneth ten tymes more than he 20 sehulde and he stode in the place ther the figure of 6 stoncleth inne for thame he schuld tokene but nyne hundryd. And in the place that he stondeth inne nowe he tokeneth nine thousand. Alle the hole nombre of these fomre figmrys. Nine thousind sexe humbrid 24 and foure and thritti. 


\section{APPENDIX II.}

\section{Cearmer de Aflgorismon.}

[From a B.M. MS., 8 C. iv., with additions from 12 E. 1 \& Ey. 2622.]

- Hec algorismus ars presens dicitur ${ }^{1}$; in qua

'Talibus Indorum ${ }^{2}$ fruimur his quinque figuris.

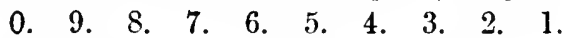

Prima significat unum : duo vero secunda :

Tercia significat tria : sic procede sinistre

Donec ad extremam venies, qua cifra vocatur;

${ }^{3}$ [Que nil significat; dat significare sequenti.]

Quelibet illarum si primo limite ponas,

Simpliciter se significat : si vero secundo,

Se decies: sursum procedas multiplicando. ${ }^{4}$

[Namque figura sequens quevis signat decies plus,

Ipsa locata loco quam significet pereunte:

Nam precedentes plus ultima significabit.]

${ }^{5}$ Post predicta scias quod tres breuiter numerorum

Distincte species sunt; nam quidam digiti sunt;

Articuli quidam; quidan quoque compositi sunt.

[Sunt digiti numeri qui citra denarium sunt;

Articuli decupli degitorum ; compositi sunt

Illi qui constant ex articulis digitisque.]

Ergo, proposito numero tibi scribere, primo

Respicias quis sit numerus; quia si digitus sit, ${ }^{5}$ [Una figura satis sibi ; serl si compositus sit,]

Primo scribe loco digitum post articulum fac

Articulus si sit, cifram post articulum sit,

[Articulum vero reliquenti in scribe figure.]

I "Hec presens ars dicitur algorismus ab Algore rege ejus inventore, vel dicitur ab algos quod est ar's, et rolos quorl est numerus; que est ars numerorum vel numerandi, at yuam artem bene scieudum inveniebantur apul Indos lis quinque (icl est decen) figure."-Comment. Thome de Noto-Mercutu. MS. Bib. lier. Mlus. Brit. 12 E. 1.

2 "Hie necessarie firure sunt Indorum characteros." WS. de numerctione. Bib. Sloan. Mus. Brit. 513, fol. 58. "C'mm vidissem Yuclos constituisse Ix literas in miverso numero suo propter dispositionem suan quam posuerunt, volui patefacere re opere quod sit per eas aliquidque esset levins discentibus, si Deus voluerit. Si autem ludi hoc voluerunt et intentio illorum nihil novem literis fuit, eansa que mili potnit. Dens direxit me ad hoc. Si vero alia dicam preter eam cuam ego exposui, loc feccrunt per loe quod ego exposui, eadem tan certissime et absque ulla dubitatione poterit invenirj. Levitasque patelit aspicientibus et discentilus." MS. U. L. C., li. vi. 5, f. 102.

3 Froul Eg. 2622.

- 8 C. iv. inserts Nullum cipa significat: dat significare sequeuti.

5 From 12 E. 1. 
Quolibet in numero, si par sit prima ligura, Par erit et totum, quierquid sili continetur;

Impar si fuerit, totum sibi fiet et impar.

Septem ${ }^{1}$ sunt partes, non plures, istius artis ;

Addere, subtrahere, duplare, dimidiare;

Sexta est diuidere, set quintil est multiplicare;

Ralicem extrahere pars septima dicitur esse.

Subtrahis aut arldis a dextris vel mediabis;

$\Lambda$ lena dupli, diuide, multipliearue;

Extrahe mlicem semper sub parte sinistra.

Adlere si numero numerum vis, ordine tali

Incipe; seribe duas primo series numerorum

Prima sub prima recte ponendo figuram,

Et sic de reliquis facias, si sint tibi plures.

Inde cluas adle primas laac condicione;

Si digitus crescat ex aldicione priorum,

P'rimo scribe loco digitum, quicunque sit ille;

Si sit compositus, in limite seribe sequenti

Articulum, primo digitum; quia sic inbet ordo.

Articulus si sit, in primo limite cifram,

Articulum vero relipuis inseribe figuris;

Vel per se scribats si nulla figura sequatur.

Si tibi eifra superueniens occurrerit, illam

Deme suppositam ; post illie scribe figuram :

Post a procediss reliquas adilendo figuras.

A numero numerum si sit tili demere cura,

Seribe figurarum series, vt in addicione;

Maiori numero numerum suppone minorem,

Sine pari numero supponatur numerus par.

Postea si possis a prima subtrahe primam,

Seribens ruod remanet, cifram si nil remanelit.

Set si non possis a prima demere primam;

Procedens, vnum de limite deme sequenti;

1 Eu argorisme devon prendre

Vii especes

Alision subtracion

Donbloison mediacion

Monteploie at division

Et de ratix enstracion

A chez vii espreces savoir

Doit chaseun en memoire aroir

Letres qui firrures sont lites

Et qui excellens sont eerites.-MS. Sill. Arch. B. 26. 
Et demptum pro denario reputabis ab illo,

Subtrahe totaliter numerum quem proposuisti.

Quo facto, scribe supra quicquit remanebit,

Facque novenarios de cifris, cum remanebis,

Occurrant si forte cifre, dum demseris vnum ;

Postea procedas reliquas demendo figuras.

Proof. ' [Si subtracio sit bene facta probare valebis,

Quas subtraxisti primas addendo figuras.

Nam, subtractio si bene sit, primas retinebis,

Et subtractio facta tibi probat additionem.]

Duplation. Si vis duplare numerum, sic incipe; solam

Scribe figurarum seriem, quamcumque voles que

Postea procedas primam duplando figuram;

Inde quod excrescet, scribens, vbi iusserit ordo,

Juxta precepta que dantur in addicione.

Nam si sit digitus, in primo limite scribe;

Articulus si sit, in primo limite cifram,

Articulum vero reliquis inscribe figuris;

Tel per se scribas, si nulla figura sequatur:

Compositus si sit, in limite scribe sequenti

Articulum primo, digitum; quia sic jubet ordo:

Et sic de reliquis facias, si sint tili plures.

1 [Si super extremam nota sit, monalem dat eidem,

Quod tibi contingit, si primo dimidiabis.]

Mediation. Incipe sic, si vis aliquem numerum mediare:

Scribe figurarum seriem solam, velud ante;

Postea procelens melias, et prima figura

Si par aut impar videas; quia si fuerit pas,

J)imidiabis eam, scribens quicquit remanclit;

Impar si fuerit, vmun demas, mediare,

Nomne presumas, sed quod superest mediabis;

Inde super tractum, fac demptum quod notat unum;

Si monos, lele; sit ibi cifra post nota supra.

Postea procedas hac condicione secunda : ${ }^{2}$

Impar $^{3}$ si fuerit lic vnum deme priori,

Inscribens quinque, nam denos significalbit

Monos preelictan ; si vero secunda dat vnam,

Illa deleta, scribatur cifra; priori

1 From 12 E. 1.

$28 \mathrm{C}$. iv. inserts Atque figura prior nuper fuerit mediando.

3 I. e. figura secundo loco posita. 
Tradendo quinque pro denario mediato;

Nec eifra scribatur, nisi inde figura sequatur :

Postea procdeas reliquas mediando figuras,

Quin supra docui, si sint tibi mille figure.

1 [Si mediatio sit bene faeta probare valebis,

Juplando numerum quem primo dimicliasti.]

Si tu per numerum numerum vis multiplicare,

Scribe duas, quascunque volis, series numerorum ;

Orlo tamen seruetur vt vltima nultiplicandi

Ponatur super anteriorem multiplicantis;

2 [A lena relique sint scripte multiplieantes.]

In digitum eures digitum si dncere, major

108

Per yuantes distat a denis respice, debes

Namyue sno decuplo tociens delere minorem;

Sicque tibi numerus veniens exinde patebit.

lostea procerlas postremam multiplicando,

Juste multiplicans per cunctas inferiores,

Condieione tamen tali ; quod multiplieantis

Serilas in capite, quicyuil processerit incle;

Set postyuam fuerit hec multiplicata, figure

Anteriorentur serici multiplicantis ;

Et sic multiplica, velut istam multiplicasti, Qui sequitur numerum seriptum quicmulue figmis.

Set cum multiplicas, primo sic est operandum,

Si dabit articulum tibi multiplicacio solum;

Proposita cifra, summam transferre memento.

Sin autem digitus excrescerit articulusque,

Articulns supraposito digito salit ultrn;

Si digitus tamen, ponas illum super ipsam,

Subdita multiplicans hane que super incilit illi

Delet eam penitus, scribens quod provenit inde;

Sed si multiplices illam posite super ipsam,

Adinngens numerum quem prebet duetus earum;

Si supraimpositam eifra debet multiplicare,

Prorsus eam delet, scribi que loco cifra debet,

2 [Si eifra multiplicat aliam positam super ipsam,

Sityue locus supra vacuus super hane cifra fiet ;]

So 12 E. 1 ; 8 C. iv. inserts-

Si super extremam nota sit monades dat eidem

Quod contingat cum primo limiabis

212 E. 1 inserts.

Atque figura prior nuper fuerit mediando. 
Si supra fuerit cifra semper pretereunda est ;

Si dubites, an sit bene multiplicaudo secunda,

Diuide totalem numerum per multiplicantem,

Et reddet numerus emergens inde priorem.

Mental

${ }^{1}$ [Per numerum si vis numerum quoque multiplicare

tion.

Tantum per normas subtiles absque figuris

Has normas poteris per versus scire serjuentes.

Si tu per digitum digitum quilibet multiplicabis

Regula precedens dat qualiter est operandum

Articulum si per reliquum vis multiplicare

In proprium digitum debebit utergue resolvi

Articulus digitos post per se multiplicantes

Ex digitis quociens teneret multiplicatım

Articuli faciunt tot centum multiplicati.

Articulum digito si multiplicamus oportet

Articulum digitum sumi quo multiplicare

Debemus reliquum quod multiplicaris ab illis

Per reliquo decuplum sic omne latere nequilit

In numerum mixtum digitum si ducere cures

Articulus mixti sumatur deinde resolvas

In digitum post hec fac ita de digitis nee

Articulusque docet excrescens in detinendo

In digitum nixti post ducas multiplicantem

De digitis ut norma docet sit juncta secunlo

Mfultiplica summam et poster summa patelit

Junctus in articulum purum articulumque

2 [Articulum purun comittes articulum que]

Mixti pro dicritis post fiat et articulus vt

Norma jubet retinendo (quod egreditur al, illis

Articuli digitum post iu digitum mixti due

Regrula de digitis ut percipit articulusque

Ex quibus excrescens summe tu junge priori

Sic manifesta cito fiet tili summa petita.

Compositum numerum mixto sic multiplicalis

Vndecies tredecem sic est ex hiis operandum

In reliyuum primum demum duc post in eundem

Unum post deinde duc in tercia deinde per unum

Multiplices tercia demum tunc omnia nultiplicata

In summa duces quam que fuerit te dices 
Hic ut hic mixtus intentus est operandum

Multiplicandorum de normis sufficiunt hee.]

Si vis divilere numerum, sic ineipe primo;

Division.

Scribe duas, quascunque voles, series numerorum ;

Majori numero numerum suppone minorem,

${ }^{1}$ [Nam docet ut major teneat bis terve ninorem;]

Et sub supprina supprimam pone figuram,

Sic reliquis reliquas a dextra parte locabis;

Postea de prima primam sub parte sinistra

Subtrahe, si possis, quociens potes adminus istud,

Seribens quod remanet sub tali conditione;

Ut totiens demas demendas a remanente,

Que serie recte ponentur in anteriori,

Unica si, tantum sit ibi decet operari;

Set si non possis a prima demere primam,

Procedas, et eam numero suppone sequenti ;

Hanc uno retrahendo gradu quo comites retrahantur,

Et, quotiens poteris, ab eadem deme priorem,

Ut totiens demas demendas a remanenti,

Nec plus quam novies quicquam tibi demere debes,

Naseitur hine numerus quociens supraque sequentem

Hunc primo seribas, retrihas exinle figuras,

Dum fuerit major supra positus inferiori,

Et rursum fiat divisio more priori;

Et numerum quotiens supra seribas pereunti,

Si fiat saliens retrahendo, cifra locetur,

Et pereat numero quotiens, proponas eidem

Cifram, ne numerum pereat vis, dım loeus illic

liestat, ex expletis divisio non valet ultra :

I)

Illum servabis; hinc multiplicande probalis,

Si bene fecisti, divisor multiplicetur

I'er numerum quotiens; cum multiplieaveris, adde

Totali summe, quod servatum fuit ante,

Reddeturque tibi numerus quem proposuisti;

Et si nil remanet, hune multiplieando reddet,

Cum ducis numerum per se, qui provenit inde

Sit tibi quadratus, ductus radix erit hujus,

Nec numeros onnes quadratos dicere debes,

Est autem omnis numerus radix alicujus. 
Quando voles numeri radicem querere, scribi Debet; inde notes si sit loeus ulterius intpar, Estque figura loco talis scribenda sub illo, Que, per se dicta, numcrum tibi destruat illum,

Vel quantum poterit ex inde delebis eandem;

Vel retrabendo duples retriliens duplando sub ista

Que primo sequitur, duplicatur per duplacationem,

Post per se minuens pro posse quod est minuendum.

1 Post his propones digitum, qui, more priori

Per precedentes, post per se multiplicatus,

Destruat in quantum poterit numerum remaueutem,

Et sie procedens retralıens duplando figuram,

Preponesilo novam donec totum peragatur,

Subdupla propriis servare docetque duplatis;

Si det compositum numcrum duplacio, debet

Inseribi digitus a parte dextra parte propinqua,

Articulusque loco quo non duplicata resessit;

Si dabit articulum, sit cifra loco percunte

Articulusque locum tenet unum, de duplicata resessit;

Si donet digitum, sub prima pone scquente,

Si supraposita fuerit duplicata figura

Major proponi acbet tantummorlo cifra,

Has retralıens solito propones more figuram,

Usque sub extrema ita fac retrahendo figuras,

Si totım deles numerum quem proposuisti,

Quadratus fuerit, de dupla quod duplicasti,

Sicque tibi radix illius certa patebit,

Si de duplatis fit juncta supprima figura;

Radicem per se multiplices habeasque

Primo propositum, bene te fecisse probasti ;

Non est quadratus, si quis restat, sed habentur

Radix quadrati qui stat major sub eadem ;

Vel quicquid remanet tabula servare memento;

Hoc casu radix per se quoque multiplicetur,

Vel sic quadratus sub primo major habetur,

Hine addas remanens, et prius debes haberi;

Si locus extremus fuerit par, scribc figuram

Sub pereunte loco per quam debes operari,

Que quantum poterit supprimas destruat ambas,

18 C. iv. inserts-

Hine illam dele duplans sub ei psalliendo

Que sequitur retrahens quicquid fuerit duplicatum. 
Vel penitus legrem teneas operando prioren,

Si suppositum eligitus suo fine repertus,

Ommino delet illic scribi cifra debet,

A levi si fua sit ei sociata figura;

Si cifre remanent in fine pares decet harum

Ratices, numero mediam proponere partem,

Tali quesita radix patet arte reperta.

- Per numerum recte si nosti multiplicare

Ejus quadratum, numerus qui pervenit incle

Dicetur cubicus; primus radix erit ejus ;

Nec numeros omues cubicatos dicere lebes,

Est autem ommis numerus radix alicujus;

Si curas cubici ralicem quarere, primo

261 Cube Root.

Inscriptum numerum distinguere per loca debes;

(cue tibi mille notant a mille notante suprema

Initiam, summa operandi parte sinistra,

Illie sul, seribas dicritum, qui multiplicatus

In semet eubice suprapositum sibi perdat,

Et si quid fuerit adjunctum parte sinistra

Si non omnino, quantum poteris minuendo,

Hinc triplans retrahe saltum, facienclo sub illa

Que manet a digito deleto terna, figuram

Illi propones que sub triplo asocietur,

Ut cum subtriplo per eam tripla multiplicatur;

Hine per eam solam productum multiplieabis,

Pustea totalem numerum, qui provenit inde

A suprapositis respectu tolle triplate

Adrlita supprimo cubice tunc multiplicetur,

liespectu eujus, numerus qui progredictur

Ex cubito ductu, supra onmes alimetur ;

Tunc jpsam delens triples saltum faciendo,

Semper sub termas, retrahens alias triplicatas

Ex line triplatis aliam propone figuram,

Que per triplatas ducatur more priori ;

Primo sub triplis sibi junctis, postea per se,

In numerum ducta, proluctum de triplicatis :

Utque prius dixi numerus qui provenit inde

A suprapositis las respiciendo trahatur,

Inic cubice ductum sub primo multiplicabis,

Respectumyue sui, removebis de remanenti,

Et sic procedas retrahendo triplando figuram. 
Et proponendo nonam, donec totum peragitur, Subtripla sub propriis servare decet triplicatis ;

Si nil in fine remanet, numerus datus ante

Est cubicus; cubican radicem sub tripla prebent,

Cum digito juncto quem supprimo posuisti,

Hec cubice ducta, numerum redelant tibi primum.

Si quid erit remanens non est cubicus, sed habetur

Major sub primo qui stat radix cubicam,

Servari debet quicquid ralice remansit,

Extracto numero, decet hec addi cubicato.

Quo facto, numerus reddi debet tibi primus.

Nam debes per se radicem multiplicare

Ex hinc in numerum duces, qui provenit inde

Suls primo cubicus major sic invenietur;

Illi jungatur remanens, et primus habetur,.

Si per triplatum numerum nequeas operari;

Cifram propones, nil vero per hanc operare

Set retrahens illam cum saltu deinde triplata,

Propones illi digitum sub lege priori,

Cunque cifram retrahas saliendo, non triplicaljis,

Namque nilil cifre triplacio dicitur esse;

At tu cum cifram protraxeris aut triplicata,

IIanc eum subtriplo semper scrvare memento:

Si det compositum, digiti triplacio debet

Illius scribi, digitus saliendo sub ipsam;

Digito deleto, que terna dicitur esse;

Jungitur articulus cum triplata percunte,

Set facit hunc scribi per se triplacio prima,

Que si det digitum per se scribi facit illum;

Consumpto numero, si sole fuit tibi cifre

Triplato, propone cifram saltum faciendo,

Cumque cifram retrahe triplam, scribendo figuram,

Preponas cifre, sic procedens operare,

Si tres vel duo serie in sint, pone sub yma,

A dextris digitum servando prius documentum.

Si sit continua progressio terminus nuper

Per majus me:lium totalem multiplicato;

Si par, per medium tunc nultiplicato sequentem.

Set si continua non sit progressio finis :

Impar, tunc majus medium si multiplicabis,

Si par per medium sibi multiplicato propinquum. 


\section{INDEX OF TECHNICAL TERMS ${ }^{1}$}

algorisme, $33 / 12$; algorym, augrym, 3/3; the art of computing, using the so-called Arabic numerals.

The word in its various forms is lerived from the Arabic alKhouarami (i.e. the native of Klowaram (Khiva)). 'This was the surmame of Ja'far Moliammad ben Musa, who wrote a treatise early in the 9 th century (see p. xiv).

The form algorithm is also found, being suggested by a supposed derivation from the Greek à $s \theta \mu o ́ s$ (number).

antery, 24/I I ; to move figures to the right of the position in which they are first written. This operation is performed repeatedly upon the multiplier in multiplication, and upon certain figures which arise in the process of root extraction.

anterioracioun, $50 / 5$; the operation of moving figures to the right.

article, $34 / 23$; articul, $5 / 31$; articuls, $9 / 36,29 / 7,8$; a number divisible by ten without remainder.

cast, $8 / 12$; to add one number to another.

'Addition is a custing together of two numbers into one number,' $8 / 10$.

cifre, $4 / 1$; the name of the figure 0 . The word is derived from the Arabic sif $r=$ empty, nothing. Hence zero.

A cipher is the symbol of the absence of number or of zero quantity. It may be used alone or in conjunction with digits or other ciphers, and in the latter case, according to the position which it occupies relative to the other figures, indicates the absence of units, or tens, or hundreds, etc. The great superiority of the Arabic to all other systems of notation resides in the employment of this symbol. When the cipher is not used, the place value of digits has to be indicated by writing them in assigned rows or columns. Ciphers, however, may be interpolated anongst the signiticant figures used, and as they sufticiently indicate the positions of the empty rows or columns, the latter need not be indicated in any other way. The practical performance of calculations is thus enormously facilitated (see p. xvi).

componede, $33 / 24$; composyt, $5 / 35$; with reference to numbers, one compounded of a multiple of ten and a digit.

conuertide $=$ conversely, 46/29, 47/9.

cubicede, $50 / 13$; to be c., to have its cube root found.

1 This Index has been kindly prepared by Professor J. B. Dale, of King's College, University of London, and the best thanks of the Society are due to him for his valuable contribution. 
cublke nombre, $47 / 8$; a number formed by multiplying a given number twice by itself, e.g. $27=3 \times 3 \times 3$. Now called simply a cube.

decuple, $22 / 12$; the product of a number by ten. Tenfold.

departys $=$ divides, $5 / 29$.

digit, 5/30; digitalle, 33/24; a number less than ten, represented by one of the nine Arabic numerals.

dimydicion, $7 / 23$; the operation of dividing a number by two. Halving. duccioun, multiplication, 43/9.

duplacion, $7 / 23,14 / 15$; the operation of multiplying a number by two. Doubling.

l-mediet $=$ halved, $19 / 23$.

intercise $=$ lroken, 46/2; intercise Progression is the name given to either of the Progressions 1, 3, 5, 7, etc. ; 2, 4, 6, 8, etc., in which the common difference is 2 .

lede into, multiply by, $47 / 18$.

lyneal nombre, $46 / 14 ;$ a number such as that which expresses the measure of the length of a line, and therefore is not necessarily the product of two or more numbers (vide Superficial, Solid). This appears to be the meaning of the phrase as used in The Art of Nombryng. It is possible that the numbers so designated are the prime numbers, that is, numbers not divisible by any other number except themselves and unity, but it is not clear that this limitation is intended.

mediacioun, 16/36, 38/16; dividing by two (see also dimydicion).

medlede nombre, $34 / 1$; a number formed of a multiple of ten and a digit (vide componede, composyt).

medye, $17 / 8$, to halve ; mediete, halved, $17 / 30$; ymedit, $20 / 9$.

naturelle progressioun, $45 / 22$; the series of numbers $1,2,3$, etc.

produccioun, multiplication, $50 / 11$.

quadrat nombre, $46 / 12$; a number formed by multiplying a given number by itself, e. $y .9=3 \times 3$, a square.

rote, $7 / 25$; roote, $47 / 11$; root. The roots of squares and cubes are the numbers from which the squares and cubes are derived by multiplication into themselves.

significatyf, significant, 5/14. The significant figures of a number are, strictly speaking, those other than zero, e.g. in 3650400 , the significant figures are $3,6,5,4$. Modern usage, however, regards all figures between the two extreme significant figures as significant, even when some are zero. Thus, in the above example, 36504 are considered significant.

solide nombre, $46 / 37$; a number which is the product of three other numbers, e.g. $66=11 \times 2 \times 3$.

superficial nombre, $46 / 18$; a number which is the product of two other numbers, e.g. $6=2 \times 3$.

ternary, consisting of three digits, $51 / 7$.

vnder double, a digit which has been doubled, $48 / 3$.

vnder-trebille, a digit which has been trebled, $49 / 28$; vnder-triplat, $49 / 39$.

w, a symbol used to denote half a unit, $17 / 33$. 


\section{GLOSSARY}

ablacioun, taking away, 36/2 I

addyst, haddest, $10 / 37$

agregacioun, addition, 45/22. (First

example in N.E.D., 1547.)

a-3enenes, against, 23/10

allgate, always, $8 / 39$

als, as, $22 / 24$

and, if, $29 / 8 ; \&, 4 / 27 ; \& \mathrm{Jf}, 20 / 7$

a-nendes, towards, $23 / 15$

aproprede, appropriated, $34 / 27$

apwereth, appears, $61 / 8$

a.rigy 3 , arises, $14 / 24$

a-rowe, in a row, $29 / 10$

arsemetrike, arithmetic, $33 / 1$

ayene, again, 45/15

bagle, crozier, $67 / 12$

bordare $=$ ordure, row, 43/30

borro, inf. borrow, $11 / 38$; imp. $s$.

borowe, 12/20; pp. borwed, 12/15 ;

borred, $12 / 19$

boue, above, $42 / 34$

caputule, chapter, $7 / 26$

certeyn, assuredly, 18/34

clepede, called, $47 / 7$

competently, conveniently, $35 / 8$

oompt, count, $47 / 29$

contynes, contains, $21 / 12$; $p$. con-

tenythe, $38 / 39$

craft, art, $3 / 4$

distingue, divide, $51 / 5$

egalle, equal, 45/2 I

excep, except, $5 / 16$

exclusede, excluded, $34 / 37$

excressent, resulting, $35 / 16$

exesnt, resulting, $43 / 26$

expone, expound, $3 / 23$ ferye $=$ ferbe, fourth, $70 / 12$

figure $=$ figures, $5 / 1$

for-by, jast, 11/2 I

fors; no f., no matter, $22 / 24$

forseth, matters, $53 / 30$

forye $=$ forpe, forth, $71 / 8$

fyitye $=$ fyftpe, fifth, $70 / 16$

grewo, Greok, 33/13

haluendel, half, $16 / 16$; haldel, $19 / 4$; $p l$. haluedels, 16/16

hayst, hast, $17 / 3,32$

hast, haste, $22 / 25$

heer, higher, $9 / 35$

here, their, $7 / 26$

here-a-fore, heretofore, $13 / 7$

heyth, was called, $3 / 5$

hole, whole, 4/39; holle, $17 / 1$; hoole, of three dimensions, $46 / 15$

holdy pe, holds good, $30 / 5$

how be it that, although, 44/4 .

lede $=$ lete, let, $8 / 37$

lene, lend, $12 / 39$

lest, least, $43 / 27$

lest $=$ left, $71 / 9$

leue, leave, 6/5; pr. 3 s. leues, remains, $11 / 19$; leas, $11 / 28$; $p p$. laft, left, $19 / 24$

lewder, more ignorant, $3 / 3$

lnst, desirest to, $45 / 13$

ly3t, easy, 15/31

lymytes, limits, $34 / 18$; lynes, $34 / 12$; lynees, $34 / 17$; Lat. limes, $p l$. limites.

mayatery, achievement; no m., no achievement, i. o. easy, 19/10

mo, indef. pron. one, $42 / \mathrm{t}$

mo, more, $9 / 16$ 
moder $=$ more (Lat. majorem), 43/22

most, must, $30 / 3$

multipliede, to be $\mathrm{m}$. = multiplying, $40 / 9$

mynotes, the sixty parts into which a unit is divided, $38 / 25$

myse-wro3t, mis-wrought, 14/ I I

nether, nor, $34 / 25$

nex, next, 19/9

no $\mathbf{t}$, nought, $5 / 7$

note, not, $30 / 5$

oo, one, $42 / 20 ; 0,42 / 21$

omest, uppermost, ligher, $35 / 26$; omyit, $35 / 28$

omwhile, sometimes, $45 / 3 \mathrm{I}$

on, one, $8 / 29$

opyne, plain, $47 / 8$

or, before, $13 / 25$

or $=$ pe opcr, the other, $28 / 34$

ordure, order, $34 / 9$; row, $43 / 1$

other, or, $33 / 13,43 / 26$; other...

or, either . . or, $38 / 37$

onerer, upper, $42 / 15$

ouer-hippede, passed over, 43/19

recte, directly, $27 / 20$

remayner, rcmainder, $56 / 28$

representithe, represented, 39/14

resteth, remains, $63 / 29$

rewarde, regard, $48 / 6$

rew, row, $4 / 8$

rewle, row, $4 / 20,7 / 12$; rewele, $4 / 18$; rewles, rules, $5 / 33$

s. $=$ scilicet, $3 / 8$

ventens, meaning, $14 / 29$

signifye(tyf), 5/13. The last thrce letters are added above the line, cridently because of the word 'sig. nificatyf' in 1. 14. But the 'Solucio,' which contained the word, has been omitted.

sithen, since, $33 / 8$

some, sum, result, 40/17, 32

sowne, pronounce, $6 / 29$ singillatim, singly, $7 / 25$

spices, species, kinds, $34 / 4$

apyl, waste, 14/26

styde, stead, 18/20

subtrahe, subtract, 48/12; $p p$. sub.

trayd, 13/2 I

sythes, times, 21/16

ta3t, taught, $16 / 36$

take, $p$. taken; t. fro, starting from, $45 / 22$

taward, toward, $23 / 34$

thou 3 t, though, 5/20

trebille, multiply by threc, $49 / 26$

twene, two, 8/1 I

pow, though, 25/ I 5

pow3t, thought; be b., mentally, 28/4

pas $=$ pis, this, $20 / 33$

vny, unite, 45/10

wol, wilt, 14/31

wete, wit, $15 / 16$; wyte, know, $8 / 38$; pr. 2 s. wost, $12 / 3^{8}$

wex, become, $50 / 18$

where, whether, $29 / 12$

wher-thurghe, whence, $49 / 15$

worch, work, 8/19; wrich, 8/35;

wyrch, $6 / 19$; imp. s. worch, 15/9;

pp. $\mathbf{y}$-wroth, $13 / 24$

write, written, 29/19; $y$-write, 16/1

wryrchynge $=$ wyrchynge, working, $30 / 4$

$w^{t}$, with, $55 / 8$

y-broth, brought, $21 / 18$

ychon, each one, 29/10

ydo, done, added, $9 / 6$

ylke, same, 5/12

y-lyech, alike, $22 / 23$

$y$-my 3 t, been able, $12 / 2$

y-now 3 t, enough, $15 / 3$ i jnov $3 t, 18 / 34$

yove, given, $45 / 33$

$\mathbf{y}^{\mathrm{t}}$, that, $52 / 8$

y-write, $v$. write.

$\mathrm{y} \cdot$ wroth, $v$. worch. 



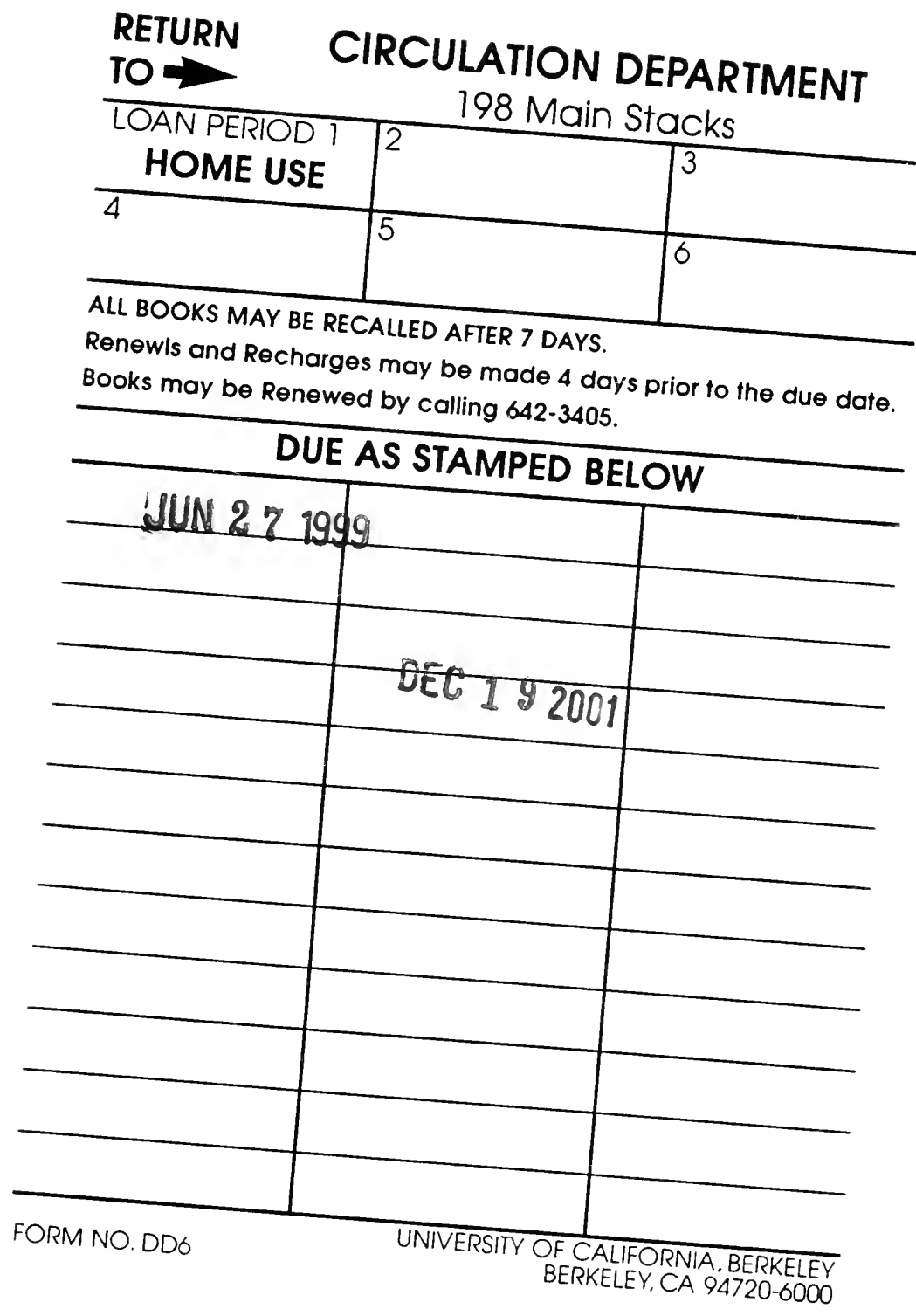




\section{U.C. BERKELEY LIBRARIES}

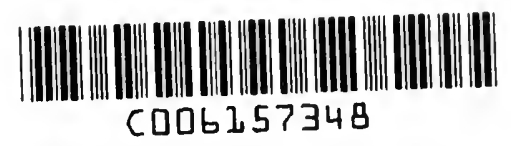




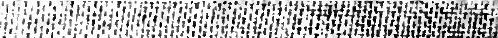

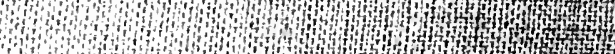

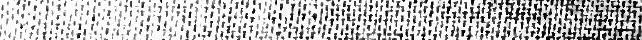

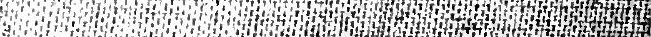

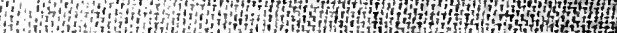

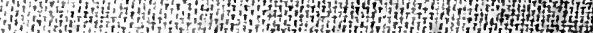
tonitint and (n)

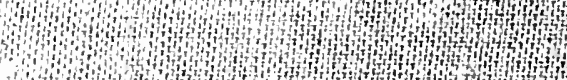

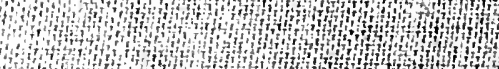

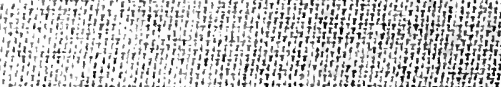

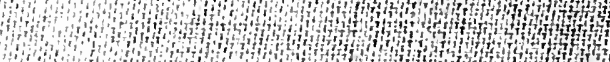

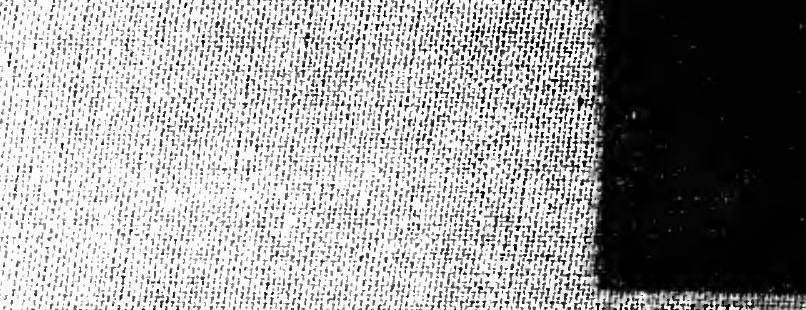

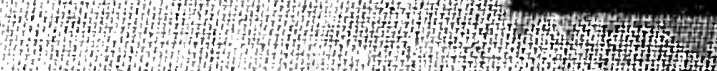

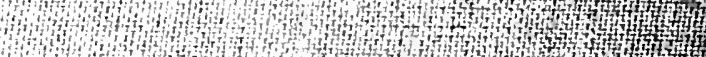

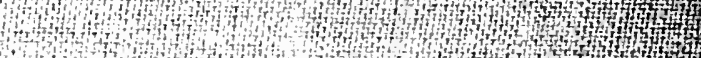

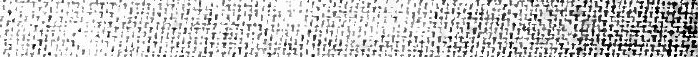

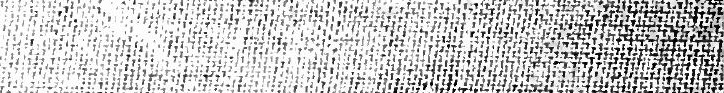

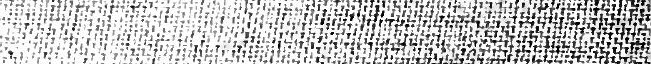

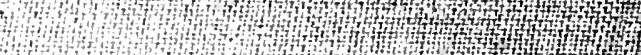

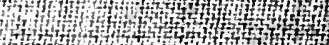

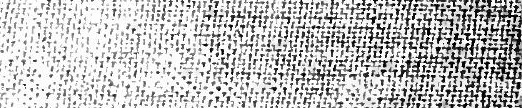

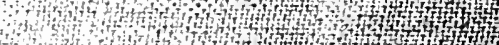

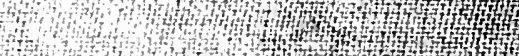

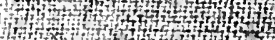

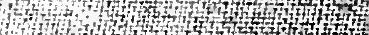
(1, (t)

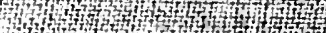
thet

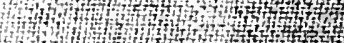

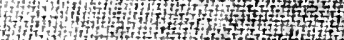
ty

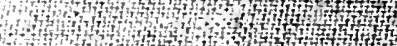

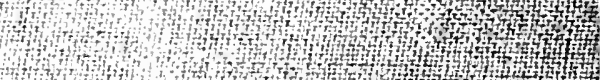

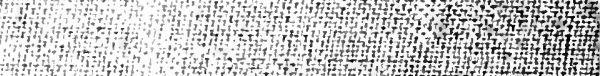

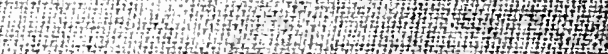
U.7.

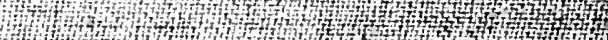

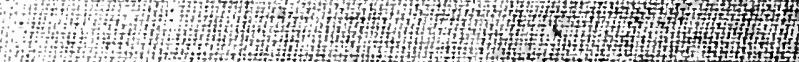
Whith

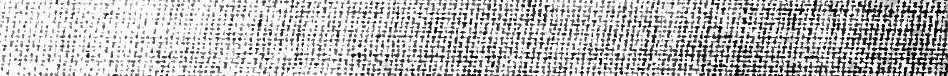

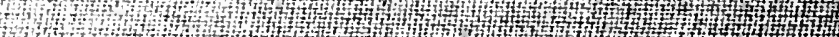

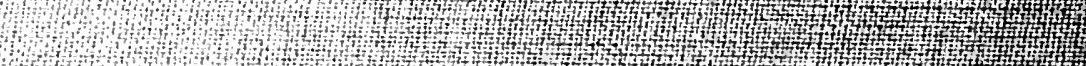

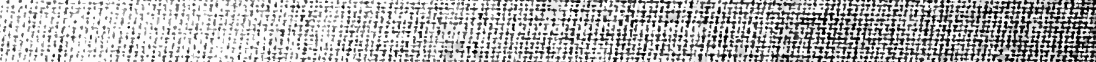

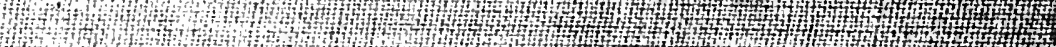
H

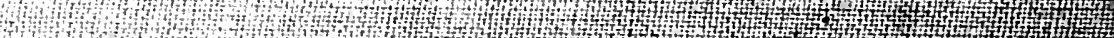

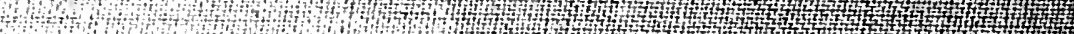

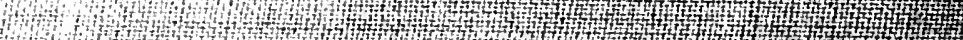

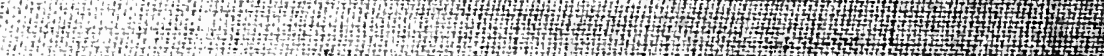

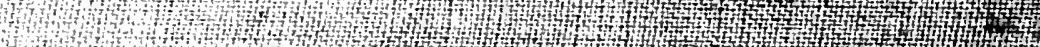

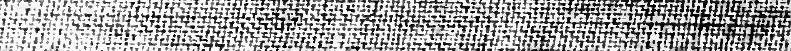

